
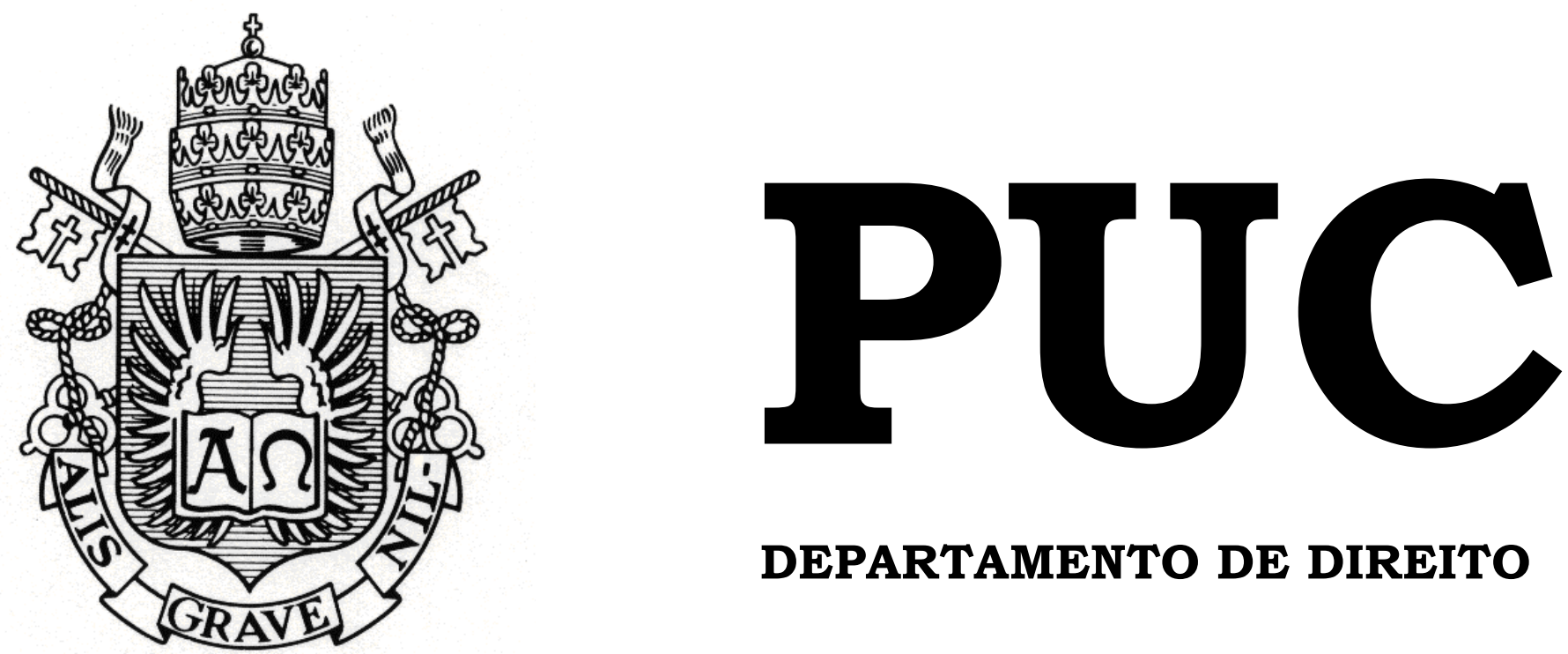

DEPARTAMENTO DE DIREITO

Teoria da Transcendência dos Motivos Determinantes

por

João Moraes Neto

ORIENTADORA: Marianna Montebello Willeman

2011.1

PONTIFÍCIA UNIVERSIDADE CATÓLICA DO RIO DE JANEIRO

RUA MARQUÊS DE SÃO VICENTE, 225 - CEP 22453-900 RIO DE JANEIRO - BRASIL 


\title{
Teoria da Transcendência dos Motivos Determinantes
}

\author{
por \\ JOÃO MORAES NETO
}

Monografia apresentada ao Departamento de Direito da Pontifícia Universidade Católica do Rio de Janeiro (PUC-Rio) para a obtenção do Título de Bacharel em Direito.

Orientadora: Marianna Montebello Willeman 
Dedicada a Milena Hemerly Ferreira, que deixou tantas alegrias quantas saudades. 


\section{Agradecimentos}

A Deus.

Aos meus pais, Afrânio e Janice.

À minha namorada, Maiane.

À minha professora orientadora, Marianna. 


\section{Resumo}

O trabalho busca analisar a teoria da transcendência dos motivos determinantes, aplicada às decisões do STF em controle concentrado abstrato de constitucionalidade.

A teoria da transcendência dos motivos determinantes surgiu nos países da Commom Law. Ela busca justificar a extensão do efeito vinculante, de que são dotadas as decisões do STF em controle concentrado de constitucionalidade, aos motivos que fundamentaram a decisão.

Em princípio, a eficácia erga omnes e o efeito vinculante abrangem somente o dispositivo da sentença. Entretanto, toda decisão judicial traz um holding, que é a norma advinda da interpretação do ordenamento jurídico para a resolução do caso concreto. Essa teoria busca cobrir o holding com o efeito vinculante.

A adoção da teoria serviria para pacificar questões constitucionalmente relevantes para o País, uma vez que, como o efeito vinculante das decisões do STF não estaria limitado ao dispositivo, o Supremo só teria que se pronunciar uma única vez sobre a constitucionalidade de determinada questão e essa decisão abrangeria também outros diplomas normativos com o mesmo conteúdo.

PALAVRAS-CHAVE: controle concentrado abstrato de constitucionalidade, limites objetivos do efeito vinculante e da eficácia erga omnes, extração de uma norma abstrata da decisão (holding), transcendência dos motivos determinantes. 


\section{Sumário}

1. Introdução

2. A importância dos precedentes judiciais no Brasil 11

3. Efeito vinculante, eficácia erga omnes e coisa julgada erga omnes 17

4. Limites objetivos do efeito vinculante - a teoria da transcendência dos motivos determinantes $\quad 24$

4.1. Vantagens da aplicação da teoria 30

4.2. Vertente não democrática da teoria 34

4.3. Modo de aplicação da teoria 47

5. Dificuldades da aplicação da teoria no Direito Brasileiro $\mathbf{5 6}$

5.1. Contagem de votos não leva em conta os fundamentos da decisão $\quad \mathbf{6 0}$

5.2. Grande extensão dos votos dos Ministros do STF 63

6. Instrumento adequado para a implantação da teoria - a Reclamação $\begin{array}{lr}\text { Constitucional } & 65\end{array}$

$\begin{array}{ll}\text { 7. A jurisprudência do STF sobre o tema } & 78\end{array}$

8. Aplicação da teoria por outros Tribunais Superiores 91

$\begin{array}{lr}\text { Conclusão } & 95\end{array}$

$\begin{array}{lr}\text { Bibliografia } & 98\end{array}$ 


\section{Abreviações}

ADC - Ação Declaratória de Constitucionalidade

ADIn - Ação Direta de Inconstitucionalidade

ADIo - Ação Direta de Inconstitucionalidade por Omissão

ADPF - Arguição de Descumprimento de Preceito Fundamental.

CC - Código Civil

CF - Constituição da República Federativa do Brasil de 1988

CPC - Código de Processo Civil

CPP - Código de Processo Penal

EC - Emenda Constitucional

LC - Lei Complementar

Min. - Ministro (a)

Rcl - reclamação

STA - Suspensão da Tutela Antecipada

STJ - Superior Tribunal de Justiça

STF - Supremo Tribunal Federal

TJ - Tribunal de Justiça Estadual

TRE - Tribunal Regional Eleitoral

TRF - Tribunal Regional Federal

TRT - Tribunal Regional do Trabalho

TSE - Tribunal Superior Eleitoral

TST - Tribunal Superior do Trabalho 


\section{Introdução:}

A doutrina constitucionalista ${ }^{1}$ e o Supremo Tribunal Federal $^{2}$ têm travado debates em grande parte de seus pronunciamentos acerca da teoria que se convencionou chamar de teoria da transcendência dos motivos determinantes. Deve-se adiantar que seu acolhimento não é evidenciado em nenhum diploma normativo no ordenamento jurídico brasileiro. Trata-se de criação pretoriana.

O grande debate jurídico acerca do tema gira em torno dos limites objetivos conferidos ao efeito vinculante dos julgamentos do STF em sede de controle abstrato de constitucionalidade. Tradicionalmente, adota-se o entendimento de que só é vinculante a parte dispositiva do acórdão. De fato, o CPC, art. 469, I dispõe que os motivos determinantes do acórdão não fazem coisa julgada. Dessa forma, promovendo confusão entre os conceitos de coisa julgada, eficácia erga omnes e efeito vinculante das decisões do Supremo em controle concentrado de constitucionalidade, a doutrina tradicional $^{3}$ afirma que os motivos que determinaram o rumo da parte dispositiva não são levados em consideração na análise da extensão da decisão que será dotada de efeito vinculante.

Entretanto, vozes qualificadas na doutrina ${ }^{4}$ e nos Tribunais ${ }^{5}$ têm apontado outra direção. Partindo da distinção entre os conceitos de coisa julgada, eficácia erga omnes e efeito vinculante, esses autores afirmam que, não somente é possível, mas também desejável, que os motivos determinantes de certas decisões do STF sejam abrangidos pelo efeito

1 MENDES, Gilmar Ferreira; COELHO, Inocêncio Mártires; BRANCO, Paulo Gustavo Gonet. Curso de direito constitucional, $2^{\mathrm{a}}$ edição, revista e atualizada. São Paulo: Saraiva, 2008, p. 1291; MELLO, Patrícia Perrone Campos. Precedentes - $O$ desenvolvimento judicial do direito no constitucionalismo contemporâneo. Rio de Janeiro: Renovar, 2008, p. 148; FERNANDES, André Dias. Eficácia das decisões do STF em ADIN e ADC. Efeito vinculante, coisa julgada erga omnes e eficácia erga omnes. Salvador: Jus Podivm, 2009, p. 203.

2 STF, Rcl 1987-DF, Rel. Min. Maurício Corrêa, 01.10.2003.

3 FERRARI, Regina M. M. Nery. Efeitos da declaração de inconstitucionalidade. $4^{\mathrm{a}}$ edição. São Paulo: Revista dos Tribunais, 1999, p. 254.

4 MARTINS, Ives Gandra; MENDES, Gilmar Ferreira. Controle Concentrado de Constitucionalidade: comentários à Lei $n^{\circ}$ 9.868, de 10-11-1999. São Paulo: Saraiva, 2001, pp. 543-536; CLÈVE, Clèmerson Merlin. A fiscalização abstrata de constitucionalidade no direito brasileiro. $2^{a}$ edição. São Paulo: Revista dos Tribunais, 2000, pp. 307-311.

5 STF, Rcl 1987-DF, Rel. Min. Maurício Corrêa, 01.10.2003. 
vinculante.

Vale destacar, em resumo do tema, um breve trecho da obra de Luís Roberto Barroso sobre o tema:

"Em sucessivas decisões, o Supremo Tribunal Federal tem estendido os limites objetivos e subjetivos das decisões proferidas em sede de controle abstrato de constitucionalidade, com base em uma construção que vem denominando transcendência dos motivos determinantes. Por essa linha de entendimento, tem sido reconhecida eficácia vinculante não apenas à parte dispositiva do julgado, mas também aos próprios fundamentos que embasaram a decisão. Em outras palavras: juízes e tribunais devem acatamento não apenas à conclusão do acórdão, mas igualmente às razões de decidir. Como consequência, tem-se admitido reclamação contra qualquer ato, administrativo ou judicial, que contrarie a interpretação constitucional consagrada pelo Supremo Tribunal Federal em sede de controle concentrado de constitucionalidade, ainda que a ofensa se dê de forma oblíqua. E mais: a legitimidade ativa para a medida tem sido conferida a terceiros - isto é, a quem não foi parte no processo objetivo de controle concentrado -, desde que necessária para assegurar o efetivo respeito aos julgados da Corte". 6

Tal discussão não é meramente acadêmica, podendo gerar grandes alterações práticas no universo jurídico brasileiro. Afirmar que os fundamentos orientadores das principais decisões do STF devem ser levados em consideração pelos demais órgãos do Poder Judiciário e da Administração Pública pode causar uma imensa revolução na forma de se tratar as questões já discutidas pelo Supremo.

Como visto, a principal consequência seria o cabimento da Reclamação contra decisões de instâncias primárias que deixassem de observar os fundamentos das decisões proferidas pelo STF. O instituto da Reclamação $^{7}$ pode ser utilizado por qualquer interessado sempre que prejudicado por uma decisão judicial em confronto com precedente vinculante do STF.

6 BARROSO, Luís Roberto. O controle de constitucionalidade no direito brasileiro: exposição sistemática da doutrina e análise crítica da jurisprudência. $2^{\mathrm{a}}$ edição, revista e atualizada. São Paulo: Saraiva, 2007, p. 184-185.

7 A reclamação é um remédio constitucionalmente previsto, no art. 102, I, 1, verbis:

"Art. 102. Compete ao Supremo Tribunal Federal, precipuamente, a guarda da Constituição, cabendo-lhe:

I - processar e julgar, originariamente:

(...)

l) a reclamação para a preservação de sua competência e garantia da autoridade de suas decisões". 
A implementação da teoria seria natural num sistema judiciário hierarquizado como é o brasileiro ${ }^{8}$. Contudo, sua adoção poderia gerar um grande acúmulo de reclamações no STF, uma vez que os particulares teriam uma via de acesso direta ao STF, sem ter que passar pelos diversos "filtros" que são indispensáveis para os recursos extraordinários.

Seja como for, verifica-se que a jurisprudência ${ }^{9}$ tem vacilado quanto à adoção da teoria. Em princípio, a teoria chegou a ser acolhida e utilizada em alguns julgados. Porém, o STF recuou e, hoje, não mais se vale da teoria em seus julgados, chegando a declarar expressamente que ela foi rechaçada ${ }^{10}$.

Porém, a ordem jurídica no Brasil tem se desenvolvido rumando para ficar cada vez mais próxima à dos países da Commom Law. Alguns institutos estranhos à tradição dos países de Civil Law, como a repercussão geral, o julgamento de recursos repetitivos etc., revelam uma tendência de dar maior valor aos precedentes judiciais. Tal tendência se revela com maior força nas ações de controle de constitucionalidade, especialmente, nas ações de controle concentrado abstrato, como a ADC e a ADIn, cujas decisões são dotadas de efeito vinculante e eficácia erga omnes.

Portanto, não é de todo impossível a adoção da teoria nos moldes atuais do Direito brasileiro. Além disso, a aplicação da teoria se mostraria benéfica ao Direito brasileiro. Trata-se de importante instrumento processual que garante a aplicação de diversos princípios constitucionais, especialmente os princípios da segurança jurídica, da isonomia e da economia processual, como se verá ao longo deste trabalho.

8 Uma das características mais marcantes da hierarquia é o poder que o órgão "superior" tem de alterar decisões de órgãos "subalternos". Apesar de isso só ser possível após a devida provocação de quem tem interesse jurídico, por respeito ao princípio da inércia da jurisdição, verifica-se, no âmbito do Judiciário brasileiro, que as decisões das instâncias primárias são passíveis de modificação pelas instâncias secundárias, através dos recursos processuais. Dessa forma, constrói-se a hierarquia do Judiciário, ocupando o Supremo Tribunal Federal o topo dessa cadeia. Segue esse posicionamento Gisele Santos Fernandes Góes. A Reclamação Constitucional. In: NERY JR., Nelson, WAMBIER, Teresa Arruda Alvim (coordenadores). Aspectos polêmicos e atuais dos recursos cíveis e de outros meios de impugnação às decisões judiciais. São Paulo: Revista dos Tribunais, 2005, p. 141.

9 STF, Rcl 6204-AL AgRg, Rel. Min. Eros Grau, 06.05.10.

10 Rcl 2990-AgR, Rel. Min. Sepúlveda Pertence, DJ de 14.09.07. 
O presente estudo analisará diversos aspectos das decisões do STF em controle abstrato de constitucionalidade, principalmente no que se refere aos processos de ADIn e ADC. Há outros processos com características semelhantes (ADPF, ADIo, Ação Direta Interventiva), porém, por suas peculiaridades, o presente trabalho se utilizará a expressão controle concentrado abstrato de constitucionalidade em referência unicamente aos processos de de ADIn $\mathrm{e}$ ADC. 


\section{A importância dos precedentes judiciais no Brasil:}

A doutrina sempre tratou a jurisprudência como uma das fontes do direito $^{11}$, ao lado das leis, dos costumes etc. Miguel Reale ${ }^{12}$ define jurisprudência como "a forma de revelação do direito que se processa através do exercício da jurisdição, em virtude de uma sucessão harmônica de decisões”.

Apesar de o Direito brasileiro seguir a tradição romano-germânica, é possível ver a grande influência dos precedentes judiciais no Direito pátrio. De fato, ultimamente pode-se observar uma aproximação entre os sistemas jurídicos da Civil Law, caracterizado pelo apego à legislação, e da Common Law, caracterizado pela importância dos precedentes judiciais.

Desde o período colonial, com os $\operatorname{assentos}^{13}$, até a previsão da súmula vinculante, há poucos anos ${ }^{14}$, o Direito Brasileiro tem se inclinado à aceitação dos precedentes judiciais como parte do ordenamento jurídico, de forma que a importância da jurisprudência como fonte de Direito teve uma evolução contínua.

No tocante ao controle de constitucionalidade das leis e demais atos normativos, o Brasil adotou, desde a Constituição de 1891, o sistema difuso, sob a influência norte-americana. A Constituição de 1934 trouxe a possibilidade de o Senado Federal suspender a execução de leis declaradas inconstitucionais pelo STF. Somente a Emenda Constitucional $\mathrm{n}^{\mathrm{o}} 16$ de 1965 trouxe para o Direito Constitucional positivo do Brasil a previsão de controle abstrato de constitucionalidade, sob a influência do Direito alemão.

11 JUNIOR, Tércio Sampaio Ferraz, Introdução ao Estudo do Direito, $4^{a}$ edição. São Paulo: Atlas, 2003, página 241.

12 REALE, Miguel, Lições Preliminares de Direito, $27^{\text {a }}$ edição. São Paulo: Saraiva, 2002, página 167.

13 Assentos eram enunciados judiciais de caráter normativo que serviam como parâmetro na interpretação de normas. Foram criados pelas Ordenações Manuelinas e mantidos pelas Ordenações Filipinas. Eram produzidos pela Casa da Suplicação, tribunal superior de Portugal. Posteriormente, foi criado o Tribunal da Relação do Rio de Janeiro, que também poderia produzir assentos, que deveriam ser aprovados pela Casa de Suplicação. A partir da independência, este Tribunal foi transformado em Casa de Suplicação para o Brasil e passou a produzir os assentos livremente (TUCCI, José Rogério Cruz e. Precedente Judicial como Fonte do Direito. São Paulo: Revista dos Tribunais, 2004, pp. 131-147).

14 Emenda Constitucional $\mathrm{n}^{\circ} 45$ de 8 de dezembro de 2004, que inseriu o art. 103-A na Constituição Federal de 1988. 
Tal controle abstrato ocorria por meio da representação de inconstitucionalidade, cujo único legitimado ativo era o Procurador-Geral da República.

Essas alterações mostraram-se pertinentes pela necessidade de atribuição de força normativa a algumas decisões da Corte Suprema. A doutrina $^{15}$ ressalta que a introdução do modelo abstrato de controle se deu por uma necessidade de diminuição do número de processos que chegavam ao Supremo Tribunal Federal, muitos deles versando sobre temas que já tinha sido objeto de apreciação.

Todavia, a adoção do modelo estadunidense de judicial reveiw pela ordem constitucional brasileira demonstrou-se incompleta. Nos Estados Unidos, a Suprema Corte só analisa a constitucionalidade de leis no bojo de um caso concreto, porém, sua decisão é dotada de efeito vinculante e eficácia erga omnes, o que não acontece no Brasil, em sede de controle difuso de constitucionalidade.

A Constituição Federal de 1988 manteve o sistema misto de controle de constitucionalidade, adotando o modelo concentrado abstrato e o modelo incidental concreto ${ }^{16}$.

Tanto pelo momento em que foi promulgada, quanto pelo seu conteúdo, percebe-se que a Constituição de 1988 representou um grande avanço na construção da força dos precedentes no Direito brasileiro.

Primeiramente, devido ao momento histórico que vivia o País

15 VIEIRA, Oscar Vilhena. Supremo Tribunal Federal: Jurisprudência Política, $2^{\mathrm{a}}$ edição. São Paulo: Malheiros, 2002, pp.122-123.

16 Controle de constitucionalidade difuso não é sinônimo de controle incidental, da mesma forma que controle concentrado não é sinônimo de controle abstrato. Os critérios para essas classificações são distintos. Quando diferenciamos o controle difuso e o controle concentrado utilizamos o critério da competência para a declaração de inconstitucionalidade, verificando qual órgão é competente para declarar uma lei inconstitucional. Quando diferenciamos o controle incidental do controle abstrato utilizamos o critério da forma do exercício do controle de constitucionalidade. O controle é concentrado se só é realizado por um órgão judicial político. O controle é difuso se mais de um órgão ou todos os órgãos judiciários têm a prerrogativa de declarar atos normativos inconstitucionais. Da mesma forma, o controle é abstrato se a análise da constitucionalidade da lei constitui a principal questão do processo judicial. O controle é incidental se a análise da constitucionalidade da lei constitui um incidente processual cuja análise é uma questão prejudicial, um antecedente lógico e necessário para decisão de mérito. Portanto, essa combinação de controle incidental-difuso e abstratoconcentrado não é necessária, apesar de ser uma combinação existente no Direito Brasileiro. 
quando da sua promulgação, em outubro de 1988, a Carta Magna representou politicamente um marco na redemocratização do Brasil, que, após mais de duas décadas sob um regime ditatorial militar, pôde ler em seu principal texto normativo que todo o poder emana do povo ${ }^{17}$. A redemocratização significou um retorno da independência e da autonomia do Poder Judiciário e sua harmonia ao com os demais Poderes da República, o Executivo e o Legislativo. Isso tornou o universo jurídico brasileiro um ambiente propício para o desenvolvimento do Direito através dos precedentes judiciais.

Também se deve atentar para o fato de que o conteúdo da Carta de 1988 reforça o argumento do grande relevo que se concedeu à jurisprudência. $\mathrm{O}$ extenso rol de direitos fundamentais e o grande número de princípios espalhados por todo o texto, numa época de ascensão do neoconstitucionalismo, foi o combustível necessário para se atribuir força normativa aos princípios, para se admitir a resolução de conflitos por meio da ponderação, com o auxílio dos postulados normativos da razoabilidade e da proporcionalidade, e para reconhecer a eficácia irradiante das normas constitucionais $^{18}$.

Além disso, a Constituição de 1988, ao tratar do controle de constitucionalidade das leis e atos normativos, previu um amplo rol de legitimados para a propositura de ações de controle abstrato e atribuiu efeito vinculante a certas decisões do STF, isso sem retirar a possibilidade de qualquer pessoa questionar a constitucionalidade de leis num determinado caso concreto (controle difuso de constitucionalidade). Esses são sinais claros do que se convencionou chamar de constitucionalização do Direito ${ }^{19}$, fenômeno marcado pela ascensão da Constituição ao topo do ordenamento

17 “Art. 10: A República Federativa do Brasil (...) constitui-se em Estado Democrático de Direito (...); Parágrafo único. Todo o poder emana do povo, que o exerce por meio de representantes eleitos ou diretamente, nos termos desta Constituição".

18 MELLO, Patrícia Perrone Campos. Precedentes - O desenvolvimento judicial do direito no constitucionalismo contemporâneo. Rio de Janeiro: Renovar, 2008, p.57.

19 OLIVEIRA, Rafael Carvalho Rezende. A constitucionalização do Direito Administrativo. O princípio da juridicidade, a releitura da legalidade administrativa e a legitimidade das agências reguladoras. Rio de Janeiro: Lumen Juris, 2010, p. 26. 
jurídico e pelo reconhecimento da normatividade de seus dispositivos.

\author{
Com efeito, há alguns sinais evidentes da elevada posição que \\ ocupam os precedentes judiciais como fontes do Direito no ambiente \\ jurídico brasileiro atual. Patrícia Perrone Campos de Mello cita alguns \\ deles:
}

“a) a criação da ação declaratória de constitucionalidade (Emenda Constitucional $n^{\circ} 3 / 1993$ ); b) a extensão dos efeitos vinculantes e gerais aos casos de interpretação conforme a Constituição e de declaração parcial de inconstitucionalidade sem redução de texto (art. 28, parágrafo único, da Lei $\mathrm{n}^{\circ}$ 9.868/1999); c) a regulação da Arguição de Descumprimento de Preceito Fundamental (Lei ${ }^{\circ}$ 9.882/1999); d) a introdução da súmula vinculante (Emenda Constitucional no 45/2004); e) a atribuição de poderes ao relator para inadmitir recursos em confronto com súmula (simples) ou jurisprudência dominante, e para dar provimento àqueles em harmonia com entendimentos prevalecentes no STF ou em tribunais superiores (art. 557, caput e $\S 1^{\circ}, \mathrm{CPC}$, com redação conferida pela Lei $\left.\mathrm{n}^{\circ} 9.756 / 1998\right)$; f) a dispensa da obrigação de submissão da arguição incidental de inconstitucionalidade ao plenário quando já houver pronunciamento do Supremo Tribunal Federal ou do próprio tribunal a respeito (art. 481, parágrafo único, CPC, incluído pela Lei $\mathrm{n}^{\circ}$ 9.756/1998); g) a determinação de que as decisões proferidas contra a Fazenda Pública produzirão efeitos, independentemente de submissão ao duplo grau de jurisdição, quando estiverem em consonância com a jurisprudência do plenário do STF ou com súmula deste ou do tribunal superior competente (art. 475, § $3^{\circ}, \mathrm{CPC}$ ); h) a possibilidade de desconstituição de coisa julgada, caso o título judicial se funde em lei ou ato normativo declarado inconstitucional pela Corte Constitucional, ou se baseie em aplicação ou interpretação tida por ela como incompatível com a Constituição Federal (art. 475-L, inc. II e $\S 1^{\circ}$, CPC, e art. 741, parágrafo único); i) a presunção de que o requisito de "repercussão geral", necessário ao conhecimento de recurso extraordinário, estará presente quando $\mathrm{o}$ acórdão contrariar súmula ou jurisprudência dominante do STF (art. 543-A, § $3^{\circ}$, introduzido pela Lei 11.418/2006); j) a previsão de que, em questões que ensejam multiplicidade de recursos extraordinários idênticos, a orientação firmada pela Corte Constitucional sobre a matéria, em um caso paradigma, abrirá para o tribunal de origem a possibilidade de declarar prejudicados apelos idênticos nele sobrestados ou de se retratar de suas decisões anteriores, objeto de outros recursos extraordinários que ali se encontrem, sob pena de, não o fazendo, tê-las liminarmente cassadas ou reformadas no STF (art. 543-B, $\S 3^{\circ}$, introduzido pela Lei $\left.\mathrm{n}^{\mathrm{o}} 11.418 / 2006\right) .{ }^{, 20}$

Outro fato que evidencia a normatividade dos precedentes cada vez mais acentuada é a intensa atividade jurídica pretoriana com a edição de súmulas. As súmulas correspondem a entendimentos já consolidados pelos Tribunais e que são constantemente adotados em casos que versem sobre a 
mesma questão. Cada súmula retrata uma "norma" que foi utilizada pelo Tribunal para o julgamento de alguns casos semelhantes. A súmula simples não tem caráter normativo, mas pode ser utilizada por juízos de graus inferiores para a resolução de casos.

O Direito Processualista Civil, entretanto, tem conferido certo caráter normativo às súmulas do STF e do STJ. Por exemplo, o art. 518, § $1^{\text {o21 }}$ prevê que o juiz não deve receber a apelação interposta contra decisão que esteja em conformidade com súmula do STF ou do STJ. O art. 543-A, § $3^{\mathrm{o} 22}$, também do $\mathrm{CPC}$, presume a repercussão geral quando o recurso extraordinário é usado para atacar decisão que contraria súmula do STF. Outro exemplo, constante do CPC, art. $544, \S 4^{\circ}, \mathrm{II}, \mathrm{b}^{23}$, é a previsão de que o relator pode negar seguimento ao recurso extraordinário ou recurso especial que está em confronto com súmula do STF ou STJ, quando do julgamento do agravo contra decisão que não admite tais recursos.

Mais recentemente a EC 45/2004 incluiu no texto da Constituição Federal o art. 103-A, que trouxe a previsão das súmulas vinculantes e foi regulamentado pela Lei 11.417/2006. As súmulas vinculantes têm um procedimento especial e requisitos específicos para a aprovação pelo STF. Quando uma súmula vinculante é aprovada, como seu próprio nome sugere, seu enunciado se torna de obrigatória observância aos demais órgãos do Poder Judiciário e à Administração Pública Direta e Indireta, nas esferas federal, estadual e municipal.

Tendo em vista essa tendência do Direito Brasileiro de valorização

$21 \mathrm{CPC}$, art. 518, $\S 1^{\circ}$ : “O juiz não receberá o recurso de apelação quando a sentença estiver em conformidade com súmula do Superior Tribunal de Justiça ou do Supremo Tribunal Federal. (Renumerado pela Lei $\mathrm{n}^{\circ}$ 11.276, de 2006)".

$22 \mathrm{CPC}$, art. 543-A, § 30: "Haverá repercussão geral sempre que o recurso impugnar decisão contrária a súmula ou jurisprudência dominante do Tribunal. (Incluído pela Lei ${ }^{\circ} 11.418$, de 2006)"'.

23 CPC, art. 544, $\S 4^{\circ}$ : No Supremo Tribunal Federal e no Superior Tribunal de Justiça, o julgamento do agravo obedecerá ao disposto no respectivo regimento interno, podendo o relator:

$(\ldots)$

II - conhecer do agravo para:

(...)

b) negar seguimento ao recurso manifestamente inadmissível, prejudicado ou em confronto com súmula ou jurisprudência dominante no tribunal; (incluído pela Lei $\mathrm{n}^{\mathrm{o}} 12.322$, de 2010)". 
dos precedentes judiciais, é possível prever que, nos próximos anos, o País sofrerá outras mudanças que adequem ainda mais a forma de lidar com o Direito à normatividade da jurisprudência. Obviamente, isso representa um longo processo de transformação, não um ato único, mas é preciso se abrir para receber novos conceitos e rever fundamentos enraizados, especialmente no que diz respeito à eficácia dos precedentes.

Por fim, deve-se destacar que é normal que os precedentes ganhem força normativa, ainda mais em sistemas jurídicos complexos como o brasileiro. O atual conceito de interpretação constitucional, como se verá adiante, vem ao encontro deste entendimento, de modo a facilitar a aceitação da normatividade dos precedentes. 


\section{Efeito vinculante, eficácia erga omnes e coisa julgada erga omnes:}

Como se sabe, a Constituição Federal concedeu eficácia contra todos (ou eficácia erga omnes) e efeito vinculante às decisões do STF proferidas em Ação Declaratória de Constitucionalidade ${ }^{24}$, por meio da Emenda Constitucional n 3 de 1993.

O $\operatorname{STF}^{25}$ sempre entendeu que esse efeito vinculante não pode ser restrito à $\mathrm{ADC}$, devendo também ser concedido aos demais instrumentos de controle abstrato de constitucionalidade, como a ADIn.

Posteriormente, a lei regulamentadora desta ação constitucional positivou expressamente este entendimento. É o que se percebe na Lei. 9.868/99, art. 28, parágrafo único ${ }^{26}$.

É possível notar certa atecnia da doutrina ${ }^{27}$ ao tratar dos conceitos de efeito vinculante, de eficácia erga omnes e de coisa julgada erga omnes, pois muitas vezes tais expressões aparecem uma ao lado da outra para aludir à mesma situação jurídica, como conceitos afins, sem que seja feita qualquer diferenciação.

Entretanto, alguns autores, como é o caso de Gilmar Ferreira Mendes ${ }^{28}$, têm procurado distinguir esses conceitos. Essa parte da doutrina é pacífica ao dizer que a decisão dotada de eficácia erga omnes é aquela que deve ser observada por todos os particulares, já que os limites subjetivos da decisão extrapolam as eventuais partes no processo. Já a decisão dotada de efeito vinculante seria aquela que deveria ser necessariamente observada pelos demais órgãos do Poder Judiciário e da Administração Pública no

$24 \mathrm{CF}$, art. $102, \S 2^{\circ}$.

25 STF, ADC 01, rel. Min. Moreira Alves, 01.12.1993.

26 "A declaração de constitucionalidade ou de inconstitucionalidade, inclusive a interpretação conforme a Constituição e a declaração parcial de inconstitucionalidade sem redução de texto, têm eficácia contra todos e efeito vinculante em relação aos órgãos do Poder Judiciário e à Administração Pública federal, estadual e municipal."

27 JÚNIOR, Humberto Teodoro. Curso de Direito Processual Civil, vol. 1 - Teoria gera do direito processual civil e processo de conhecimento. $50^{\mathrm{a}}$ ed. Rio de Janeiro: Forense, 2009, pp. 548550.

28 MENDES, Gilmar Ferreira. O efeito vinculante das decisões do Supremo Tribunal Federal nos processos de controle abstrato de normas. Revista Jurídica Virtual.Brasília, vol. 1, n. 4, agosto 1999. 
exercício de sua função pública.

A legislação parece ter enveredado por esse caminho, como se nota na Lei 9.868/99, art. 28, parágrafo único e na Constituição Federal, art. 102, $\S 2^{\text {o29 }}$.

Entretanto, é possível estabelecer outras distinções entre tais institutos. Comecemos por analisar a eficácia erga omnes das decisões do STF em controle abstrato de constitucionalidade. Toda decisão judicial, de qualquer órgão do Poder Judiciário, como um ato de império do Poder Público no exercício da jurisdição, pode ser oposta a todos. É da natureza de qualquer sentença (lato sensu) a oponibilidade erga omnes.

Então, por que dizer que os acórdãos do STF em controle abstrato de constitucionalidade são dotados de eficácia erga omnes, se todas as decisões que emanam do Poder Judiciário também são oponíveis erga omnes? Na verdade, o fato de toda decisão do Poder Judiciário ser oponível a todos se baseia em um conceito diferente do conceito de eficácia erga omnes daquelas decisões específicas do STF.

Todos os atos judiciais têm uma eficácia natural ${ }^{30}$ que atinge a todos da sociedade, inclusive terceiros que não fizeram parte do processo. Como ressalta Liebman, "a eficácia da sentença, nos limites de seu objeto, não sofre nenhuma limitação subjetiva; vale em face de todos (...) todos os terceiros estão sujeitos à eficácia da sentença”,31. Entretanto, tal eficácia natural tem uma limitação expressa, que advém do princípio do devido processo legal: ela não pode prejudicar terceiros.

Tal limitação é verificada com frequência nas disposições do CPC que, por exemplo, confere ao terceiro juridicamente interessado legitimidade para propositura de ação rescisória (art. 487, II), confere ao

29 “As decisões definitivas de mérito, proferidas pelo Supremo Tribunal Federal, nas ações diretas de inconstitucionalidade e nas ações declaratórias de constitucionalidade produzirão eficácia contra todos e efeito vinculante, relativamente aos demais órgãos do Poder Judiciário e à administração pública direta e indireta, nas esferas federal, estadual e municipal. (Redação dada pela Emenda Constitucional no 45, de 2004)"

30 FERNANDES, André Dias. Eficácia das decisões do STF em ADIN e ADC. Efeito vinculante, coisa julgada erga omnes e eficácia erga omnes. Salvador: Jus Podivm, 2009, p. 163.

31 LIEBMAN, Enrico Tulio. Eficácia e autoridade da sentença. $3^{\mathrm{a}}$ edição brasileira. Trad.: Ada Pellegrini Grinover, Alfredo Buzaid e Benvindo Aires. Rio de Janeiro: Forense, 1984, p.170. 
terceiro prejudicado legitimidade para interposição de recursos (art. 499, § $1^{\circ}$ ), além de conferir a terceiros a possibilidade de intervir no processo (arts. 56 a 80$)$.

Contudo, as decisões do STF em processos objetivos (controle concentrado abstrato de constitucionalidade) são dotadas de eficácia erga omnes. Isso significa dizer que nem mesmo terceiros interessados ou prejudicados pelo acórdão do Supremo podem rediscuti-lo em juízo. Assim, dizer que tais decisões do STF têm eficácia erga omnes significa dizer que elas têm uma eficácia além da natural de toda decisão judicial. André Fernandes sintetiza a questão:

"A diferença entre a eficácia erga omnes e a eficácia natural da sentença $e$ dos demais atos judiciais proferidos nos processos subjetivos consiste unicamente na possibilidade de afastamento dessa eficácia pela alegação de prejuízo jurídico por terceiros, que não existe nos processos objetivos, 32 .

Insta, ainda, ressaltar que a eficácia erga omnes é inerente aos processos objetivos, aqueles em que não há interesse subjetivo e em que a questão jurídica é diretamente analisada pelo magistrado. A eficácia erga omnes dos acórdãos do STF proferidos em controle abstrato de constitucionalidade corresponde à eficácia natural das decisões judiciais, só que proferidas em processo objetivo. De tal forma que arremata o jurista supracitado:

"Justamente pela possibilidade de afastamento da eficácia natural da sentença e dos demais atos judiciais proferidos nos processos subjetivos mediante a alegação de prejuízo jurídico por terceiros é que distinguimos entre a eficácia "aparentemente erga omnes" (das sentenças e demais atos judiciais nos processos subjetivos) e a eficácia "realmente erga omnes" (dos acórdãos e demais atos judiciais proferidos nos processos objetivos), incompossível com esse afastamento" ${ }^{33}$.

Este conceito é de longe diferenciado do conceito de coisa julgada erga omnes, que é uma qualidade exclusiva dos acórdãos definitivos de mérito do STF nos processos objetivos. Tal qualidade confere a estas decisões, primordialmente, as características da imutabilidade e da 
indiscutibilidade.

Uma diferença básica que se pode apontar é que a eficácia erga omnes abrange as sentenças, os despachos de mero expediente e as decisões interlocutórias (incluindo tanto as que deferem quanto as que indeferem medida cautelar). Entretanto, a coisa julgada erga omnes abrange tãosomente as decisões que sejam acórdãos definitivos de mérito em processos objetivos de controle abstrato de constitucionalidade (ADIn e ADC), não alcançando as decisões interlocutórias e os despachos.

Além disso, a coisa julgada é, essencialmente, um instituto que surge quando da preclusão de todos os recursos, no momento em que a sentença transita em julgado tornando-se imutável e indiscutível ${ }^{34}$. A doutrina processualista $^{35}$ costuma dividir a coisa julgada em formal (imutabilidade $\mathrm{e}$ indiscutibilidade da sentença no mesmo processo) e coisa julgada material (imutabilidade e indiscutibilidade da sentença em qualquer processo).

Normalmente, a impossibilidade de rediscutir e de modificar o que é objeto de coisa julgada atinge somente as partes que tiveram participação no processo, como proteção ao princípio do devido processo legal.

Todavia, quando falamos de coisa julgada erga omnes, estamos examinando uma coisa julgada (no sentido de qualidade da sentença) que extrapola os limites subjetivos da lide, tornando-a imutável e indiscutível também para terceiros que não participaram da relação processual.

A doutrina também aborda as chamadas modalidades de eficácia da coisa julgada. Luís Roberto Barroso traz importante lição neste sentido:

"A primeira é denominada de eficácia preclusiva: a matéria coberta pela
autoridade da coisa julgada não poderá ser objeto de novo
pronunciamento judicial. Já a segunda modalidade, a eficácia vinculativa,
significa que a autoridade da coisa julgada deverá prevalecer na solução
de qualquer lide que esteja logicamente subordinada à questão já
resolvida"36.

34 GRECO, Leonardo. Instituições de Processo Civil, volume 1. Rio de Janeiro: Forense, 2010, p. 209.

35 JÚNIOR, Humberto Teodoro. Curso de Direito Processual Civil - Teoria gera do direito processual civil e processo de conhecimento. Rio de Janeiro: Forense, 2009, p. 526.

36 BARROSO, Luís Roberto. $O$ controle de constitucionalidade no direito brasileiro: exposição sistemática da doutrina e análise crítica da jurisprudência. $2^{\mathrm{a}}$ edição, revista e atualizada. São Paulo: Saraiva, 2007. p.173, 174. 
O último conceito a ser abordado é o de efeito vinculante, que pode ser definido como o efeito que, caso presente em determinada decisão, faz com que esta se torne de observância obrigatória a outros órgãos judiciais e administrativos, permitindo que o órgão prolator da decisão reforme ou anule qualquer outra decisão em sentido contrário, de forma a impedir que a decisão vinculante tenha sua autoridade violada.

O legislador (constitucional e infraconstitucional) também dotou os acórdãos do Supremo em controle abstrato de constitucionalidade de efeito vinculante. Pela redação dos dispositivos legais anteriormente destacados (art. 28, parágrafo único da Lei 9.868/1999 e art. 102, § $2^{\circ}$ da CRFB/88), vemos que o efeito vinculante se difere tanto da eficácia erga omnes quanto da coisa julgada erga omnes.

Primeiramente, deve-se destacar o fato de que efeito vinculante e coisa julgada erga omnes são institutos díspares e independentes. Tanto é assim que é possível haver uma decisão com efeito vinculante que não produza coisa julgada erga omnes (como a decisão que defere medida cautelar em processos de controle abstrato de constitucionalidade), da mesma forma que é possível haver decisão sem efeito vinculante, mas dotada de coisa julgada erga omnes. Como exemplo deste último caso, podemos citar qualquer decisão proferida em controle abstrato de constitucionalidade antes do advento da EC 3/93, que trouxe o efeito vinculante para o ordenamento jurídico brasileiro.

Desse detalhe é possível extrair uma diferença marcante entre efeito vinculante e coisa julgada erga omnes: enquanto a segunda é uma decorrência natural do caráter objetivo do processo, o primeiro é uma opção legislativa, podendo ou não existir, ainda que em processos objetivos.

Outra diferença incisiva é quanto à finalidade dos institutos, uma vez que o efeito vinculante serve para tornar obrigatória aos demais órgãos do Poder Judiciário e à Administração Pública a aplicação dos precedentes do STF sempre que diante de hipóteses semelhantes. Por sua vez, a coisa 
julgada erga omnes tem por fim impedir que se rediscuta ou modifique a mesma exata questão já analisada no julgado do Supremo.

Além disso, nota-se que a coisa julgada erga omnes alcança o próprio STF, enquanto que o efeito vinculante exclui de seu âmbito de aplicação o STF. Isso porque o Supremo sempre poderá decidir de maneira diferente diante de casos semelhantes, porém, não poderia voltar atrás em uma de suas decisões após o trânsito em julgado do acórdão.

Por fim, também existe uma diferença em relação à técnica processual para o cumprimento destes institutos. No caso da coisa julgada, sendo esta alegada ou reconhecida de ofício, o juiz deve extinguir o processo sem resolução de mérito, na forma do CPC, art. 267, V. No caso de efeito vinculante, o juiz deve decidir a questão em conformidade com o que decidiu o STF, não podendo se esquivar do dever de julgar. Nas palavras de Barbosa Moreira:

"Haverá ofensa à coisa julgada quer na hipótese de o novo pronunciamento ser conforme ao primeiro, quer na de ser desconforme: $\mathrm{o}$ vínculo não significa que o juiz esteja obrigado a rejulgar a matéria em igual sentido, mas sim que ele está impedido de rejulgá-la. (...) Essa impossibilidade (de emitir novo pronunciamento sobre a matéria já decidida) às vezes só prevalece no mesmo processo em que se proferiu a decisão (coisa julgada formal), e noutros casos em qualquer processo (coisa julgada material)". ${ }^{37}$

Vale trazer à baila os conceitos doutrinários elaborados por André Dias Fernandes:

"O efeito vinculante consiste na obrigação dos órgãos do Poder Judiciário, à exceção do STF, e da Administração Pública direta e indireta (federal, estadual e municipal) de decidir, em situações análogas, em conformidade com a decisão do STF na ADIn ou na ADC. Já a coisa julgada erga omnes consiste na imutabilidade e indiscutibilidade, por quem quer que seja, da decisão final de mérito do STF em ADIn ou ADC, impedindo que se decida de novo a mesma questão constitucional que já foi decidida pelo STF"38. (grifos nossos).

A partir desse conceito de efeito vinculante (obrigação de decidir em conformidade com o precedente do STF), percebemos que este efeito está

37 MOREIRA, José Carlos Barbosa. Comentários ao Código de Processo Civil, v. 5. 11 a edição. Rio de Janeiro: Forense, 2003, p. 128.

38 FERNANDES, André Dias. Op. cit., p. 171. 
intrinsecamente relacionado à existência da Reclamação. Isso porque, se esta obrigação de observar o precedente não for cumprida, há um instrumento que garante a reforma de qualquer decisão em desconformidade com prévia decisão vinculante. Na verdade, bastaria a existência de um instituto semelhante à Reclamação que levasse à questão ao Tribunal que proferiu a decisão vinculante, de forma a garantir plena efetividade ao efeito vinculante.

Posteriormente, serão analisadas as peculiaridades que fazem com que a Reclamação seja um instrumento eficiente para a implementação do efeito vinculante.

Elucidadas as principais diferenças entre efeito vinculante, eficácia erga omnes e coisa julgada erga omnes, ruma-se agora para o cerne da questão referente à teoria da transcendência dos motivos determinantes, que consiste em saber qual é o alcance do efeito vinculante, mais precisamente, se a fundamentação da decisão é ou não coberta pelo efeito vinculante. 


\title{
4. Limites objetivos do efeito vinculante - a teoria da transcendência dos motivos determinantes:
}

A grande discussão trazida pela teoria da transcendência dos motivos determinantes refere-se à extensão do efeito vinculante conferido a algumas decisões do STF. Ou seja, busca-se resposta à pergunta: qual parte da decisão deve ser observada pelos demais órgãos do Poder Judiciário e da Administração Pública, por ser dotada de efeito vinculante?

A teoria da transcendência dos motivos determinantes se baseia tanto no conceito de efeito vinculante quanto no conceito de eficácia erga omnes, sustentando que eles não se restringem ao dispositivo, mas alcançam também os fundamentos da decisão. Nos dizeres de Patrícia Perrone:

\begin{abstract}
“A questão que se coloca quanto ao ponto é, portanto, se seria possível extrair do precedente produzido em âmbito concentrado um comando mais geral, que pudesse se referir não apenas à norma infraconstitucional objeto de discussão, mas igualmente a outras normas $e$ atos dentro de uma mesma categoria de similitude. (...) Por "eficácia transcendente da fundamentação" designa-se a possibilidade de extensão dos efeitos vinculantes e erga omnes aos "motivos determinantes da decisão", em lugar de sua restrição ao dispositivo do julgado." ${ }^{39}$
\end{abstract}

A questão, porém, dá relevo à função do efeito vinculante, que seria o ponto central da força dos precedentes.

No capítulo anterior ficou estabelecida a distinção entre eficácia erga omnes, coisa julgada erga omnes e efeito vinculante, deixando claro que o efeito vinculante é o efeito que, se presente por previsão legislativa, torna a decisão de observância obrigatória pelos demais órgãos do Poder Judiciário e da Administração Pública. Foi dito também que o efeito vinculante só foi conferido às decisões do STF em controle abstrato de constitucionalidade, por uma interpretação dos dispositivos que tratam do tema $(\mathrm{CF}$, art. 102, § $2^{\circ}$ e Lei. 9.868/99, art. 28, parágrafo único).

$\mathrm{O}$ efeito vinculante foi concebido com a clara finalidade de conferir maior abrangência ao trabalho realizado pelo Supremo Tribunal Federal, como órgão ocupante da cúpula do Poder Judiciário brasileiro. O STF é um

39 MELlO, Patrícia Perrone Campos. Precedentes - O desenvolvimento judicial do direito no constitucionalismo contemporâneo. Rio de Janeiro: Renovar, 2008, pp. 146, 148-149. 
Tribunal que julga mais de 120.000 causas $^{40}$ por ano, porém conta com apenas 11 Ministros. Como muitas dessas causas versam sobre a mesma questão jurídica $^{41}$, não seria inteligente levar à apreciação do STF cada uma delas para que sempre se decida a mesma controvérsia.

Por isso, a criação do efeito vinculante veio facilitar o julgamento de casos em massa, fazendo com que o STF se manifeste apenas uma vez sobre determinada questão.

Nesse ínterim, surge a discussão de qual seria a abrangência deste efeito vinculante, quais seriam os seus limites objetivos. Tradicionalmente, afirma-se que apenas a parte dispositiva das decisões, mais precisamente, dos acórdãos de mérito do STF em sede de controle abstrato de constitucionalidade, seria dotada do efeito vinculante.

Porém, modernamente, a doutrina ${ }^{42}$ e a jurisprudência ${ }^{43}$ têm questionado esta tradição do Direito Constitucional brasileiro. Como visto, hoje acontece uma grande aproximação do Direito brasileiro com a tradição do Common Law, de forma a deixar os institutos do Direito pátrio mais semelhantes ao Direito de países como os Estados Unidos da América, principalmente no que diz respeito ao controle de constitucionalidade. Isso tudo revela a tendência de incremento na atribuição de efeito vinculante às decisões do STF. Uma prova disso é o efeito vinculante introduzido no ordenamento pátrio pela Emenda Constitucional no 3 de 1993.

Gilmar Ferreira Mendes e Ives Gandra da Silva Martins trazem uma importante visão acerca do efeito vinculante e de seus limites objetivos ao analisar as inovações trazidas pela EC no 3/93 segundo o direito alemão, no qual buscou inspiração.

"A concepção de efeito vinculante consagrada pela Emenda n. 3, de 1993, está estritamente vinculada ao modelo germânico disciplinado no § 31 ,

40 Entrevista concedida pelo atual Presidente do STF o Ministro Cezar Peluso à Revista Veja, editora Abril, edição 2.172, ano 43, nº 27 07.07.10, p. 20.

41 Apesar de toda a riqueza do Direito Brasileiro, especialmente do Direito Constitucional, seria praticamente impossível o surgimento anual de centenas de milhares de questões jurídicas diferentes e tão complexas que necessitassem da apreciação individual e específica do Supremo Tribunal Federal.

42 MELlO, Patrícia Perrone Campos. Op. cit., p. 148.

43 STF, Rcl 2291-RJ/MC, Rel. Min. Gilmar Mendes, 27.03.2003. 
(2), da Lei orgânica da Corte Constitucional. A própria justificativa da proposta apresentada pelo Deputado Roberto Campos não deixa dúvida de que se pretendia outorgar não só eficácia erga omnes mas também efeito vinculante à decisão, deixando claro que estes não estariam limitados apenas à parte dispositiva. Embora a Emenda n. 3/93 não tenha incorporado a proposta na sua inteireza, é certo que o efeito vinculante, na parte que foi positivada, deve ser estudado à luz dos elementos contidos na proposta original.

Assim, parece legítimo que se recorra à literatura alemã para explicitar o significado efetivo do instituto.

A primeira indagação, na espécie, refere-se às decisões que seriam aptas a produzir o efeito vinculante. Afirma-se que, fundamentalmente, são vinculantes as decisões capazes de transitar em julgado. Tal como a coisa julgada, o efeito vinculante refere-se ao momento da decisão. Alterações posteriores não são alcançadas.

Problema de inegável relevo diz respeito aos limites objetivos do efeito vinculante, isto é, à parte da decisão que tem efeito vinculante para os órgãos constitucionais, tribunais e autoridades administrativas. Em suma, indaga-se, tal como em relação à coisa julgada e à força de lei, se o efeito vinculante está adstrito à parte dispositiva da decisão ou se ele se estende também aos chamados fundamentos determinantes, ou, ainda, se o efeito vinculante abrange também as considerações marginais, as coisas ditas de passagem, isto é, os chamados obiter dicta.

Enquanto em relação à coisa julgada e à força de lei domina a ideia de que elas hão de se limitar à parte dispositiva da decisão, sustenta o Tribunal Constitucional alemão que o efeito vinculante se estende, igualmente, aos fundamentos determinantes da decisão.

Segundo esse entendimento, a eficácia da decisão do Tribunal transcende o caso singular, de modo que os princípios dimanados da parte dispositiva e dos fundamentos determinantes sobre a interpretação da Constituição devem ser observados por todos os tribunais e autoridades nos casos futuros.

Outras correntes doutrinárias sustentam que, tal como a coisa julgada, o efeito vinculante limita-se à parte dispositiva da decisão, de modo que, do prisma objetivo, não haveria distinção entre a coisa julgada e o efeito vinculante.

A diferença entre as duas posições extremadas não é meramente semântica ou teórica, apresentando profundas consequências também no plano prático (subjacente à discussão sobre a amplitude do efeito vinculante reside uma questão mais profunda, relativa à própria ideia de jurisdição constitucional).

Enquanto o entendimento esposado pelo Tribunal Constitucional alemão importa não só na proibição de que se contrarie a decisão proferida no caso concreto em toda a sua dimensão, mas também na obrigação de todos os órgãos constitucionais de adequar a sua conduta, nas situações futuras, à orientação dimanada da decisão, considera a concepção que defende uma interpretação restritiva do $\S 31$, I, da Lei Orgânica do Tribunal Constitucional que o efeito vinculante há de ficar limitado à parte dispositiva da decisão, realçando, assim, a qualidade judicial da decisão.

A aproximação dessas duas posições extremadas é feita mediante o desenvolvimento de orientações mediadoras, que acabam por fundir elementos das concepções principais.

Assim, propõe Vogel que a coisa julgada ultrapasse os estritos limites da parte dispositiva, abrangendo também a "norma decisória 
concreta". A norma decisória concreta seria aquela "ideia jurídica subjacente à formulação contida na parte dispositiva, que, concebida de forma geral, permite não só a decisão do caso concreto, mas também a decisão de casos semelhantes". Por seu lado, sustenta Kriele que a força dos precedentes, que presumivelmente vincula os Tribunais, é reforçada no direito alemão pelo disposto no $\S 31$, I, da Lei do Tribunal Constitucional alemão. A semelhante resultado chegam as reflexões de Bachof, segundo o qual o papel fundamental do Tribunal Constitucional alemão consiste na extensão de suas decisões aos casos ou situações paralelas.

Tal como já anotado, parecia inequívoco o propósito do legislador alemão, ao formular o § 31 da Lei Orgânica do Tribunal, de dotar a decisão de uma eficácia transcendente.

É certo, por outro lado, que a limitação do efeito vinculante à parte dispositiva da decisão tornaria de todo despiciendo esse instituto, uma vez que ele pouco acrescentaria aos institutos da coisa julgada e da força de lei. Ademais tal redução diminuiria significativamente a contribuição do Tribunal para a preservação e desenvolvimento da ordem constitucional."44 (grifos nossos)

Portanto, é possível observar a aceitação, por parte da doutrina, quanto à teoria de que os limites objetivos do efeito vinculante extrapolam o dispositivo do julgado e alcançam também seus fundamentos.

A teoria da transcendência dos motivos determinantes busca alcançar apenas o controle concentrado abstrato de constitucionalidade. Este é o controle exercido por apenas um órgão, o STF, que é a Corte Constitucional brasileira, através da análise da compatibilidade de uma lei ou ato normativo com a Constituição Federal, por um processo objetivo em que não há partes, apenas legitimados ativo e passivo.

O STF, por exemplo, quando julga procedente o pedido formulado em uma ADIn, declarando uma lei inconstitucional, traz para o ordenamento jurídico uma grave consequência: a ineficácia total ${ }^{45}$ daquela lei. Porém, para tanto, o STF deverá realizar todo um trabalho complexo de pesquisa e estudo que culminará no desenvolvimento argumentativo de uma tese jurídica a ser aplicada no caso. Esse esforço em trazer a melhor decisão

44 MARTINS, Ives Gandra; MENDES, Gilmar Ferreira. Controle Concentrado de Constitucionalidade: comentários à Lei no 9.868, de 10-11-1999. São Paulo: Saraiva, 2001, pp. 543-546.

45 A Lei 9.868/99, art. 28, traz a possibilidade de modulação temporal dos efeitos, de forma que o STF tem a prerrogativa de decidir a partir de quando sua decisão valerá, podendo optar por qualquer momento, o momento de promulgação da lei (efeitos ex tunc), um momento entre a promulgação e a decisão (efeitos retroativos), o momento da publicação da decisão (efeitos $e x$ nunc), ou um momento posterior ao da publicação da decisão (efeitos pró-futuro). 
para caso pode ser notado em muitos acórdãos, pela leitura dos votos individuais de cada Ministro. Esse trabalho não merece ser simplesmente descartado, de forma a obrigar os Ministros a se manifestarem repetidas vezes sobre o mesmo assunto no mesmo sentido.

Na verdade, vemos que a análise feita pelo STF sobre determinado diploma legal é voltada para a norma que ele contém. Por isso, quando o STF julga, por exemplo, a lei X materialmente inconstitucional, ele está afirmando que a norma trazida pela lei $\mathrm{X}$ é inconstitucional, a norma contida na lei $\mathrm{X}$ não pode conviver com a Constituição Federal. Ora, qualquer outra lei que tenha o mesmo conteúdo, seja ela denominada lei $\mathrm{W}$, lei Y, lei Z, será igualmente inconstitucional enquanto a Constituição não for modificada.

Por isso, como o STF, em controle concentrado de constitucionalidade, analisa a norma contida na lei, essa análise deve ser mantida para todas as demais situações. Dessa forma, atribuição de efeito vinculante apenas ao dispositivo do acórdão do STF seria um erro. A declaração da inconstitucionalidade do hipotético decreto estadual 123, por exemplo, seria irrelevante se qualquer juiz pudesse utilizar como razão de decidir uma portaria de uma secretaria estadual, de idêntico teor, reconhecendo-a como constitucional. Porém, entendendo-se que os motivos determinantes também vinculam, um juiz deveria considerar a norma contida no decreto estadual como sendo inconstitucional, de forma que qualquer outro instrumento dotado de normatividade também deveria ser considerado inconstitucional pelo juiz de primeiro grau, sob pena de desafio à autoridade da decisão do STF, a ensejar o cabimento da Reclamação.

Portanto, o STF ao analisar uma questão constitucional extrai, a partir de sua interpretação da Constituição Federal, uma norma que se aplicará à situação. Se a lei analisada no caso trouxer uma norma contrária à norma da Constituição ela será inconstitucional. Se não houver tal incompatibilidade, a lei será constitucional.

Por isso, o importante ao analisar os limites do efeito vinculantes das 
decisões do STF é encontrar a norma emergente do julgado. Mais adiante será abordado o conceito de holding, que é exatamente a extração da norma de um precedente. Sobre o assunto, Gilmar Ferreira Mendes e Ives Gandra da Silva Martins assim se pronunciam:

"Tal como acentuado, o caráter transcendente do efeito vinculante impõe
que sejam considerados não apenas o conteúdo da parte dispositiva da
decisão, mas a norma abstrata que dela se extrai, isto é, a proposição de
que determinado tipo de situação, conduta ou regulação - e não apenas
aquela objeto do pronunciamento jurisdicional - é constitucional ou
inconstitucional e deve, por isso, ser preservado ou eliminado." 46

Ao lado dessa discussão, pode-se também indagar quais seriam os limites subjetivos do efeito vinculante. De acordo com a redação da Constituição Federal, dada a partir da $\mathrm{EC} \mathrm{n}$ o 3/93, só são vinculados pelas decisões do STF os órgãos do Poder Executivo e do Judiciário, excetuando o próprio Supremo.

Ao STF é permitida a superação do precedente, através do overruling, que corresponderia à revogação total do precedente, e do overriding, que corresponderia à revogação parcial do precedente. Essa revogação poderá ser prospectiva, só abrangendo casos futuros, ou retroativa, de forma a abranger situações passadas e futuras.

Então, é claro que o STF poderá sempre reanalisar a questão já decidida, uma vez que ele mesmo não é abrangido pelo efeito vinculante. Caso contrário "além de contribuir para o congelamento do direito constitucional, tal solução obrigaria o Tribunal a sustentar teses que considerasse errôneas ou já superadas (...) isso poderia significar uma renúncia ao próprio desenvolvimento da Constituição, afazer imanente aos órgãos de jurisdição constitucional. "47

Sendo assim, a força dos precedentes se torna cada vez maior, o que faz com que o Judiciário participe ativamente da construção do Direito na sociedade. Por isso, é cada vez mais comum se ouvir falar na eficácia transcendente dos motivos determinantes das decisões do STF, pois busca- 
se estender o efeito vinculante também aos fundamentos das decisões do STF, como forma de promover o maior e mais rápido desenvolvimento do Direito Constitucional, garantindo máxima eficácia aos precedentes vinculantes da Suprema Corte.

\title{
4.1. Vantagens da aplicação da teoria:
}

É de inquestionável utilidade a aplicação da teoria da transcendência dos motivos determinantes, apesar de alguns autores se levantarem contra $\mathrm{ela}^{48}$, tendo em vista as vantagens que ela traz à ordem jurídica brasileira.

Com a maior abrangência do efeito vinculante, muitos princípios constitucionais a ele associados também seriam efetivados de modo mais amplo. O efeito vinculante das decisões do STF atende a diversos princípios constitucionais, como o princípio da segurança jurídica, da isonomia, da celeridade processual, dentre outros.

A efetivação desses princípios constitucionais tem sido o grande argumento dos defensores da tese. Nesse sentido, destaca Patrícia Perrone Campos de Mello:

\begin{abstract}
"os principais argumentos em defesa da eficácia transcendente da motivação se ligam a uma abordagem teleológica e sistemática do fenômeno. Em primeiro lugar, no que respeita a seus aspectos finalísticos, a adoção de precedentes normativos se justifica na medida em que se busca promover alguns valores que lhe são correlatos, a saber: a segurança e a previsibilidade jurídica; a uniformidade do direito e a isonomia entre os cidadãos; a credibilidade das cortes; a redução de litígios; e a preservação da força normativa da Constituição, em virtude do respeito à autoridade da exegese produzida pelo STF."
\end{abstract}

Pelo princípio da segurança jurídica, os particulares têm o direito de saber como funciona o sistema jurídico do País para que se ajustem e planejem suas atitudes de forma melhor diante de qualquer situação. Dessa forma, a estabilidade das relações jurídicas deve ser contemplada pelo Poder Judiciário para atender a esse princípio.

Isso porque não basta haver uma lei ou outra norma conferindo

48 FERNANDES, André Dias. Eficácia das decisões do STF em ADIN e ADC. Efeito vinculante, coisa julgada erga omnes e eficácia erga omnes. Salvador: Jus Podivm, 2009.

49 MELLO, Patrícia Perrone Campos. Op. cit., p. 162. 
direitos e impondo obrigações aos particulares, mas é necessário que se conheça também a interpretação que os Tribunais darão a essa norma. Somente conhecendo a forma como o direito é aplicado diariamente os cidadãos podem programar suas vidas, seus negócios etc.

Por isso, em virtude da eficácia transcendente dos fundamentos das decisões do STF, as razões de decidir expostas pelo Supremo em seus acórdãos também devem ser dotadas de efeito vinculante. Isso evitaria que cada juiz ou Tribunal do País tenham a possibilidade de ignorar os pronunciamentos do Supremo, posicionando-se contrariamente a eles. Se as pessoas pautam suas vidas e atitudes pelas decisões da Corte Suprema, tais decisões não podem ser desrespeitadas por outros órgãos do mesmo Poder, mas antes devem ter a maior eficácia possível.

A teoria da transcendência dos motivos determinantes traria proteção especial ao aspecto objetivo ${ }^{50}$ do princípio da segurança jurídica, pois a estabilização das relações jurídicas torna imprescindível a uniformidade de tratamento da matéria constitucional pelo Judiciário e, para que se alcance tal uniformidade, é preciso que as decisões do STF em sede de controle concentrado de constitucionalidade tenham não só efeito vinculante em relação ao seu dispositivo, mas também em relação aos seus motivos determinantes.

Além disso, a teoria busca também efetivar o princípio da celeridade processual, pois, sem que seja cabível Reclamação contra decisões de instâncias inferiores que contrariem as decisões das Cortes Superiores, para que o particular chegue até as instâncias superiores será necessário percorrer um longínquo e demorado caminho. O efeito

50 José dos Santos Carvalho Filho traz a dicotomia entre o aspecto objetivo e o subjetivo do princípio da segurança jurídica: "No direito comparado, especialmente no direito alemão, os estudiosos se têm dedicado à necessidade de estabilização de certas situações jurídicas, principalmente em virtude do transcurso do tempo e da boa-fé, e distinguem os princípios da segurança jurídica e da proteção à confiança. Pelo primeiro, confere-se relevo ao aspecto objetivo do conceito, indicando-se a inafastabilidade da estabilização jurídica; pelo segundo, o realce incide sobre o aspecto subjetivo, e neste se sublinha o sentimento do indivíduo em relação a atos, inclusive e principalmente do Estado, dotados de presunção de legitimidade e com a aparência de legalidade" (FILHO, José dos Santos Carvalho. Manual de Direito Administrativo, $21^{\text {a }}$ edição, Rio de Janeiro: Lumen Juris, 2009, p. 34). 
vinculante, ao lado da previsão da Reclamação, torna a prestação jurisdicional mais acessível aos cidadãos.

Sabendo-se qual é o entendimento do STF, não tem porque um juiz de primeira instância julgar contrariamente a esse entendimento, pois obviamente um recurso desta decisão seria provido, reformando-se ou anulando-se tal decisão. Para evitar que os jurisdicionados lancem mão da tutela recursal para impugnar tais decisões é que foi criado o efeito vinculante.

Luís Roberto Barroso também se mostra favorável a esse entendimento, ao falar sobre o papel conferido pela Constituição Federal, art. 52, $\mathrm{X}$ ao Senado Federal no que diz respeito ao controle incidental de constitucionalidade:

"Seria uma demasia, uma violação ao princípio da economia processual, obrigar um dos legitimados do art. 103 [da CRBF/88] a propor ação direta para produzir uma decisão que já se sabe qual é!"

Com a adoção da teoria da transcendência dos motivos determinantes, por exemplo, uma decisão que julgou improcedente ADIn que questionava uma lei estadual de Rondônia, por entender o STF que a Assembleia Legislativa daquele Estado tinha realmente a competência para legislar sobre a matéria, vincula o Tribunal de Justiça de Santa Catarina, que não poderá declarar uma lei de idêntico teor, editada em situação semelhante, formalmente inconstitucional, por entender que a matéria deveria ser tratada por decreto executivo. Caso isso não fosse observado, uma Reclamação levaria a questão ao STF, que poderia rapidamente cassar a decisão para defender a autoridade de sua decisão.

É de suma importância para o desenvolvimento social e econômico do País que questões jurídicas tenham rápida apreciação pelo Judiciário. Para isso, é essencial a presença de determinados instrumentos que limitem o número de processos que chegam à Corte Constitucional. O efeito

51 BARROSO, Luís Roberto. O controle de constitucionalidade no direito brasileiro: exposição sistemática da doutrina e análise crítica da jurisprudência. $2^{\mathrm{a}}$ edição, revista e atualizada. São Paulo: Saraiva, 2007, p. 111. 
vinculante se reveste dessa característica e a sua eficácia transcendente aos fundamentos determinantes busca aumentar o seu potencial, para que o art. $5^{\circ}$, LXXVIII não se torne letra morta na Constituição Federal: “a todos, no âmbito judicial e administrativo, são assegurados a razoável duração do processo e os meios que garantam a celeridade de sua tramitação”.

Por fim, o maior proveito trazido pela teoria da transcendência dos motivos determinantes é a maior efetivação do princípio da isonomia. Sem a aplicação da teoria, seria possível haver ofensa a este princípio, pois dois cidadãos na mesma situação poderiam receber tutelas jurisdicionais diversas. Basta pensar em leis de dois Estados diversos da federação, tendo sido uma delas declarada inconstitucional pelo STF e tendo sido a outra, posteriormente à decisão do STF, aplicada por juízes de instâncias inferiores. Não sendo cabível a Reclamação nesse caso, somente o Recurso Extraordinário, com seu iter extremamente moroso, poderia resolver a situação de um jurisdicionado afetado por esta lei estadual que ainda não foi declarada inconstitucional.

Portanto, a aplicação da teoria resolveria um problema intrínseco ao próprio sistema de controle de constitucionalidade adotado pelo Brasil. Como o Brasil é uma República Federativa, em que cada Estado tem sua autonomia legislativa delimitada pela Constituição Federal, a interpretação desses limites deve ser observada pelo Legislativo de todos os Estados. A adoção do modelo difuso de controle de constitucionalidade ao lado do modelo concentrado, em que somente o último tem efeito vinculante e eficácia erga omnes, torna imperioso que as decisões vinculantes do STF sejam plenamente observadas, para que a isonomia entre os cidadãos de todo o País seja realmente verificada. A adoção da teoria da transcendência dos motivos determinantes, em última análise, impede que qualquer juiz ou tribunal, em controle difuso de constitucionalidade, julgue contrariamente ao que o STF decidiu em determinado caso, ainda que se trate de um caso regional. A interpretação da Constituição sempre deve ser tratada como matéria de relevância nacional. 
Para que haja verdadeira igualdade entre os jurisdicionados, é preciso que as decisões do STF sejam inteiramente respeitadas pelas instâncias inferiores do Judiciário.

\subsection{Vertente não democrática da teoria:}

Apesar de trazer vantagens, a teoria da transcendência dos motivos determinantes também apresenta algumas desvantagens. A mais contundente delas é o possível enfraquecimento do debate democrático, uma vez que a aplicação da teoria serviria para aumentar a concentração de poderes no Judiciário.

O Brasil é um Estado Democrático de Direito, em que todo poder é exercido pelo povo, normalmente por meio de representantes eleitos. Isso é verificado muito claramente nas funções do Poder Legislativo, no qual a maioria dos membros são eleitos diretamente, e nas funções do Poder Executivo, no qual, apesar de a maioria de seus membros não serem eleitos, grande parte deles são escolhidos pelo Chefe do Poder Executivo, este sim eleito diretamente pelo povo.

Entretanto, a função exercida pelo Poder Judiciário não é dotada dessa veia democrática. Isso porque seus membros não são eleitos pelo povo, mas chegam a ocupar seus cargos através de concurso público de provas e títulos, na forma do art. 93, I, CRFB/88, ou de indicação do Poder Executivo, na forma do art. 94, CRFB/88. Em relação aos ocupantes dos cargos das instâncias superiores ${ }^{52}$ do Judiciário, são nomeados pelo Presidente da República após aprovação do Senado Federal os Ministros do STF (art. 102, parágrafo único, CRFB/88), do STJ (art. 104, parágrafo

52 A escolha dos Ministros do TSE é diferente e está prevista no art. 119, que diz:

Art. 119. O Tribunal Superior Eleitoral compor-se-á, no mínimo, de sete membros, escolhidos: I - mediante eleição, pelo voto secreto:

a) três juízes dentre os Ministros do Supremo Tribunal Federal;

b) dois juízes dentre os Ministros do Superior Tribunal de Justiça;

II - por nomeação do Presidente da República, dois juízes dentre seis advogados de notável saber jurídico e idoneidade moral, indicados pelo Supremo Tribunal Federal.

Parágrafo único. O Tribunal Superior Eleitoral elegerá seu Presidente e o Vice-Presidente dentre os Ministros do Supremo Tribunal Federal, e o Corregedor Eleitoral dentre os Ministros do Superior Tribunal de Justiça. 
único, CRFB/88), do TST (art. 111-A, CRFB/88) e do STM (art. 123, CRFB/88). Algumas raras exceções dão aos cidadãos a possibilidade de exercerem diretamente a função jurisdicional (art. 5, XXXVII, CRFB/88).

Nesse ínterim, irrompe uma questão crucial: seria constitucional, em respeito ao princípio democrático, permitir que um órgão cujos integrantes não são eleitos pelo povo tenha tão grandes poderes no que concerne à jurisdição constitucional?

A resposta só pode ser positiva. Aliás, foi a própria Constituição que delimitou as características e as incumbências do Judiciário. Além disso, a guarda da Constituição Federal é atribuição do Supremo Tribunal Federal (CRFB/88, art. 102).

Apesar de os membros do Judiciário não serem eleitos, isso não significa que toda e qualquer atuação dos juízes e tribunais seja antidemocrática. Pelo contrário, num Estado Democrático de Direito é essencial que sejam resguardados os direitos das minorias. Essas minorias, que talvez não consigam representação no Congresso Nacional, têm seus direitos protegidos pelo Judiciário, que deve aplicar as leis emanadas do Legislativo interpretando-as segundo a Constituição, que, por sua vez, garante a isonomia material a todos os cidadãos.

O Poder Constituinte Originário é uma demonstração soberana do poder do povo. A Constituição de 1988 se mostra especialmente preocupada com as minorias, fato facilmente observado pela simples leitura de passagens que trazem direitos e garantias fundamentais, como os artigos $5^{\circ}$, $6^{\circ}$ e $7^{\circ}$, dentre outros. A liberdade de religião, liberdade de expressão, a isonomia material, a liberdade de associação etc. são exemplos de que a Assembleia Constituinte de 1987/88 se preocupou com os direitos das minorias e procurou protegê-los inclusive de futuras manifestações do Poder Constituinte Derivado, como se observa no art. $60, \S 4^{\circ}$, IV, da Constituição.

Quando o Judiciário, tendo a prerrogativa de interpretar a legislação infraconstitucional de acordo com as normas da Constituição, utiliza-se das 
garantias fundamentais para refrear possíveis abusos dos demais Poderes, que são democráticos por excelência, mostra-se também um órgão democrático, posto que defensor da Democracia.

Por isso, o controle de constitucionalidade perpetrado pelo Judiciário, mesmo tendo efeito vinculante sobre outros órgãos cujos membros são eleitos, é também uma expressão constitucional do princípio democrático. Porém, isso não afasta a discussão sobre a dificuldade contramajoritária ${ }^{53}$.

O Judiciário, como foi dito, opera por agentes públicos não eleitos, mas aprovados em concurso ou indicados, de forma que sua atuação sempre pode gerar discussões acerca da legitimidade democrática. Para atenuar esse problema e garantir um mínimo de legitimidade democrática às decisões judiciárias, principalmente às grandes questões constitucionais enfrentadas pelo STF, a legislação infraconstitucional tem previsto uma série de instrumentos que permitem aos cidadãos a manifestação de sua opinião aos Ministros antes de ocorrer o julgamento. São conhecidos exemplos a figura do amicus curiae e as audiências públicas (Lei 9.868/99, art. $7^{\circ}, \S 2^{\circ}$, art. $9^{\circ}$, $\S 1^{\circ}$, respectivamente).

Independente de sua efetividade, esses são exemplos de que o Direito brasileiro busca conferir maior legitimidade aos atos jurisdicionais, como forma de realização do princípio democrático.

Com efeito, o Judiciário é, ainda assim, considerado um Poder contramajoritário. Ele é o responsável por defender os interesses das minorias contra possíveis abusos das maiorias eventuais que tentem impor suas vontades através dos demais Poderes. Se um dia, por exemplo, houver mulheres em número muito superior aos homens, não poderiam parlamentares feministas abolir a igualdade entre homens e mulheres imposta pela Constituição (art. $5^{\circ}$, I) para conceder às mulheres mais

53 Alexander Bickel utiliza a expressão "countermajoritarian difficulty" para abordar o problema da legitimidade democrática do Judiciário, que, mesmo sem ter membros eleitos diretamente pelo povo, controla atos do Legislativo e do Executivo, cujos membros são eleitos diretamente pelo povo. 
direitos e privilégios do que aos homens. O Judiciário seria capaz de controlar atos desse tipo, declarando-os inconstitucionais.

Se todos os Poderes sofressem influência política direta do povo, provavelmente os direitos das minorias seriam afetados pelas vontades das maiorias transitórias.

Porém, apesar da dificuldade contramajoritária, vemos que o Judiciário tem sido cada vez mais importante na construção do Direito no Brasil. Não é raro que a decisão sobre assuntos cruciais para a sociedade brasileira se dê pela mão dos Ministros do Supremo Tribunal Federal. Como exemplo, podemos citar a pesquisa com células-tronco ${ }^{54}$, a progressão de regime em crimes hediondos ${ }^{55}$, a possibilidade da instituição de tributo para custeio da iluminação pública ${ }^{56}$, o reconhecimento da união estável entre pessoas do mesmo sexo ${ }^{57}$, dentre outras questões igualmente relevantes.

Todas essas questões são importantes para o País e deveriam ter sido decididas pelo Congresso Nacional, uma vez que se tratam de questões mais políticas do que jurídicas. Entretanto, verificou-se o contrário, pois quem teve a última palavra nesses assuntos foi o Poder Judiciário.

Contudo, não houve grandes manifestações sociais contra as decisões judiciais que definiram tais questões. Pelo contrário, foi observada grande aceitação popular das decisões do STF. Isso demonstra que o Poder Judiciário também é capaz de assumir questões políticas relevantes para a sociedade, atuando de forma democrática.

Apesar de o Judiciário padecer de falta de legitimidade democrática, a Constituição lhe atribuiu a importante missão de resguardar os interesses do povo através da interpretação da Constituição. Nos dizeres de Luís Roberto Barroso: “o Judiciário, ao interpretar as normas constitucionais, revela a vontade do constituinte, isto é, do povo, e a faz prevalecer sobre a

54 STF, ADIn 3510-DF, rel. Min. Carlos Ayres Britto, 29.05.2008.

55 STF, HC 82959-SP, rel. Min. Marco Aurélio, 23.02.2006.

56 Enunciado 670 da súmula da jurisprudência dominante no STF: "O serviço de iluminação pública não pode ser remunerado mediante taxa."

57 STF, ADIn 4277-DF, rel. Min. Carlos Ayres Britto, 05.05.2011. 
das maiorias parlamentares"

Além do Executivo e do Judiciário, a teoria acabaria, por fim, exercendo certa influência também sobre o Poder Legislativo. Pode-se tomar, por exemplo, a declaração de inconstitucionalidade de uma lei estadual no bojo de uma ADIn. Havendo uma lei de idêntico teor em outro Estado da Federação, caberia Reclamação contra decisão judicial que insistisse em aplicar tal lei sem demonstrar peculiaridades concernentes ao caso concreto.

Gilmar Ferreira Mendes e Ives Gandra da Silva Martins enfrentam este problema ao dizer:

"Segundo a doutrina dominante, são as seguintes as consequências do efeito vinculante para os não-partícipes do processo: (1) ainda que não tenham integrado o processo, os órgãos constitucionais estão obrigados, na medida de suas responsabilidades e atribuições, a tomar as necessárias providências para o desfazimento do estado de ilegitimidade; (2) assim, declarada a inconstitucionalidade de uma lei estadual, ficam os órgãos constitucionais de outros Estados, nos quais vigem leis de teor idêntico, obrigados a revogar ou a modificar os referidos textos legislativos." ${ }^{.59}$

Isso não quer dizer que o Poder Legislativo esteja vinculado pela decisão do STF. A Constituição Federal foi extremamente clara em apenas vincular o Executivo e o Judiciário (art. 102, $\S 2^{\circ}$ ). As Casas Legislativas sempre poderão reeditar leis de idêntico teor às leis declaradas inconstitucionais pelo STF e, dessa forma, reacender o debate acerca da questão constitucional. As alterações posteriores não são abrangidas pelo efeito vinculante.

Porém, o próprio STF tem feito com que o Legislativo leve em consideração a sua posição em relação a alguns temas constitucionais. Isso ocorreu, por exemplo, no julgamento das Ações Diretas de Inconstitucionalidade $\mathrm{n}^{\mathrm{o}} 2.797-2^{60}$ e $\mathrm{n}^{\mathrm{o}} 2.860-0^{61}$, em que o STF declarou inconstitucional a Lei 10.628/02, que acrescentou os parágrafos primeiro e

58 BARROSO, Luís Roberto (org.). A Nova Interpretação Constitucional: ponderação, direitos fundamentais e relações privadas. Rio de Janeiro: Renovar, 2003, p.55.

59 MARTINS, Ives Gandra; MENDES, Gilmar Ferreira. Op. cit., pp. 546-547.

60 STF, ADIn 2797-2-DF, rel. Min. Sepúlveda Pertence, 15.09.2005.

61 STF, ADIn 2860-0-DF, rel. Min. Sepúlveda Pertence, 15.09.2005. 
segundo ao art. 84 do Código de Processo Penal, tratando do foro por prerrogativa de função de ex-detentor de cargo público. Tal caso trouxe uma evolução na jurisprudência do STF.

Primeiramente, o STF entendia que o foro por prerrogativa de função se mantinha mesmo após a perda do cargo. O STF considerava que, após o fim do exercício da função pública, o processo continuava foro especial. Por exemplo, o fim do mandato eletivo do Presidente da República não implicava o fim do foro por prerrogativa de função no STF. Esse entendimento era, inclusive, sumulado $^{62}$. O STF conferia prevalência à proteção da atuação do autor, de forma que o foro se mantinha, ainda que o ato não tivesse sido praticado no exercício da função.

Porém, o STF mudou de orientação e passou a entender que o fim do exercício da função pública implica o fim do foro por prerrogativa de função, ou seja, o processo deve ser transferido para a instância competente do momento atual. Portanto, no entendimento do STF, não há foro por prerrogativa de função de ex-detentor de cargo público.

Depois dessa decisão do STF, foi aprovada a Lei 10.628/02, que introduziu os parágrafos primeiro e segundo ao art. 84 do Código de Processo Penal, para dizer que se mantinha o foro por prerrogativa de função ao término do mandato, na hipótese de o ato ter sido praticado no exercício da função. Então, nesse caso, o Congresso aprovou uma lei contrária à jurisprudência do STF.

O STF já havia decidido que o foro por prerrogativa de função cessaria juntamente com o término do exercício da função pública. Esta lei introduziu estes dispositivos com previsão diametralmente oposta. Então, o STF declarou esses dispositivos inconstitucionais, afirmando que a jurisprudência constitucional do STF só pode ser modificada pelo Congresso Nacional através da edição de Emenda Constitucional, nunca

62 Enunciado 394 da súmula da jurisprudência dominante no STF: "Cometido o crime durante o exercício funcional, prevalece a competência especial por prerrogativa de função, ainda que o inquérito ou a ação penal sejam iniciados após a cessação daquele exercício”. Este enunciado foi cancelado. 
pela edição de lei ordinária ou complementar.

O STF chegou a dizer que lei que altere sua interpretação constitucional apresenta vício de inconstitucionalidade formal. Se a jurisprudência do Supremo for sobre matéria constitucional, sobre interpretação constitucional, a superação só pode ser por Emenda. Entretanto, tratando-se de jurisprudência do STF acerca de interpretação do direito infraconstitucional, nada impede que ela seja alterada por lei. Parece fundamental verificar que tipo de norma o STF examinou em seu precedente, constitucional ou infraconstitucional.

Isso faz sentido, uma vez que, se o STF admitir que o Congresso Nacional altere sua jurisprudência constitucional por lei, todas as suas decisões estarão sujeitas a uma espécie de referendo do Congresso Nacional. Isso seria uma grande ofensa ao princípio da separação de poderes (ou de funções).

Entretanto, se o Congresso Nacional alterar a norma constitucional, por Emenda Constitucional, não estará corrigindo o Supremo, mas modificando a Constituição Federal e permitindo que um novo entendimento surja sobre o assunto.

Porém, a edição de uma lei contrária à jurisprudência do STF não deve ser vista como um descumprimento, um desafio à decisão do STF, mas como uma reabertura do debate constitucional. Ou seja, é um convite ao STF para se pronunciar novamente sobre a questão. Nada impede que essa lei seja questionada por uma ADIn, podendo o STF declará-la inconstitucional.

Por outro lado, se o Congresso edita uma Emenda Constitucional tratando do assunto, naturalmente deverá haver uma mudança de entendimento no STF, já que o parâmetro de aferição da constitucionalidade foi modificado. O que antigamente era contrário à Constituição Federal agora não mais é, porque seu texto foi modificado.

É claro que, havendo ofensa aos limites ao poder de reforma do constituinte derivado, o STF poderá declarar a inconstitucionalidade, 
inclusive, da Emenda Constitucional. Porém, a tendência é de o STF ser muito mais cauteloso quando a questão é reafirmada pelo Congresso em sede de Emenda, uma vez que a aprovação da Emenda requer maior consenso dentro da Casa Legislativa federal.

Essa é uma questão que transcende o plano jurídico e vai para o plano político. Tal discussão buscar definir quem tem a última palavra na interpretação da Constituição Federal, o STF ou o Congresso Nacional, uma vez que tanto o órgão do Judiciário quanto o órgão do Legislativo têm a função de obedecer e interpretar a Constituição. A resposta mais apropriada é: nenhum dos dois. Deve haver um diálogo para se chegar a um consenso. Não se pode dizer que é o Judiciário, porque haveria violação da democracia. Também não se pode dizer que é o Congresso Nacional, pois a atividade legislativa deve ser pautada pela Constituição Federal, especialmente pelos limites impostos pelas cláusulas pétreas (art. 60, $§ 4^{\circ}$ ).

A força da Emenda Constitucional é muito maior do que a de uma lei ordinária, porque para o STF declarar inconstitucional uma Emenda não basta dizer que ela é contrária à Constituição Federal, mas tem que afirmar que ela é contrária a uma cláusula pétrea. Isso exige uma fundamentação mais consistente.

Todavia, a jurisprudência do STF a esse respeito se mostra vacilante. Em outro caso ${ }^{63}$, envolvendo a aposentadoria especial para professores, o STF decidiu de forma diversa. Era jurisprudência sumulada do $\mathrm{STF}^{64}$ que a aposentadoria especial do professor só se aplicaria à atividade docente, considerada como tal apenas a atividade de ministração de aulas. Ou seja, o servidor só poderia contar o tempo especial ${ }^{65}$ pelo tempo dedicado dentro de sala de aula. Atividades externas, como pedagogia e diretoria, não poderiam ser consideradas. O STF fazia uma interpretação restritiva da Constituição.

63 STF, ADIn 3772-DF, Rel. Min. Carlos Britto, 29.10.2008.

64 Enunciado 726 da súmula da jurisprudência dominante no STF: "Para efeito de aposentadoria especial de professores, não se computa o tempo de serviço prestado fora da sala de aula".

65 Este tempo é de 30 anos para homens e de 25 anos para as mulheres, de acordo com a CRBF/88, art. $40, \S 1^{\circ}$, III, “a”, $\S 5^{\circ}$. 
Posteriormente, foi editada a Lei 11.301/06, que acrescentou o parágrafo segundo ao art. 67 da Lei. 9.394/96, prevendo que a expressão constitucional "funções de magistério" (art. 40, § 5, CRFB/88) significava não só a atividade docente, mas também tarefas administrativas e pedagógicas dentro da escola. Essa lei propôs uma interpretação àquela expressão constitucional mais ampliativa que a do STF.

Nesse caso, para manter a sua lógica, o STF deveria dizer que a lei tinha um vício de inconstitucionalidade formal, pois superava interpretação constitucional do STF. Porém, o STF afastou o argumento da inconstitucionalidade formal e reinterpretou a norma constitucional, usando a nova lei como uma oportunidade para reinterpretar a expressão constitucional "funções de magistério". O STF propôs uma interpretação conforme a Constituição dizendo que professores, no desempenho de atividades docentes, pedagógicas e administrativas, têm direito à aposentadoria especial.

Tanto num caso, como em outro, operou-se uma mutação constitucional, que se propagou por meio da atividade legislativa. O legislador provocou o STF a adotar uma nova interpretação constitucional. Porém, no caso do foro por prerrogativa de função, o STF não aceitou a iniciativa legislativa e, no caso da aposentadoria especial de professores, ele aceitou. A vantagem teórica de tratar isso como mutação constitucional, não como vício de inconstitucionalidade formal, é que a Constituição não fica engessada, permitindo-se que o Poder Legislativo também interprete o texto constitucional.

O fato de o STF ser casuístico também pode ser benéfico. Não seria bom, no Brasil, afirmar que o Congresso só pode mudar interpretação do STF através de Emenda Constitucional. Na Constituição há muitas expressões que comportam diferentes interpretações. O Congresso pode ter uma visão diferente da do STF sobre algumas dessas expressões. É de suma importância que haja diálogo entre os Poderes Legislativo e Judiciário. A ordem jurídica constitucional precisa que as questões importantes para o 
País sejam debatidas e decididas em conjunto pelos órgãos políticos e jurídicos.

Também vale ressaltar que o efeito vinculante das decisões do STF "contém implicitamente a cláusula rebus sic stantitbus, tendo sua atuação condicionada à permanência do estado de fato e de direito existentes à época da prolação da decisão"66. Isso quer dizer que qualquer modificação nessas circunstâncias poderia significar uma dessemelhança entre causas a autorizar o afastamento da decisão do STF no caso concreto ${ }^{67}$.

Por fim, surge outro problema, dessa vez em relação ao próprio Judiciário. Isso porque, na medida em que um precedente do Supremo tem a capacidade de influenciar a decisão de um juiz de primeira instância, este juiz passa a ter uma limitação em sua liberdade de julgar.

Como visto, no caso do efeito vinculante, diferentemente do que ocorre com a coisa julgada erga omnes, o juiz não está dispensado de decidir por haver uma decisão anterior do STF, mas tem o dever de decidir e sua decisão deve ser conforme o entendimento proferido pelo STF no precedente vinculante. Nas palavras de André Dias Fernandes:

\begin{abstract}
"Assim como o ato do juiz não deixa de ser decisório quando simplesmente cumpre o comando legal ao qual está vinculado, o ato do juiz não deixa de ser decisório quando cumpre o comando derivado do efeito vinculante de decidir em sentido idêntico ao decidido pelo STF. Por igual, a autoridade administrativa, subordinada ao princípio da legalidade, quando edita ato administrativo vinculado, não deixa de emitir ipso facto ato de cunho decisório." ${ }^{68}$
\end{abstract}

Porém, a liberdade judicial não é totalmente tolhida, uma vez que os juízes e tribunais de graus de jurisdição inferiores podem decidir de forma diversa. Para isso, eles devem demonstrar em sua fundamentação que a decisão do STF não se aplica ao caso, diante de suas peculiaridades. Esta é uma das formas de afastar o precedente vinculante que se chama

\title{
distinguish.
}

66 FERNANDES, André Dias. Op. cit., p. 185.

67 "Tal como a coisa julgada, o efeito vinculante refere-se ao momento da decisão. Alterações posteriores não são alcançadas." (MENDES, Gilmar Ferreira. Controle de constitucionalidade: aspectos jurídicos e políticos. São Paulo: Saraiva, 1990, p. 339).

68 FERNANDES, André Dias. Op. cit., pp. 172-173. 
O distinguish é a chamada técnica de distinção. Tal técnica consiste, nas palavras de Celso de Albuquerque Silva, em “criar uma exceção à regra geral na medida em que, como o caso que atualmente se decide se encontra por ela abrangido, deveria ser, mas de fato não é por ela alcançado" ${ }^{, 69}$.

Dessa forma, é possível afirmar que o distinguish permite a análise das peculiaridades do caso concreto pelo juiz que o julgará, devendo ele adotar o posicionamento do precedente vinculante do STF se se tratar de um caso semelhante, mas tendo também o dever de recusar a aplicação do precedente se algo de novo ou diferente fizer necessário que outra posição seja adotada, de forma a fazer a justiça prevalecer.

É importante observar que o distinguish é diferente das técnicas de superação dos precedentes abordadas anteriormente, overruling e overriding. Como ressalta Alexy:

"A técnica de distinguir é usada onde a norma a ser observada do ponto de vista da lei casual é entendida tão estritamente - por exemplo, através da introdução de uma característica não presente nos fatos do caso - que ela não mais se aplica. Neste processo vale a pena continuar considerando o precedente como tal. Ao contrário, a técnica de prevalecer consiste na rejeição do precedente. Aqui, só um ponto de interesse: tanto a distinção quanto o prevalecimento requerem justificação". ${ }^{70}$

Ao não aplicar a decisão do STF por julgá-la inaplicável ao caso, o juiz está julgando a aplicabilidade da decisão do STF ao caso concreto, não revendo o mérito da decisão proferida pelo Supremo. Isso faz toda a diferença e demonstra de forma inequívoca a imprescindibilidade dos juízes até mesmo para a resolução de casos sobre os quais o STF já se pronunciou. Se o juiz de primeira instância pudesse decidir de forma contrária ao precedente vinculante do STF, tal precedente não seria verdadeiramente vinculante. Por outro lado, se o juiz não tivesse liberdade para julgar casos diferentes dos casos abrangidos pelo precedente do STF, o efeito vinculante seria maior do que o previsto pelo legislador, e isso acabaria subvertendo a

69 SILVA, Celso de Albuquerque. Do efeito vinculante: sua legitimação e aplicação. Rio de Janeiro: Lumen Juris, 2005, p. 247.

70 ALEXY, Robert. Teoria da argumentação jurídica. Trad. Zilda Hutchinson. São Paulo: Landy, 2001, p. 262. 
justiça, pois o precedente do STF seria erroneamente utilizado em casos nos quais o STF talvez tivesse decidido de outra forma, em razão de suas peculiaridades. Ao tratar sobre o tema, André Dias Fernandes assevera:

"Ademais, o juiz sempre terá liberdade para decidir sobre a aplicabilidade ou não da decisão do STF ao caso concreto que tem diante de si, i.e., para decidir se é juridicamente possível e adequada a extensão da decisão do STF ao caso concreto. A possibilidade de cassação da sua decisão mediante reclamação não infirma esse poder-dever do juiz, porquanto aquela só se dará se o juiz não exercer corretamente o seu poder-dever: a reclamação só será julgada procedente se o juiz deixar de estender ao caso a decisão do STF aplicável, se estender ao caso decisão do STF inaplicável ou se estender ao caso de forma indevida a decisão do STF aplicável, e nunca pelo simples fato de o juiz ter exercido juízo sobre a aplicabilidade ou não da decisão do STF (cfr., analogicamente, art. 103A, $\S 3^{\circ}$, da CF-88).",

Para que essa técnica de distinção seja adotada pelo juiz diante de um caso concreto, deve haver minuciosa análise das razões de decidir que determinaram a norma emergente do precedente vinculante. Ao tratar da aplicação do distinguish em relação às súmulas vinculantes, afirma André Dias Fernandes:

\footnotetext{
"[as] circunstâncias fático-jurídicas e a própria rationale de tais súmulas correm o risco de ser esquecidas em virtude da "canonização" do enunciado da súmula vinculante, que passaria a ter uma indevida existência autônoma em relação àquelas, como se o enunciado sumular, assim petrificado, existisse por si mesmo." ${ }^{, 72}$
}

Por isso, é importante que o precedente seja sempre questionado antes de ser aplicado. A aplicação inadvertida de um precedente sem a análise dos fundamentos que o fizeram surgir no ordenamento é prejudicial à justiça, pois impede que os detalhes de cada caso concreto sejam considerados pelo juiz no momento do julgamento.

De fato, o efeito vinculante transfere aos demais órgãos judiciários o ônus argumentativo da questão. Isso quer dizer que, se o juiz achar que a decisão do STF não se aplica ao caso, ele poderá afastá-la, mas deverá se esforçar para trazer argumentos em sua fundamentação que convençam toda a sociedade e as instâncias superiores de que a decisão do STF não é 
aplicável àquele caso específico que julga. Nas precisas palavras de Patrícia Perrone:

\begin{abstract}
"Os países que adotam o stare decisis não desconhecem que os processos decisórios são argumentativos, valorativos e mesmo ideológicos. Acreditam, contudo, que essa política reduz a liberdade judicial, na medida em que, ainda que não anule a subjetividade do magistrado, lhe confere um ônus argumentativo crescente para se afastar das regras já estabelecidas, para reformulá-las convincentemente, para excepcioná-las, quando buscar, com isso, projetar suas próprias convicções na decisão de um caso." 73
\end{abstract}

Tendo isso em vista, podemos afirmar que a aplicação da teoria da transcendência dos motivos determinantes, por um lado, agravaria o quadro da dificuldade contramajoritária, mas por outro fortaleceria a ordem constitucional. O problema da falta de legitimidade democrática seria ampliado, pois haveria o aumento do âmbito vinculante das decisões do STF em controle abstrato de constitucionalidade, já que o efeito vinculante não vincula somente os demais órgãos do Poder Judiciário, mas também os órgãos da Administração Pública. Porém, isso não necessariamente seria algo negativo para o Direito brasileiro, uma vez que, como visto, haveria também um incremento na efetivação de diversos princípios constitucionais.

Dessa forma, não seria errado, para saber se a teoria da transcendência dos motivos determinantes deve ou não ser implementada no Brasil, realizar uma ponderação entre princípios constitucionais. Com a teoria, o princípio democrático seria lesado. Sem a teoria, haveria lesão aos princípios da segurança jurídica, da isonomia e da celeridade processual. Porém, como se mostrou, a aplicação da teoria traria tão grandes benefícios à ordem jurídica constitucional brasileira que a ausência de escolha democrática dos juízes poderia ser considerada um minus, uma lesão suportável e aceitável. A aplicação da teoria, sem dúvida, traz maiores bônus do que ônus à ordem jurídica. 


\subsection{Modo de aplicação da teoria:}

Admitindo-se a adoção da teoria, é necessário analisar como seu implemento se concretizaria. Em resumo, uma vez que os fundamentos integrem a parte vinculante da decisão, torna-se essencial a definição do âmbito vinculante do julgado. Para tanto, é pertinente abordar algumas questões relevantes acerca da hermenêutica constitucional.

A moderna doutrina constitucional tem definido a interpretação como o processo de elaboração da norma ${ }^{74}$. Podemos afirmar que os juízes e Tribunais produzem o Direito quando interpretam as normas jurídicas para julgar. Interpretar é fazer o Direito. Dessa forma, seria mais adequado pensar a norma jurídica como o resultado da produção jurisdicional partindo da interpretação de um diploma normativo (como uma lei ou um decreto). A norma é o resultado final da interpretação. Obtém-se a norma após a interpretação. Os juízes interpretam um dispositivo normativo e, assim, extraem dele a norma que será utilizada no caso concreto. A interpretação seria, partindo desse princípio, o processo de elaboração da norma.

O STF, por exemplo, ao decidir pela constitucionalidade da resolução do CNJ que vedou o nepotismo no âmbito do Poder Judiciário, partiu de um diploma normativo (a Constituição Federal, art. 37, caput, que traz os princípios da moralidade e da impessoalidade, dentre outros dispositivos) e, interpretando-o, chegou à norma que usaria para decidir o caso, qual seja, a utilização do poder de conceder empregos livremente na Administração Pública pelo administrador para colocar seus parentes no serviço público é evidente desvio de finalidade, afetando a moralidade administrativa e, dessa forma, a Constituição Federal. Tal norma não está expressa em lugar algum da Constituição nem em outro diploma normativo $^{75}$. Essa norma foi extraída de um diploma normativo pelo

74 ÁVILA, Humberto. Teoria dos Princípios: da definição à aplicação dos princípios jurídicos. $4^{\mathrm{a}}$ edição. São Paulo: Malheiros, 2004, p. 30.

75 Vale ressaltar que, posteriormente, esta norma jurídica advinda da interpretação constitucional restou positivada na Súmula Vinculante n ${ }^{\circ} 13$, que diz: "A nomeação de cônjuge, companheiro ou parente em linha reta, colateral ou por afinidade, até o terceiro grau, inclusive, da autoridade 
processo da interpretação constitucional.

É óbvio que esse processo de criação de normas pelos Tribunais por meio da interpretação não é um processo livre e discricionário. O Judiciário deve basear suas decisões em diplomas normativos criados pelo Legislativo ou pelo Executivo. Os limites da interpretação estão no próprio texto normativo tido como base pelo magistrado.

Há poucas hipóteses de o juiz fugir do texto normativo aplicável ao caso. Ele só poderá fazer isso se as circunstâncias do caso concreto exigirem outro tipo de interpretação que não a literal. Além disso, qualquer interpretação dada pelo magistrado a um texto normativo deve ser devidamente fundamentada, por respeito ao estabelecido na Constituição Federal, art.93, inciso IX ${ }^{76}$.

Nesse sentido, a teoria da transcendência dos motivos determinantes defende que o que deve ser alcançado pelo efeito vinculante da decisão do STF é a norma que se extrai dessa decisão, norma que se torna conhecida a partir da análise do dispositivo em conjunto com a fundamentação que conduziu à conclusão adotada pelo Supremo.

A doutrina ${ }^{77}$ tem chamado de holding (ou ratio decidendi) a norma que emerge do julgamento de um caso concreto. O Tribunal, diante do caso concreto, a partir da legislação a ele aplicável, formula a norma que guiará sua decisão embasando-a juridicamente. A norma que se extrai do que foi dito pelo Tribunal no caso e que o guiou ao caminho da decisão adotada será o holding.

A delimitação do holding é de grande dificuldade. Por um lado, o holding não pode ser muito abrangente, sob pena de se promover uma

nomeante ou de servidor da mesma pessoa jurídica investido em cargo de direção, chefia ou assessoramento, para o exercício de cargo em comissão ou de confiança ou, ainda, de função gratificada na administração pública direta e indireta em qualquer dos Poderes da União, dos Estados, do Distrito Federal e dos Municípios, compreendido o ajuste mediante designações recíprocas, viola a Constituição Federal."

$76 \mathrm{CF}$, art.93, IX: "todos os julgamentos dos órgãos do Poder Judiciário serão públicos, e fundamentadas todas as decisões, sob pena de nulidade, podendo a lei limitar a presença, em determinados atos, às próprias partes e a seus advogados, ou somente a estes, em casos nos quais a preservação do direito à intimidade do interessado no sigilo não prejudique o interesse público à informação; (Redação dada pela Emenda Constitucional n 45, de 2004)”.

77 MELLO, Patrícia Perrone Campos. Op. cit., p. 118. 
generalização indevida, fazendo a decisão ter um efeito vinculante maior do que o desejável. Por outro lado, não pode o holding ser muito restrito de forma a limitar o efeito vinculante a apenas alguns poucos casos.

De acordo com Patrícia Perrone Campos de Mello ${ }^{78}$, há 4 elementos que devem ser observados na delimitação do holding: os fatos relevantes do caso concreto, a questão posta em juízo, a fundamentação e o dispositivo. Todos esses elementos serão considerados na análise do que foi decidido pelo Tribunal, porém, nenhum elemento pode ser tomado destacadamente do outro. Na análise da semelhança entre as causas para a aplicação do julgado vinculante, se qualquer desses elementos destoar do conjunto, haverá uma causa distinta e, portanto, não vinculada ao precedente.

Ao ampliar o efeito vinculante aos fundamentos, fazendo com que eles sejam tão importantes para alcançar o holding quanto o dispositivo, deve-se delimitar também qual é a parte da fundamentação que deve entrar no holding.

Obviamente, não é tudo o que o juiz escreve entre o relatório e o dispositivo que pode ser considerado a sua fundamentação determinante no sentido de atribuir normatividade ao precedente. Por isso, diante de uma decisão judicial deve-se buscar extrair apenas os motivos que influenciaram diretamente a decisão do juiz naquela causa.

Diante de uma causa com duas ou mais razões de decidir determinantes apresentadas o juiz, deve-se analisar a relação entre elas e o dispositivo. Se as justificativas forem cumulativas, ou seja, se todas elas em conjunto determinarem a decisão do juiz, sendo que sem qualquer delas a decisão seria diferente, então todas elas deverão integrar o holding.

Se, ao contrário, o juiz apresentou duas ou mais razões, sendo que cada uma delas levaria à mesma conclusão a que o juiz chegou mesmo sem a presença das outras, estas seriam justificativas alternativas e cada uma delas constituiria um holding diferente e autônomo.

Se, finalmente, entre duas razões de decidir trazidas pelo juiz, uma 
delas se mostrar essencial à decisão proferida e a outra uma mera consideração marginal mencionada apenas para fortalecer a argumentação judicial, apenas aquela integrará o holding, gerando a normatividade. Esta será o chamado obter dictum.

Obter dictum é tudo aquilo que é trazido pelo tribunal na fundamentação de sua decisão, mas que não foi essencial para se chegar ao resultado obtido, constante no dispositivo. A única força que pode ser atribuída aos obter dicta é a persuasão, nada mais, pois não podem ser considerados como fundamentos determinantes da decisão.

Também podem ser considerados obter dicta os argumentos levantados por apenas um dos integrantes do órgão colegiado e não mencionado pelos demais, ou ainda aqueles trazidos por alguns membros e refutados pela maioria da Corte.

É claro que o que for obter dictum não pode integrar o holding da decisão. Apenas os motivos determinantes formarão o holding e terão efeito vinculante. O obter dictum valorizará o voto de quem o trouxe, servindo para ampliar o conhecimento dos operadores do Direito que a ele tenham acesso. Porém, não poderá ser considerado um motivo determinante.

Partindo dessas bases, para definir qual é a parte da decisão do STF em controle abstrato de constitucionalidade que realmente vinculará os demais órgãos do Poder Judiciário e a Administração Pública, o jurista deverá analisar o acórdão como um todo, buscando extrair da fundamentação e do dispositivo, em conjunto, um enunciado capaz de decidir a questão posta em juízo e outras semelhantes que, porventura, sejam futuramente ajuizadas. Este será o holding da decisão, a norma utilizada pelo Tribunal para decidir o caso, que constituirá a parte sobre a qual incidirá o efeito vinculante.

Diferentemente do que se possa pensar, o holding de determinado caso não pode ser visto como uma formulação estanque. Apesar de não se poder mudar o que consta de um acórdão publicado, a constante evolução do Direito traz a necessidade de mudanças nos posicionamentos dos 
Tribunais. Portanto, é admissível que casos subsequentes modifiquem o que restou decidido, de forma que o holding, consistente no posicionamento adotado pelo Tribunal em certo caso, vai se moldando, acrescentando, modificando gradualmente.

Essa situação é abordada por Patrícia Perrone Campos de Mello, que afirma:

\begin{abstract}
"As demandas subsequentes também promoverão o aperfeiçoamento do standard jurídico emergente de um acórdão. Nelas, as partes buscarão trazer novas versões do que restou decidido, interpretando o precedente de modo a que lhes favoreça. A partir de tais versões, travar-se-á um debate que busca esclarecer, distinguir ou reformular o holding. A rejeição de algumas teses, a aceitação de outras e a fundamentação desenvolvida para tal constituirão material para sua delimitação em demandas futuras. Por isso, pode-se dizer que a força normativa de um julgado se fortalecerá na medida em que novas decisões forem tornando mais determinado seu comando. Entretanto, o contrário também pode ocorrer. É possível que um holding se sujeite a tantas interpretações restritivas que reste completamente esvaziado." ${ }^{79}$ (grifos nossos)
\end{abstract}

Após descobrir qual é a parte da decisão do STF dotada de efeito vinculante, é necessário analisar em que situações esse efeito vinculante será observado. Para que os demais órgãos do Poder Judiciário e da Administração Pública estejam vinculados por uma decisão anterior do Supremo, é preciso que se verifique a similitude entre os casos. Somente em casos semelhantes a decisão anterior do STF deverá ser seguida.

Para os adeptos da teoria da transcendência dos motivos determinantes a semelhança entre 2 causas jurídicas a ensejar a utilização de um precedente dotado de efeito vinculante deve ser observada a partir da análise em conjunto dos fundamentos determinantes da decisão com o seu dispositivo. Após se definir qual é o holding emergente da decisão parâmetro, o juiz verificará se há ou não alguma circunstância fática ou de direito capaz de motivar suficientemente a não aplicação do precedente. Havendo tal circunstância, deve o juiz abordar o assunto em sua decisão, encarando o fato de existir um precedente do Supremo e expondo os motivos que o levaram a julgar de forma diversa.

79 Ibid., p. 139. 
Como já foi dito, se contra a decisão do juiz que desconsiderou o precedente vinculante por causa de uma peculiaridade do caso concreto for ajuizada Reclamação, esta deve ser julgada improcedente, apesar de o dispositivo do julgado claramente contrariar o que fora decidido pelo STF. Isso porque a Reclamação é o instrumento adequado para resguardar os precedentes vinculantes do STF em casos semelhantes. Em casos distintos, impera a liberdade do julgador.

No julgamento da Reclamação, se o STF considerar que a autoridade de sua decisão anterior foi afrontada, deverá abordar os exatos argumentos levantados pelo juiz para afastar o precedente e dizer, fundamentadamente, porque esses argumentos não configuram o distinguish. O STF terá o dever de demonstrar a similitude entre os casos, partindo da análise de seus fatos relevantes e da questão posta em juízo.

Isso ajuda, em última análise, a incrementar o debate constitucional acerca da questão jurídica discutida. Quando um juiz se depara com um caso que, à primeira vista, o precedente vinculante do STF seria aplicável, mas, por alguma peculiaridade, tal precedente deveria ser afastado, isso significa que o holding daquela decisão do STF era muito abrangente e deveria ser reformado, tornando-se mais restrito ou admitindo uma exceção.

Entretanto, a semelhança entre as questões não é facilmente verificada em todos os casos. Pode haver duas causas que versem sobre o mesmo dispositivo de um diploma normativo, mas que digam respeito a questões jurídicas distintas. Da mesma forma, apesar de a questão constitucional ser idêntica em duas causas distintas, pode ser que em uma delas haja um elemento fático que a diferencie, tornando imperioso o afastamento do precedente do STF. Mais uma vez o juiz estará em frente a uma causa em que a interpretação da decisão do Supremo será essencial.

Finalmente, antes de se enfrentarem os problemas práticos da aplicação da teoria da transcendência dos motivos determinantes, torna-se importante abordar um aspecto relevante da definição do âmbito de incidência do efeito vinculante das decisões do STF em controle 
concentrado de constitucionalidade.

Trata-se de crítica trazida por André Dias Fernandes, na qual ele aborda o risco da generalização indevida. Segundo o jurista, o julgador, diante do caso concreto, pode aduzir, como razão de decidir, premissas errôneas por serem generalizantes, ou seja, premissas que poderiam ser verdadeiras para determinado caso concreto, mas que não se aplicariam a outros casos. Isso é natural, uma vez que o julgador não pode prever todas as possibilidades de litígio que possam surgir no futuro. Uma fundamentação determinante que se mostrasse inverídica poderia fazer com que outros juízes, vinculados por tal decisão, não tivessem alternativa a não ser se submeter à decisão do Supremo e aceitá-la como que com força de lei. Os juízes de instâncias inferiores estariam, dessa forma, vinculados por um precedente trazido com base em uma motivação errada, contrária ao próprio Direito. Por isso, segundo o autor, o efeito vinculante das decisões do STF em controle concentrado de constitucionalidade deveria se ater ao dispositivo, já que o risco de haver tal generalização pela vinculação do dispositivo seria muito menor.

Veja-se um exemplo interessante trazido pelo jurista:

"Suponha-se, por exemplo, que, num processo objetivo, o STF declara a inconstitucionalidade de um decreto $\mathrm{X}$ sob o fundamento único de que este, em vez de simplesmente regulamentar uma lei existente, atuou como decreto autônomo, o que não é tolerado, em nenhuma hipótese, pela CF-88, já que esta não permite a edição de decreto que não seja para regulamentar o disposto em lei em sentido estrito. Na parte dispositiva do acórdão constará simplesmente que o STF declarou a inconstitucionalidade do decreto X.

Não há como negar que o fundamento determinante da decisão do STF, no exemplo acima, foi o de que a Constituição não autoriza em nenhuma hipótese a edição de decreto autônomo, até porque foi o único fundamento invocado no acórdão, não se podendo, portanto, qualificá-lo como um mero ober dictum.

Assim, de acordo com a tese da extensão dos efeitos vinculantes aos motivos determinantes, o juiz que tenha de examinar a constitucionalidade do decreto $\mathrm{Y}$ - que não trata de matéria similar à do decreto $\mathrm{X}$, mas sim de extinção de cargos públicos vagos no âmbito do Poder Executivo, nos termos do art. 84, VI, "b", da CF-88 -, acusado de atuar como decreto autônomo (isto é, de atuar com força de lei, sem regulamentar uma lei preexistente), estará vinculado ao fundamento determinante da decisão do STF, qual seja, o de que "a Constituição não autoriza em nenhuma hipótese a edição de decreto autônomo". Portanto, ver-se-ia obrigado, por força do efeito vinculante desse fundamento, a 
declarar a inconstitucionalidade do decreto $\mathrm{Y}$.

Ocorre que o decreto Y não é inconstitucional, pois consubstancia uma das hipóteses excepcionais de constitucionalidade do decreto autônomo, a saber, quando o decreto trata da extinção de cargos vagos no âmbito do Poder Executivo (CF-88, art. 84, VI, "b")! Mas o juiz observou o efeito vinculante do fundamento determinante da decisão do STF, visto como o decreto Y autônomo constituía um decreto autônomo e, como tal, perfeitamente enquadrável na premissa estabelecida pelo STF como fundamento determinante de sua decisão de que "a Constituição não autoriza em nenhuma hipótese a edição de decreto autônomo", sendo, portanto, para fins de efeito vinculante, uma questão análoga à decidida pelo STF." 80

Apesar de ser uma questão relevante sobre a adoção da teoria da transcendência dos motivos determinantes, tal crítica não tem embasamento sólido. Isso porque o argumento trazido por André Dias Fernandes para descartar o uso da teoria, pelo elevado risco de generalização indevida, se baseia em uma premissa falsa: os demais órgãos do Poder Judiciário estariam vinculados por uma fundamentação errada de uma decisão do Supremo dotada de efeito vinculante.

$\mathrm{Na}$ verdade, os demais juízes têm o dever de reagir a uma fundamentação errônea como é a do exemplo apresentado pelo jurista. Inclusive, uma fundamentação errada do STF dá ensejo ao distinguish, podendo, sim, os demais juízes e Tribunais decidir de forma diversa, demonstrando que a decisão do STF se fundou em premissa falsa ou ilógica.

Quanto ao tema, Celso de Albuquerque Silva destacou quais seriam as situações apropriadas para a utilização da técnica do distinguish:

"No modelo normativo forte os órgãos vinculados não podem limitar, restringir ou revogar o princípio formulado no caso precedente, ao qual devem estrita e rigorosa obediência, ressalvadas raras hipóteses em que podem se valer da técnica da distinção (distinguish). As exceções em que, atuando sob o modelo normativo forte, a Corte vinculada pode distinções, temperando e flexibilizando a aplicação da regra estabelecida no precedente vinculante são as seguintes: a) quando houver concorrência com outras regras derivadas de outros precedentes vinculantes ainda válidos; b) quando a regra se baseou em um claro e inadvertido erro; c) quando a corte vinculada se defrontar com situações que a corte vinculante claramente não queria abranger quando estabeleceu a regra; d) quando houver desenvolvimento posterior do direito. Essas

80 FERNANDES, André Dias. Op. cit., pp. 210-211. 
exceções são plenamente compatíveis com o modelo normativo forte porque são razões que permitem ao juiz se afastar da literalidade de um texto legislativo sem incidir em violação de seu conteúdo" ${ }^{81}$ (grifos nossos).

O próprio André Dias Fernandes cita essa passagem em sua obra, aduzindo que esse afastamento do efeito vinculante por um juiz seria semelhante ao afastamento, pelo mesmo, de uma lei, nas mesmas hipóteses, posto que o efeito vinculante "teria status equivalente ao da lei"

Portanto, em tais situações, o juiz vinculado pelo precedente teria o dever de ressaltar o erro cometido pelo STF em sua fundamentação e demonstrar que aquela fundamentação não se aplica ao caso concreto em apreço.

Isso não seria uma afronta à decisão do STF, pois não se estaria adentrando no mérito do que foi decidido pelo Supremo. O que haveria, nesses casos, seria a formulação de nova premissa com a qual o órgão judiciário trabalharia.

Com efeito, não é a mesma coisa afirmar que a decisão do STF não deve ser observada porque ela é ruim e afirmar que não deve ser observada porque se fundamentou em argumentos falaciosos. Nesta hipótese, estaria configurada evidente situação de distinguish, enquanto naquela o juiz estaria julgando de forma ilegítima, de forma a ensejar o cabimento da Reclamação.

81 SILVA, Celso de Albuquerque. Do efeito vinculante: sua legitimação e aplicação. Rio de Janeiro: Lumen Juris, 2005, p. 308.

82 FERNANDES, André Dias. Op. cit., 277. 


\section{Dificuldades da aplicação da teoria no Direito Brasileiro:}

Um dos grandes motivos da relutância, tanto da doutrina, quanto da jurisprudência, em adotar a teoria da transcendência dos motivos determinantes reside no fato de que ela seria de difícil aplicação nos moldes atuais do Direito brasileiro. A forma como os Tribunais, especialmente o STF, lidam com o direito em seus pronunciamentos evidencia que o Direito brasileiro talvez não esteja pronto para que os fundamentos determinantes das decisões vinculem os demais órgãos do Poder Judiciário e da Administração Pública.

Vemos algumas críticas levantadas tanto pela doutrina quanto pela jurisprudência que evidenciam que o tema merece tratamento específico.

A jurisprudência ${ }^{83}$ demonstrou preocupação em relação à viabilidade do STF, pois a adoção da teoria implicaria um aumento substantivo do número de Reclamações ao Supremo. Esta se mostra uma preocupação pertinente, pois, se tal temor se concretizasse, ao invés de resolver os problemas para os quais a teoria foi criada, sua adoção somente significaria uma substituição do meio processual utilizado atualmente para se chegar ao STF. Em outras palavras, o Supremo Tribunal Federal deixaria de julgar milhares de Recursos Extraordinários por ano e passaria a julgar milhares de Reclamações.

Além disso, se o número de Reclamações ajuizadas anualmente no STF se mostrasse de fato capaz de inviabilizar a atuação da Suprema Corte, haveria verdadeira ofensa à Constituição Federal, uma vez que a viabilidade do STF é considerada um princípio constitucional implícito, posto que necessário à efetiva atuação da Corte em suas competências, que lhe foram atribuídas pela própria Constituição ${ }^{84}$.

Esse tema foi suscitado pelo Min. Marco Aurélio, por ocasião de seu voto na Reclamação 1987:

83 STF, Rcl 1987-DF, Rel. Min. Maurício Corrêa, 01.10.2003.

84 MELlO, Patrícia Perrone Campos. Precedentes - $O$ desenvolvimento judicial do direito no constitucionalismo contemporâneo. Rio de Janeiro: Renovar, 2008, p. 164. 
"Indaga-se: Podemos avançar para admitir, de forma linear, a apresentação, a formalização de reclamação, tendo em conta que a Corte fulminou um ato normativo/ $\mathrm{O}$ que haverá, por exemplo, no campo tributário, se fulminada uma norma tributária, mesmo assim se partisse para a aplicação dessa norma? Admitiremos as reclamações dos contribuintes em geral? Como ficará esta Corte, tendo em conta os inúmeros processos que surgirão sob essa nomenclatura 'reclamação'? (...) Não sei onde vamos parar em termos de inviabilização do próprio Supremo Tribunal Federal.”

De fato, pode-se verificar um aumento no número de reclamações julgadas pelo Supremo nos últimos anos, principalmente na última década, quando começou a ser utilizada em alguns julgados do STF a teoria da transcendência dos motivos determinantes. Vale conferir uma tabela trazida pelo Min. Gilmar Mendes em seu voto na Reclamação 3014 ${ }^{85}$ :

\begin{tabular}{|l|c|l|c|}
\hline Ano & Número de reclamações & Ano & Número de reclamações \\
\hline 1990 & 20 & 1999 & 200 \\
\hline 1991 & 30 & 2000 & 522 \\
\hline 1992 & 44 & 2001 & 228 \\
\hline 1993 & 36 & 2002 & 202 \\
\hline 1994 & 45 & 2003 & 275 \\
\hline 1995 & 49 & 2004 & 491 \\
\hline 1996 & 49 & 2005 & 933 \\
\hline 1997 & 62 & 2006 & 837 \\
\hline 1998 & 275 & 2007 & $6^{*}$ \\
\hline
\end{tabular}

*Atualizada até 31.01.07.

Fonte: BNDPJ/STF.

Entretanto, apesar de válida a preocupação acerca do grande número de Reclamações que seriam ajuizadas perante o STF com a adoção da teoria, este não pode ser considerado um argumento fundamental para a rejeição da teoria.

De fato, a atribuição de caráter vinculante aos fundamentos determinantes das decisões do STF serviria para que os demais juízes e também os órgãos da Administração Pública atuassem de acordo com o precedente. Da mesma forma que haveria decisões contrárias ao precedente, 
ensejadoras de Reclamações, não se pode assumir que todos os juízes do País resolveriam - sadicamente - contrariar os precedentes vinculantes do STF apenas para que a questão fosse levada em sede reclamatória à Corte Suprema. Pelo contrário, a maior abrangência do efeito vinculante serviria de estímulo à adoção da teoria prevalecente no Supremo pelos demais órgãos do Judiciário. Até mesmo porque, caso desrespeitassem o posicionamento do STF, sua decisão seria passível de cassação.

Além disso, não se pode esquecer que o Direito Processual Constitucional, nos últimos anos, tem se mostrado pragmático ao lidar com a questão da multiplicidade de processos e recursos encaminhados às Cortes Superiores do País. Um exemplo disso, já ressaltado, foi a previsão da repercussão geral (CRFB/88, art. 102, § $3^{\circ}$ e Lei 11.418/06) para a admissão de Recursos Extraordinários. Outros exemplos são os mecanismos de julgamento em massa de processos que sejam atinentes à mesma questão, como o julgamento de recursos representativos de controvérsia (CPC, art. 543-B, $\S 1^{\circ}$ ) e a súmula vinculante (Lei 11.417/2006).

Especificamente em relação à Reclamação, é importante citar a previsão regimental de que o relator da Reclamação pode julgá-la monocraticamente, quando se tratar de jurisprudência consolidada do STF (Regimento Interno do STF, art. 161, parágrafo único).

Por fim, deve-se ressaltar que o questionamento da viabilidade do STF com a atribuição de efeito vinculante aos fundamentos de suas decisões em controle concentrado de constitucionalidade é o mesmo que pode ser levantado com a previsão da súmula vinculante, uma vez que o descumprimento desta também acarreta o cabimento de Reclamação.

Dessa forma, o argumento da inviabilidade do STF “deve ser muito bem ponderado, porque (...) a rejeição da eficácia transcendente frustra o estabelecimento de um sistema eficaz de precedentes vinculantes em sede de controle concentrado"

86 MELLO, Patrícia Perrone Campos. Op. cit., p. 165. 
Por sua vez, a doutrina ${ }^{87}$ tem ressaltado a desnecessidade da utilização da teoria, por causa da existência de outros instrumentos mais eficazes. André Dias Fernandes entende que para que o efeito vinculante incida sobre o holding da decisão, isto é, sobre a norma emergente do precedente em análise, não é preciso afirmar que o efeito vinculante alcança os motivos determinantes da questão.

$\mathrm{O}$ autor defende que o efeito vinculante incide sobre a norma que pode ser extraída do julgado. Porém, para o eminente jurista, essa norma é obtida somente pela análise do dispositivo da decisão, sendo "a análise das razões de decidir útil e recomendável para a perfeita intelecção da parte dispositiva do acórdão "88. Isso afastaria a necessidade de vinculação da fundamentação.

Tal crítica, entretanto, afigura-se como uma mera questão de nomenclatura. A análise dos motivos determinantes é essencial (não somente recomendável) para que se conheça o holding da decisão e, assim, delimite-se precisamente a extensão do efeito vinculante.

Inclusive é isso o que afirma a doutrina que defende a aplicação da teoria da transcendência dos motivos determinantes, a exemplo de Patrícia Perrone Campos de Mello, que chega a criticar o nomen jures desta teoria:

"Nota-se, portanto, que o que se vem defendendo, sob o rótulo de
"eficácia transcendente dos motivos determinantes", é, em verdade, a
extração de um "holding", equivalente à exegese constitucional fixada
pela Corte, a partir dos fundamentos da decisão produzida em sede
concentrada, e a conferência ao mesmo de eficácia normativa. Por isso, a
nomenclatura não é muito feliz. Ela gera uma impressão de que se
pretende conferir tais efeitos, de forma ampla, a toda a fundamentação, o
que não procede." 89

Na verdade, a vinculação nunca recai sobre toda a fundamentação, mas apenas sobre os motivos determinantes da decisão. O que se defende quando se adota a teoria é que para que se descubra qual é o holding da decisão é necessária a análise em conjunto da sua fundamentação

87 FERNANDES, André Dias. Eficácia das decisões do STF em ADIN e ADC. Efeito vinculante, coisa julgada erga omnes e eficácia erga omnes. Salvador: Jus Podivm, 2009, pp. 210-213.

88 FERNANDES, André Dias. Op. cit., p. 212 (grifos nossos).

89 MELLO, Patrícia Perrone Campos. Op. cit., pp. 156-157. 
determinante e do seu dispositivo. Não se poderia extrair uma norma geral capaz de ser aplicada a outros casos semelhantes apenas olhando para o dispositivo. Ainda mais nas decisões de controle concentrado de constitucionalidade, em que, normalmente, discute-se a constitucionalidade de apenas um diploma normativo, ou de alguns de seus dispositivos.

Imprescindível, dessa forma, a observância dos motivos determinantes da decisão para que se definam os limites do precedente vinculante, quer se entenda que os motivos determinante têm também efeito vinculante, quer se entenda que não.

Entretanto, apesar de alguns problemas serem de fácil sobreposição (como questões de simples nomenclatura), há alguns aspectos formais dos processos constitucionais que precisariam ser modificados antes da adoção plena da teoria da transcendência dos motivos determinantes no Direito brasileiro. Passamos agora a tratar de alguns desses problemas específicos e a apontar possíveis soluções.

\subsection{Contagem de votos não leva em conta os fundamentos da decisão:}

Como se sabe, os Tribunais brasileiros não têm o costume de contar votos em relação aos fundamentos das decisões. As decisões em órgãos colegiados se dão somente pela contagem dos votos em relação ao dispositivos.

Isso gera uma dificuldade prática para o implemento da teoria da transcendência dos motivos determinantes, uma vez que o texto constante da ementa de um acórdão reflete apenas o que decidiu o Tribunal por maioria ou por unanimidade de votos, considerando-se somente o dispositivo dos votos de seus membros.

Assim, o leitor do acórdão não consegue saber pela simples leitura da ementa e do dispositivo quais foram os fundamentos que levaram os Ministros do Supremo Tribunal Federal a seguir determinado entendimento.

$\mathrm{Na}$ verdade, seria teoricamente possível que uma decisão plenária 
unânime do STF fosse tomada com base em onze fundamentos distintos. Tome-se por exemplo uma lei estadual contestada em face da Constituição Federal em sede de ADIn. O Plenário do STF poderia declarar a inconstitucionalidade desta lei por unanimidade, sendo que cada Ministro a considerou inconstitucional por um motivo diferente do outro. Um dos Ministros pode abordar uma inconstitucionalidade formal, aduzindo que a lei estadual trata indevidamente de matéria federal. Este argumento pode nem ao menos ser citado por outro Ministro, que considera a tal lei estadual inconstitucional simplesmente por agredir o princípio da segurança jurídica. Ainda, outro Ministro poderia afirmar categoricamente que a lei estadual está condizente com o princípio da segurança jurídica e trata de matéria reservada pela Constituição Federal aos Estados, entretanto seria inconstitucional por violar o princípio da proporcionalidade.

De acordo com a prática judiciária do País, este acórdão hipotético traria em sua ementa a decisão unânime do Plenário pela inconstitucionalidade da lei estadual e simplesmente abordaria a posição do relator quantos ao fundamentos da decisão. Para que o leitor soubesse quais foram os fundamentos determinantes desta decisão do Plenário do STF teria que ler o inteiro teor do acórdão analisando voto por voto.

Isso, de fato, inviabiliza que se saiba quais são os fundamentos da decisão do STF, tornando complicada a extensão do efeito vinculante aos fundamentos.

Primeiro, porque nem sempre haverá uma única fundamentação determinante para a decisão. Um fundamento poderia ser considerado determinante quando a maioria dos Ministros que votaram em determinado sentido trouxeram este mesmo fundamento como motivo suficiente para decidir daquela forma. Então, por exemplo, numa decisão de procedência em uma ADIn por oito votos a três, somente se cinco daqueles oito Ministros que votaram pela procedência abordassem o mesmo fundamento este seria considerado como motivo determinante a integrar o holding da decisão dotado de efeito vinculante. 
Não é plausível exigir dos demais cidadãos que analisem o inteiro teor do acórdão para sistematizar a decisão de cada um e seus fundamentos e, assim, descobrir se houve ou não motivos determinantes capazes de integrar o holding daquele julgado.

Desa forma, para que se admita a plena aplicação da teoria da transcendência dos motivos determinantes no ordenamento brasileiro, é importante haver uma Emenda Regimental ao Regimento Interno do STF de forma a tornar obrigatória a contagem dos votos em relação aos fundamentos.

Porém, a simples contagem não seria suficiente se o texto com os fundamentos determinantes não fosse publicado juntamente com o dispositivo do acórdão. A desnecessidade de publicação dos fundamentos da decisão ainda é uma das críticas mais consistentes em relação à aplicação da teoria da transcendência dos motivos determinantes. Sobre o assunto, destaca André Dias Fernandes:

"É que nos arts. 28, caput, e 21, parágrafo único, a Lei no 9.86899, confirmando a praxe do STF, só determina a publicação oficial da parte dispositiva dos acórdãos do STF em ADIn e ADC que produzem efeito vinculante, ou seja, tão somente a parte dispositiva das decisões concessivas de cautelar em ADIn e ADC e das decisões definitivas de mérito em ADIn e ADC é que precisam ser publicadas oficialmente.

Ora, é princípio universalmente consagrado o de que as leis só passam a vigorar após sua publicação oficial, pois só a partir de então é que se passa a conhecer seu texto oficial que vinculará a todos os seus destinatários. Sem o conhecimento do texto oficial, não há como obrigar ninguém a cumpri-lo. Afinal, como se pode obedecer a uma ordem se não se sabe o teor desta ordem? Assim, mesmo a ficção legal segundo a qual se considera a lei como conhecida de todos não prescinde da publicação oficial da lei, a partir da qual esta ficção pode começar a operar.",90

De fato, afigura-se necessária não só a contagem de votos em relação à fundamentação, mas também a publicação deste resultado, juntamente com a contagem dos votos em relação aos dispositivos.

A solução para isso seria uma alteração legal que passasse a prever a publicação dos fundamentos determinantes da decisão. Porém, mesmo sem tal alteração, não seria impossível a adoção da teoria da transcendência, 
uma vez que o próprio STF poderia colocar no texto a ser publicado o resultado da contagem de votos da fundamentação. Não haveria necessidade da publicação do inteiro teor dos acórdãos e de todos os votos. Até mesmo na ementa do acórdão poderia constar a fundamentação que levou o STF a decidir daquela forma. Seriam expostos os resultados da votação dos Ministros quanto aos fundamentos e quanto ao dispositivo.

\subsection{Grande extensão dos votos dos Ministros do STF:}

Poder-se-ia sugerir que de fato fosse feita a leitura do inteiro teor do acórdão para se descobrir os fundamentos da decisão do Supremo. Porém, isso se mostraria absolutamente inviável, tendo em vista o elevado nível de prolixidade dos votos dos Ministros.

De fato, os Ministros do STF não costumam ser sucintos em seus pronunciamentos. Na verdade, uma simples pesquisa no site do STF na internet leva à descoberta de que não são raros os acórdãos com 10 páginas ou mais por voto de cada Ministro. Isso dá uma média de mais de 110 páginas por decisão do Supremo. Além disso, em “casos especiais”, como o caso da reserva Raposa do $\mathrm{Sol}^{11}$, ou o caso da pesquisa com célulastronco $^{92}$, muitos Ministros estenderam seus votos singulares por cerca de 100 páginas.

Levando em consideração que há milhares de processos tramitando no STF e que diversos deles são decididos todos os dias, é impossível na prática que alguém conheça de forma completa a jurisprudência da Corte Suprema.

Até mesmo para que se efetuasse a contagem dos votos em relação aos motivos determinantes isso seria um grande fator impeditivo. A leitura e sistematização das razões de decidir de cada um dos Ministros e a comparação de um voto com os outros seria extremamente prejudicada pela grande extensão da redação desses votos. 
Para resolver essa situação não seria extremo propor que haja, também por alteração regimental, a imposição de limite de páginas aos votos. Excetuando o relatório do caso, feito somente pelo relator da causa, dez páginas é um espaço mais do que razoável para que um Ministro exponha seu posicionamento e os motivos que o levaram a decidir de tal forma.

Isso não significa que os Ministros ficariam rigidamente limitados a este número de páginas, que, logicamente, poderia ser ultrapassado de forma razoável em situações especiais.

Os Ministros do Supremo, ainda, poderiam expor seus longos pronunciamentos em um campo específico na página virtual do Tribunal na internet, de forma a dar acesso aos cidadãos às suas decisões completas, que, apesar de muito prolixas, trazem grandes lições de Direito e são muito proveitosas a quem tem o tempo e o interesse de lê-las.

Por fim, a grande extensão dos votos dos Ministros em suas decisões poderia ferir até mesmo o princípio da publicidade (CF, art. 37, caput), uma vez que as decisões publicadas, ainda que contivessem os motivos determinantes, não seriam de fácil acesso ou compreensão.

Portanto, para que os fundamentos da decisão sejam também vinculantes, eles devem ter o mesmo tratamento que o dispositivo da decisão. A publicação da decisão deve conter a síntese do decidido pelo Tribunal por maioria de votos ou por unanimidade, incluindo os fundamentos determinantes que levaram a tal decisão, se houver fundamentos majoritários, adotados pela maioria ou por todos os Ministros em sua decisão. 


\section{Instrumento adequado para a implantação da teoria - a Reclamação Constitucional:}

Como já mencionado, a Reclamação é um instrumento para a impugnação de decisões com previsão expressa na Constituição Federal:

"Art. 102. Compete ao Supremo Tribunal Federal, precipuamente, a guarda da Constituição, cabendo-lhe:

$\boldsymbol{I}$ - processar e julgar, originariamente:

(...)

l) a reclamação para a preservação de sua competência e garantia da autoridade de suas decisões".

Primeiramente, a Reclamação adentrou o campo do Direito Brasileiro $^{93}$ como uma construção pretoriana, com a aprovação de uma emenda ao Regimento Interno do STF, em 02.10.1957. A Constituição de 1967 nada falou sobre a Reclamação, mas remeteu ao Regimento Interno do STF o tratamento da matéria. Somente a Constituição de 1988 trouxe em seu texto a previsão da via reclamatória, nos termos acima expostos.

Atualmente, o tratamento legal da Reclamação é feito pela Lei 8.038/1990 em seus arts. 13 a 18 e seu procedimento é definido pelo Regimento Interno do STF, arts. 156 a 162 e pelo Regimento Interno do STJ, arts. 187 a 192. Entretanto, como não há uma norma legal específica que trate exaustivamente da Reclamação, muitos de seus contornos foram trazidos pela própria jurisprudência, principalmente a do STF.

Tal possibilidade também é trazida pela doutrina. Sobre a Reclamação, afirma José Frederico Marques: "Inserindo-se, assim, no campo do Direito Processual Constitucional, pode a ordem jurídica, mediante normas regimentais, criar providências dessa natureza para a garantia de observância de julgados em que interfere, até mesmo, o

93 A doutrina chega a afirmar que, tendo em vista as peculiaridades da Reclamação, não há no direito estrangeiro qualquer previsão que se possa comparar à Reclamação. Nesse sentido, GÓES, Gisele Santos Fernandes. A Reclamação Constitucional. In: NERY JR., Nelson, WAMBIER, Teresa Arruda Alvim (coordenadores). Aspectos polêmicos e atuais dos recursos cíveis e de outros meios de impugnação às decisões judiciais. São Paulo: Revista dos Tribunais, 2005, p. 128. 
guardião supremo e último da própria Lei Magna”, 94

A evolução e o desenvolvimento jurisprudencial do instituto podem ser verificados em diversos momentos. Por exemplo, na Reclamação 5389$\mathrm{PA}^{95}$, o STF decidiu que só as decisões proferidas em sede de controle abstrato de constitucionalidade podem ser utilizadas como parâmetro de Reclamação, uma vez que só elas são dotadas de efeito vinculante. No caso, a Reclamação fora proposta pelo descumprimento dos motivos determinantes da decisão proferida em outra Reclamação. Tal hipótese, obviamente, não se insere no campo de atuação da Reclamação e nem seria admitida pelos que defendem a aplicação da teoria da transcendência dos motivos determinantes.

Outro exemplo do contorno jurisprudencial dado à Reclamação é o reconhecimento da possibilidade de qualquer interessado se recorrer da via reclamatória, além do próprio Ministério Público, por previsão legal (Lei 8.038/90, art. 16). Isso foi afirmado pelo STF quando do julgamento do Agravo Regimental na Reclamação $1880^{96}$, em 23.05.2002. Dessa forma, qualquer um que comprove prejuízo efetivo advindo da desobediência às decisões do STF pode se utilizar da Reclamação para obter a tutela jurisdicional devida, como forma de garantir máxima efetividade ao efeito vinculante e à eficácia erga omnes das decisões proferidas em sede de controle concentrado de constitucionalidade pelo Supremo.

É possível perceber, ainda, um grande avanço do uso da Reclamação no País. Além da previsão constitucional da Reclamação para a preservação dos julgados do Superior Tribunal de Justiça, como guardião da legislação federal infraconstitucional, até mesmo alguns Estados têm trazido, em suas Constituições, um instituto assemelhado à Reclamação (com a mesma

\footnotetext{
94 MARQUES, José Frederico. Instituições de Direito Processual Civil, vol. IV, $2^{\mathrm{a}}$ edição, Forense, p. 315, 316.

95 STF, Rcl 5389-PA, Rel. Min. Cármen Lúcia, Brasília, 20.11.2007.

96 STF, Rcl 1880-SP, AgRg, Rel. Min. Maurício Corrêa, 07.11.02.
} 
nomenclatura, inclusive), para resguardo das decisões dos Tribunais de Justiça.

Esta inovação do Direito Constitucional Estadual foi vista com bons olhos pelo Supremo, que afirmou a constitucionalidade desta possibilidade na ADIn 2212-CE ${ }^{97}$. No julgamento, a Ministra Ellen Gracie ressaltou em seu voto:

"Não vejo porque não se possa, no âmbito estadual, em nome do princípio da simetria, dotar os Tribunais de Justiça desse instrumento, para garantir a autoridade das suas decisões que, não impugnadas pela via recursal, tenham ali mesmo transitado em julgado. Ou então para preservar a sua competência, eventualmente invadida por ato de outro Juízo ou Tribunal local.”

Com esse entendimento, o STF julgou improcedente a ADIn 2212 que buscava a declaração de inconstitucionalidade do art. 108, VII, "i" da Constituição do Estado do Ceará, dispositivo que dava ao Tribunal de Justiça do Estado a competência para julgar um instrumento semelhante à Reclamação, para a preservação de sua competência e da autoridade de suas decisões $^{98}$.

Quanto à natureza jurídica da Reclamação Constitucional, há atualmente grande debate doutrinário. Sua nomenclatura não ajuda, pois a expressão reclamação é utilizada tanto para se referir a este remédio constitucional quanto para se referir ao instituto da reclamação correicional, antigo instrumento administrativo destinado à investigação de atuações inadequadas dos juízes, que poderia ser instaurado, inclusive, $e x$ officio. De acordo com a clássica definição de Alfredo Buzaid, a reclamação correicional é:

"Reclamação de ordem administrativa tendente a emendar erros e abusos acarretadores de inversão tumultuária de atos e fórmulas processuais, aberta aos interessados na causa ao Procurador-Geral [de Justiça], diante da existência, num feito judiciário qualquer, de abusos praticados pelo juiz; inversão tumultuária do procedimento; e ausência de recurso específico para corrigir tal situação." 99

97 STF, ADIn 2212-CE, Rel. Min.Ellen Gracie, Brasília, 02.10.2003.

98 A Reclamação era prevista no Regimento Interno do TJCE, art. 21, VI, “j”.

99 BUZAID, Alfredo. Correição parcial - recursos processuais - reresentação. Revista Forense, $\mathrm{n}^{\mathrm{o}}$ 175, pp. 90-96. Rio de Janeiro: Forense, 1958. 
De fato, na vigência do antigo Código de Processo Civil de 1939, tal instituto era muito utilizado, pois o agravo de instrumento era um recurso que servia para impugnar apenas algumas decisões interlocutórias. Como diversas decisões interlocutórias não eram impugnáveis, utilizava-se a reclamação correicional (ou correição parcial) para atacá-las.

Porém, com o advento do CPC de 1973, o agravo de instrumento e o agravo retido passaram a ser os meios adequados de impugnação de todas as decisões interlocutórias, não sobrando espaço para a reclamação correicional.

"Diante disso, restou esvaziada a reclamação correicional ou a correição parcial, não devendo ser utilizada como meio de impugnação de decisões judiciais, por haver recurso com tal finalidade. E isso porque um mecanismo administrativo, em razão do princípio da separação dos poderes, não deve conter aptidão para atacar um ato judicial."100

Dessa forma, é patente que a Reclamação Constitucional e a reclamação correicional não se confundem, primordialmente, por ter a primeira caráter estritamente judicial, posto que visa a cassação de uma decisão judicial, e a segunda caráter meramente administrativo.

Apesar de ser pacífico na doutrina ${ }^{101}$ o entendimento de que a Reclamação Constitucional nada tem a ver com a reclamação correicional, o debate doutrinário prossegue para se saber qual é a verdadeira natureza jurídica do instituto em comento.

Nelson Nery Jr. ${ }^{102}$ entende que a Reclamação Constitucional tem natureza jurídica de incidente processual. Porém, este não parece ser o melhor entendimento, porque o incidente processual tem determinadas características não encontradas na Reclamação. Na precisa lição de Leonardo José Carneiro da Cunha:

"Muito embora não haja uma noção precisa e bem delimitada do que seja incidente processual, é possível estabelecer os seus pressupostos, quais

100 CUNHA, Leonardo José Carneiro da. Natureza Jurídica da Reclamação Constitucional. In: NERY JR., Nelson, WAMBIER, Teresa Arruda Alvim (coordenadores). Aspectos polêmicos e atuais dos recursos cíveis e de outros meios de impugnação às decisões judiciais. São Paulo: Revista dos Tribunais, 2005, p. 328.

101 GÓES, Gisele Santos Fernandes. Op. cit., p. 125.

102 NERY JUNIOR, Nelson. Princípios fundamentais: teoria geral dos recursos. $3^{\mathrm{a}}$ ed. São Paulo: Revista dos Tribunais, 1996. p. 77. 
sejam (a) uma situação nova que cai (b) sobre algo que preexiste. $\mathrm{O}$ incidente somente existe, se houver, antes, um processo judicial em curso. Surgindo um incidente processual, altera-se o curso do procedimento, podendo haver seu encerramento prematuro, com a extinção do processo, ou um retardamento, com um desvio de rota: o procedimento se suspende ou se altera em razão do incidente. A reclamação constitucional não preenche tais requisitos, não se enquadrando, portanto, como um incidente processual." 103

Outra parte da doutrina ${ }^{104}$ afirma que a Reclamação tem natureza jurídica de sucedâneo recursal. Entretanto, essa também não parece ser a melhor posição, porque os sucedâneos recursais buscam obter a reforma ou a anulação de uma decisão judicial, enquanto o objetivo da Reclamação é a cassação da decisão contrária à decisão do STF. A decisão da Reclamação nunca substituirá a decisão reclamada, tampouco a anulará, de forma a exigir que seu órgão prolator emita novo pronunciamento.

Pelos mesmos motivos, não seria possível afirmar que a Reclamação tem natureza jurídica de recurso ${ }^{105}$. Os recursos também visam obter a reforma da sentença recorrida ou a sua anulação.

Além disso, os recursos seguem o princípio da taxatividade, segundo o qual para que haja um recurso deve haver um diploma normativo que o preveja. Realmente, a Reclamação não está prevista nem no CPC, art. 496 nem em nenhuma outra lei como um recurso processual, de forma que não pode ser considerado como tal.

Por fim, a própria Constituição Federal colocou a Reclamação como uma das hipóteses de competência originária do STF e do STJ, não de sua competência recursal.

Ainda, outra parte da doutrina, encabeçada por Cândido Dinamarco e Humberto Theodoro Júnior ${ }^{106}$, indica que a natureza jurídica da Reclamação é de remédio processual diverso do recurso. Cândido Dinamarco afirma que

\footnotetext{
103 CUNHA, Leonardo José Carneiro da. Op. cit., p. 332-333.

104 MARQUES, José Frederico. Manual de direito processual civil, volume 3. Atualizado por Vanilson Rodrigues Alves. Campinas: Bookseller, 1997, p. 230; LIMA, Alcides de Mendonça. O Poder Judiciário e a nova Constituição. Rio de Janeiro: Aide, 1989, p. 80.

105 CUNHA, Leonardo José Carneiro da. Op. cit., p. 330.

106 JUNIOR, Humberto Theodoro. Curso de direito processual civil, vol. 1. 18 a edição. Rio de Janeiro: Forense, 1996, p. 604-605.
} 
a expressão "Reclamação Constitucional" "é muito ampla e abriga em si todas as medidas mediante as quais, de algum modo, se afasta a eficácia de um ato judicial viciado, se retifica o ato ou se produz sua adequação aos requisitos da conveniência ou da justiça (Carnelutti) "107.

Porém, essa tese sofre críticas doutrinárias ${ }^{108}$, pois afirmar que a Reclamação é simplesmente um remédio constitucional não significa dizer muito. A expressão se mostra muito abrangente, não servindo para uma boa definição da Reclamação Constitucional.

Outra parte da doutrina ${ }^{109}$ defende a natureza jurídica de ação para a Reclamação. Seria uma ação, por causa de suas características definidoras, uma vez que, segundo esses autores, apresenta também os elementos essenciais da ação. Como afirma Leonardo José Carneiro da Cunha:

\begin{abstract}
"A reclamação constitucional consiste, a bem da verdade, numa ação, ajuizada originariamente no Tribunal Superior, com vistas a obter a preservação de sua competência ou a garantir a autoridade de seus julgados. A reclamação contém, inclusive, os elementos da ação, a saber: partes, causa de pedir e pedido. Realmente, há o reclamante e o reclamado, contendo a formulação de um pedido e a demonstração de uma causa de pedir, consistente na invasão de competência ou na desobediência à decisão da corte."
\end{abstract}

Dessa forma, os que veem na Reclamação uma ação constitucional defendem que, sendo uma ação, a Reclamação seria de competência legislativa privativa da União (CF, art. 22, I), impossível sua previsão em âmbito estadual, a não ser por lei federal. A decisão da Reclamação está sujeita aos efeitos da coisa julgada, como qualquer outra ação. Além disso, para a sua propositura há a exigência de capacidade postulatória, devendo o reclamante ser representado por advogado devidamente constituído.

Contrariamente a essa tese, posiciona-se Ada Pelegrini Grinover, que afirma ser a natureza jurídica da Reclamação uma manifestação do direito

107 DINAMARCO, Cândido Rangel. A reclamação no processo civil brasileiro. In: NERY JR., Nelson, WAMBIER, Teresa Arruda Alvim (coordenadores). Aspectos polêmicos e atuais dos recursos cíveis e de outros meios de impugnação às decisões judiciais, volume 6. São Paulo: Revista dos Tribunais, 2002, p. 100.

108 GÓES, Gisele Santos Fernandes. Op. cit., p. 130.

109 Ibid. p. 130.

110 CUNHA, Leonardo José Carneiro da. Op. cit., p. 333. 
constitucional de petição, assegurado pelo art. 5, XXXIV, “a”, CRFB/88. Nas palavras da autora: "não se trata de ação, uma vez que não se vai discutir a causa com um terceiro; não se trata de recurso, pois a relação processual já está encerrada, nem se pretende reformar a decisão, mas antes garanti-la. Cuida-se simplesmente de postular perante o próprio órgão que proferiu uma decisão o seu exato e integral cumprimento. "111

Esse foi o entendimento adotado pelo Supremo Tribunal Federal no julgamento da ADIn 2.212-1-CE ${ }^{112}$, em que se decidiu que os Estados poderiam prever o instituto da Reclamação no âmbito dos Tribunais de Justiça Estaduais, justamente porque o instituto ostenta a natureza jurídica de direito de petição, o que o retirava do âmbito legislativo do direito processual, que é de competência legislativa privativa da União (CRFB/88, art. 22, I).

Entretanto, a posição adotada pelo STF sofre algumas críticas doutrinárias. Leonardo José Carneiro da Cunha ${ }^{113}$ afirma que a Reclamação tem caráter jurisdicional, enquanto o direito de petição tem caráter administrativo, de forma que seria incompatível sustentar que, sendo uma decorrência do direito de petição, a decisão da Reclamação se submeteria à coisa julgada.

Também sustenta o douto jurista ${ }^{114}$ que o entendimento do STF seria contraditório, pois, ao mesmo tempo que caracteriza a Reclamação como um direito de petição, estabelece a necessidade de previsão constitucional para que este instrumento possa ser adotado. Cada Estado deveria trazer em sua Constituição Estadual a previsão do instituto. Porém, tal previsão não seria possível no que concerne aos Tribunais Regionais Federais, uma vez que sua competência é tratada na Constituição Federal, que nada dispõe sobre a Reclamação em seu âmbito.

Além disso, como o direito de petição é previsto na Constituição

111 GRINOVER, Ada Pelegrini. “A reclamação para a garantia da autoridade das decisões dos Tribunais”, Revista Jurídica Consulex, ano VI, n 127, 30.04.2002, p.39-42.

112 STF, ADIn 2212-1-CE, Rel. Min. Ellen Gracie, 02.10.03.

113 CUNHA, Leonardo José Carneiro da. Op. cit., p. 338.

114 Ibid. p. 339. 
Federal como voltado a todos os órgãos do Poder Público, Leonardo Cunha afirma que seria contraditório afirmar a necessidade de previsão constitucional específica da Reclamação para cada Tribunal. Nas palavras do autor:

"Tendo o STF firmado o entendimento segundo o qual a reclamação constitui uma simples manifestação do direito de petição, pode-se concluir, então, que pode ser ajuizada em qualquer tribunal ou órgão do Poder Judiciário. Não seria necessário, aliás, que uma Constituição Estadual previsse a reclamação constitucional, sendo igualmente possível de ser intentada num Tribunal Regional Federal. É que o direito constitucional de petição é autoexecutável, estando previsto na Constituição Federal para todos os órgãos do Poder Público.

O STF, contudo, entendeu que somente pode haver reclamação para os Tribunais Estaduais, além das hipóteses estabelecidas para os Tribunais Superiores, desde que a respectiva Constituição Estadual a preveja expressamente, vindo a ser sua previsão secundada por cada regimento interno. No entender do STF, não se viabiliza a reclamação para os Tribunais Regionais Federais.

Tal entendimento, com o devido respeito, é contraditório.

Ora, o direito de petição é autoaplicável, previsto na Constituição Federal para todos os órgãos do Poder Público. Revestindo-se da natureza de direito de petição, a reclamação podeira ser intentada junto a Tribunal Regional Federal ou a Tribunal de Justiça, independentemente de previsão em Constituição Estadual ou regimento interno. É que o direito de petição constitui uma garantia individual do ciadão, já estando outorgada pela Carta Magna Federal, independentemente de regulamentação ou previsão em qualquer outro diploma normativo."

Apesar de todo este debate doutrinário acerca da natureza jurídica da Reclamação Constitucional, o STF adotou a posição segundo a qual a Reclamação seria uma manifestação do direito de petição, previsto na Constituição Federal, art. 5, XXXIV, “a”, rechaçadas as demais teorias que vislumbravam na Reclamação uma ação, um incidente processual, um remédio constitucional indefinido, um recurso ou um sucedâneo recursal.

De qualquer sorte, a Reclamação continua sendo o instrumento apropriado para a aplicação da teoria da transcendência dos motivos determinantes, independente da definição de sua natureza jurídica, uma vez que serve para levar ao Tribunal que proferiu uma decisão vinculante um caso em que esta não foi obedecida, dando-lhe a oportunidade de cassar a referida decisão afrontadora de sua jurisprudência. 
O objetivo da Reclamação é conferir aos jurisdicionados um meio hábil e célere para fazer valer o que foi decidido pelo Poder Público no exercício de sua função jurisdicional. Em outras palavras, a Reclamação serve para levar ao órgão que proferiu determinada decisão um caso em que esta foi desrespeitada, quando deveria ter sido obedecida, para que este mesmo órgão judicial ordene o integral e exato cumprimento de sua decisão. Serve também para garantir a competência do Tribunal, podendo ser tomada qualquer medida adequada a se fazer cumprir a competência afrontada.

A Reclamação, nesse sentido, foi concebida como uma rota de fuga, um atalho ao longo caminho de recursos que o jurisdicionado prejudicado teria que enfrentar para conseguir usufruir de seus direitos. Quando a parte já conta com uma decisão favorável e vinculante aos outros órgãos jurisdicionais e administrativos, o caminho natural de um processo ordinário somente faria prolongar um estado de injustiça por ele experimentado.

Analisando seus aspectos formais, a doutrina ${ }^{116}$ afirma que a Reclamação tem natureza mandamental, já que busca o cumprimento de uma decisão judicial por uma autoridade.

Além disso, nem a Constituição Federal nem a legislação infraconstitucional estabelecem prazos para o exercício do direito de ajuizamento da Reclamação. Entretanto, o STF afirma, em entendimento sumulado $^{117}$, que não cabe Reclamação de ato judicial transitado em julgado. Dessa forma, é possível dizer que o prazo para a propositura da Reclamação se estende até o trânsito em julgado da decisão que se pretende cassar.

Se a Reclamação for decidida pelo relator, nos termos do Regimento Interno do STF, a decisão poderá ser atacada por meio de agravo

116 FUX, Luiz. Curso de direito processual civil. Rio de Janeiro: Forense, 2001. p. 958; GÓES, Gisele Santos Fernandes. Op. cit., p. 133.

117 Enunciado 734 da súmula da jurisprudência dominante no STF: "não cabe reclamação quando já houver transitado em julgado o ato judicial que se alega tenha desrespeitado decisão do supremo tribunal federal." 
regimental, de acordo com o que determina o art. 317 do referido diploma regimental.

A doutrina ${ }^{118}$ traz algumas hipóteses de cabimento interessantes da Reclamação. Uma delas é a negativa de seguimento ao agravo de instrumento que negou inadmitiu o recuso extraordinário ou o recurso especial. Isso porque o presidente do tribunal de origem tem a prerrogativa de negar seguimento a tais recursos, na forma do CPC, art. 541. Contra tal decisão, cabe agravo de instrumento que também é submetido à presidência do tribunal a quo, de acordo com o CPC, art. 544, $\S 2^{\circ}$. Porém, dessa vez, o presidente do tribunal não pode negar o agravo, uma vez que lhe falta amparo legal para tanto. Se houver tal negativa ao agravo de instrumento, isso será uma hipótese de invasão de competência a ensejar o uso da via reclamatória. Isso pode ser extraído tanto da jurisprudência do $\mathrm{STF}^{119}$ quanto da doutrina $^{120}$.

Outra hipótese, trazida pela doutrina ${ }^{121}$, seria a tentativa perpetrada pelo tribunal a quo de atingir a competência dos Tribunais Superiores através da prática ou da omissão de um ato, ou ainda de seu retardamento. $\mathrm{O}$ autor também ressalta que a jurisprudência ${ }^{122}$ vem acolhendo a demora do juízo na execução de um julgado como sendo outra hipótese ensejadora da Reclamação.

A jurisprudência também tem acolhido Reclamação contra atos administrativos ${ }^{123}$ e contra atos que descumpram medidas liminares dotadas de efeito vinculante ${ }^{124}$.

118 MORATO, Leonardo Lins. A reclamação prevista na Constituição Federal. In: ARRUDA ALVIM, Eduardo Pelegrini de; NERY JUNIOR, Nelson; WAMBIER, Teresa Arruda Alvim (Coord.). Aspectos polêmicos dos recursos. São Paulo: Revista dos Tribunais, 2000, p. 443.

119 STF, Rcl 510-1-SP; STJ, Rcl 517-RJ.

120 NERY JUNIOR, Nelson; NERY, Roda Maria de Andrade. CPC comentado. $5^{\text {a }}$ ed. São Pulo: Revista dos Tribunais, 2001, p. 1.057.

121 MORATO, Leonardo Lins. A reclamação prevista na Constituição Federal. In: ARRUDA ALVIM, Eduardo Pelegrini de; NERY JUNIOR, Nelson; WAMBIER, Teresa Arruda Alvim (Coord.). Aspectos polêmicos dos recursos. São Paulo: Revista dos Tribunais, 2000, p. 444.

122 STJ, Rcl 267-4-DF, rel. Min. César Rocha, 16.05.1995.

123 STJ, Rcl 283-DF, rel. Min. Américo Luiz, 25.05.1995; Rcl 326-DF, rel. Min. José Dantas, 07.04.1997.

124 STF, Rcl 1652, rel. Min. Gilmar Mendes, 28.04.03. 
Por fim, o $\mathrm{STF}^{125}$ afirma a impossibilidade do cabimento de Reclamação contra o decidido em outra Reclamação. Isso porque o descumprimento da decisão de uma Reclamação não deve ser atacado novamente pela via reclamatória, sob pena de surgir um ciclo vicioso, devendo a parte lesada se valer de outras medidas coativas. Além disso, a decisão da Reclamação não tem efeito vinculante.

Entretanto, a doutrina ${ }^{126}$ aborda uma situação em que isso poderia ser relativizado. No caso de o STJ julgar um Reclamação exorbitando de sua competência, invadindo o âmbito de atuação destinado ao STF, seria cabível Reclamação ao Supremo em virtude da decisão proferida pelo STJ.

Abordados, dessa forma, os aspectos formais da Reclamação, vemos que o instituto foi concebido pelo constituinte como o meio adequado a se proteger a autoridade das decisões dos Tribunais Superiores e garantir-lhes a competência. Assim, a Reclamação é vista como um importante instrumento do Direito Constitucional para resguardar a segurança jurídica. Nesse sentido, destaca Gisele Santos Fernandes Góes:

"Logo, o instituto da reclamação emerge como o instrumento de decisão
no ordenamento jurídico brasileiro, cuja finalidade é a absorção da
insegurança, não no sentido de eliminar o conflito, mas porque o
transforma, visto que as autoridades criarão sempre novas situaçães de
incompatibilidade - invasão de competência e/ou desobediência - e, por
essa rotatividade, a reclamação como proteção da Jurisdição
Constitucional (Supremo Tribunal Federal e Superior Tribunal de Justiça)
fomenta a alternativa de decidibilidade do conflito no sistema."

A mesma jurista afirma que a Reclamação também é um instrumento que visa a proteger o Estado Democrático de Direito e o princípio da proporcionalidade. Em suas palavras:

"Aduzimos somente que, mais do que os princípios do juiz natural e da
tutela jurisdicional adequada, deve-se compreender que os fundamentos
maiores para o instituto da reclamação a serem destacados são os do
Estado Democrático de Direito e da proporcionalidade, porque a
desobediência e a usurpação de competência, deparando-se com
jurisdição constitucional e uniformização da interpretação de lei federal,
constituem o rompimento da estrutura da organização judiciária 
brasileira, instalando-se a insegurança no seio da tutela jurisdicional." ${ }^{128}$

Com efeito, é possível afirmar que a Reclamação é o meio escolhido pela Constituição de 1988 para a proteção da ordem constitucional brasileira como um todo, uma vez que a Constituição não só determina que o STF seja o guardião da Constituição (art. 102, caput), como também afirma que a Reclamação é o instrumento que protege sua a competência e a autoridade de suas decisões.

Como ressaltado pelo Ministro do STF, Gilmar Mendes:

"A tendência hodierna é de que a reclamação assuma cada vez mais o papel de ação constitucional voltada à proteção da ordem constitucional como um todo. Os vários óbices à aceitação da reclamação em sede de controle concentrado de constitucionalidade, inclusive, já foram superados, estando o Supremo Tribunal Federal em condições de ampliar o uso desse importante e singular instrumento da jurisdição constitucional brasileira. A ordem constitucional necessita de proteção por mecanismos processuais céleres e eficazes.

A reclamação constitucional - sua própria evolução o demonstra - não mais se destina apenas a assegurar a competência e a autoridade de decisões específicas e bem delimitadas do Supremo Tribunal Federal, mas também constitui-se como ação voltada à proteção da ordem constitucional como um todo." ${ }^{\prime 29}$ (grifos nossos)

Assim, abre-se caminho para que o efeito vinculante das decisões do STF em controle concentrado de constitucionalidade seja plenamente observado por todos os demais órgãos do Poder Judiciário e os órgãos do Poder Executivo. A Reclamação aparece, portanto, como o instrumento necessário para a efetivação da vinculação dos precedentes do STF, vinculação esta trazida pela própria Constituição.

Para a correta utilização da Reclamação, tornou-se imperativo se definir os limites objetivos do efeito vinculante. É por esse motivo que a teoria da transcendência dos motivos determinantes começou a ser utilizada no bojo de Reclamações que eram levadas ao Supremo. Como tentativa de assegurar a ordem constitucional em sua totalidade e garantir as decisões do Supremo como orientadoras dessa ordem, na sua qualidade de guardião da Constituição Federal, foi importante a extensão do efeito vinculante aos

129 STF, Rcl 6189-MS, Rel. Min. Gilmar Mendes, Brasília, 23.09.2008. 
fundamentos das decisões, como forma de garantir diversos princípios constitucionais, como o da isonomia, da celeridade processual, da segurança jurídica etc.

É por isso que a Reclamação é o meio ideal para conferir maior efetividade aos precedentes do STF, principalmente àqueles com caráter vinculante, em que a Suprema Corte interpreta diretamente a Constituição Federal. Nesse sentido também se posiciona a doutrina: "a destinação constitucional da via reclamatória, portanto, além de vincular esse meio processual à preservação da competência global do Supremo Tribunal Federal, prende-se, também, ao objetivo específico de salvaguardar a extensão e os efeitos dos julgados da Suprema Corte ${ }^{\text {,130. }}$

Portanto, o instrumento da Reclamação, utilizado juntamente com a teoria da transcendência dos motivos determinantes, tornou mais eficaz a normatividade da Constituição Federal, ao permitir que eventuais afrontas às decisões vinculantes do STF ou à sua competência sejam rapidamente revistas pelo próprio Supremo, de forma a diminuir o estado de insegurança jurídica

$\mathrm{e}$ injustiça.

130 MARQUES, José Frederico. Instituições de Direito Processual Civil, vol. IV, $2^{\mathrm{a}}$ edição, Forense, p. 393. 


\section{A jurisprudência do STF sobre o tema:}

Como já dito anteriormente, a adoção da teoria da transcendência dos motivos determinantes é um assunto delicado na jurisprudência do STF, que não encontra uma resposta pacífica da Corte. Recentemente, todos os pronunciamentos do Supremo acerca da teoria têm sido no sentido de não acolhê-la ${ }^{131}$.

Porém, nem sempre foi assim. Durante alguns anos a questão foi levantada por alguns Ministros do STF e debatida em diversos acórdãos, às vezes sendo acolhida, às vezes sendo rejeitada.

Pode-se destacar a Reclamação $\mathbf{3 9 0}^{\mathbf{1 3 2}}$, do ano de 2001, como precursora do tema na jurisprudência do Supremo. O Procurador-Geral da República ajuizou reclamação contra ato do TJRS que promoveu, a cargo de Desembargador, um Juiz do então Tribunal de Alçada do mesmo Estado, em vaga reservada ao quinto constitucional. A reclamação alegou violação à decisão proferida na ADIn 29-RS, em que o STF decidiu que a vaga destinada ao quinto constitucional deveria ser preenchida nos exatos termos do art. 94 da CRFB/88. Em suas informações, o Presidente da Corte reclamada afirmou que o STF se limitou a declarar inconstitucional o parágrafo único do Assento ${ }^{\circ}$ 4/88, do TJPR, o qual ficou, pois, eliminado do rol de seus atos normativos. Porém, a decisão reclamada teria se baseado na exegese conferida do art. 93, III, CF, não havendo ofensa ao julgado. $\mathrm{O}$ Min. Néri da Silveira destacou em seu voto existir um confronto entre o ato objeto da reclamação e o conteúdo da decisão do STF na ADIn, daí decidindo pela procedência do pedido naquela hipótese. $\mathrm{O}$ ato impugnado estava em descompasso com o conteúdo dos acórdãos do STF sobre a questão.

Como se percebe, o STF se utilizou do conteúdo da decisão de uma ADIn para determinar que norma semelhante deveria ser considerada

131 STF, Rcl 3014 AgR, Rel. Min Ayres Britto, Brasília, 21.05.10; Rcl 5703 AgR, Rel. Min Cármem Lúcia, Brasília, 16.10.09; Rcl 8175-RN AgRg, Rel. Min. Eros Grau, 16.06.10.

132 STF, Rcl 390-RS, Rel. Min. Néri da Silveira, 09.11.01 
também inconstitucional. Julgando assim, o STF transmitiu ao mundo jurídico a ideia de que não considerava o efeito vinculante limitado apenas à parte dispositiva de seus julgados.

Tal decisão foi citada, inclusive, pelo Min. Maurício Corrêa em seu voto na Reclamação 1987-DF, ocasião em que o STF se utilizou da teoria da transcendência dos motivos determinantes para dar provimento ao pedido, como se demonstrará adiante.

Em outra ocasião, no julgamento da Reclamação $2291^{133}$, o relator Min. Gilmar Mendes decidiu que as razões determinantes da decisão proferida na decisão proferida na ADIn 1662 seriam aplicáveis ao caso em exame, embora não se tratasse do mesmo objeto daquela ADIn. Confira-se trecho do voto do relator:

"Observe-se, ademais, que, se entendermos que o efeito vinculante da decisão está intimamente vinculado à própria natureza da jurisdição constitucional em dado Estado democrático e à função de guardião da Constituição desempenhada pelo Tribunal, temos de admitir, igualmente, que o legislador ordinário não está impedido de atribuir essa proteção processual especial a outras decisões de controvérsias constitucionais proferidas pela Corte. Em verdade, o efeito vinculante decorre do particular papel político-institucional desempenhado pela Corte ou pelo Tribunal Constitucional, que deve zelar pela observância estrita da Constituição nos processos especiais concebidos para solver determinadas e específicas controvérsias constitucionais. Esse foi o entendimento adotado pelo Supremo Tribunal na ADC 4, ao reconhecer efeito vinculante à decisão proferida em sede de cautelar, a despeito do silêncio do texto constitucional. Não foi outro o entendimento do legislador infraconstitucional ao conferir efeito vinculante às decisões proferidas em ação direta de inconstitucionalidade.

No caso, muito embora o ato impugnado não guarde identidade absoluta com o tema central da decisão desta Corte na ADI 1.662, Relator o Min. Maurício Corrêa, vale ressaltar que o alcance do efeito vinculante das decisões não pode estar limitado à sua parte dispositiva, devendo, também, considerar os chamados fundamentos determinantes".

Com isso, o STF concedeu a cautelar para determinar a suspensão do sequestro e a imediata devolução do respectivo valor aos cofres públicos do Departamento de Trânsito do Estado do Rio de Janeiro ${ }^{134}$.

133 STF, Rcl 2291-RJ/MC, Rel. Min. Gilmar Mendes, 27.03.2003.

134 Em 12.09.04, no julgamento do mérito, o STF conheceu a Reclamação, mas julgou-a improcedente por unanimidade, cassando a liminar concedida. Entretanto, julgou dessa forma por ausência de provas, já que o ônus da prova cabia ao reclamante que não se desincumbiu de tal ônus satisfatoriamente. 
Emblemático é o acórdão exarado ao final do processo da Reclamação $1987^{\mathbf{1 3 5}}$, em 2003. Durante seu julgamento, o Plenário travou frutíferos debates acerca do tema tratado no presente trabalho.

O caso, como muitos outros, era sobre ordem de sequestro de verbas públicas por conta de mora no pagamento de precatório determinado pelo TRT, com base na EC 30/00. O Governador do Distrito Federal reclamou de tal decisão, com fulcro na decisão do Supremo na ADIn $1662^{136}$. O holding da ADIn 1662 pode ser definido no seguinte enunciado: a única hipótese que autoriza o sequestro de verbas do Poder Público é a mudança cronológica da ordem de pagamento, ou seja, a preterição do direito de precedência. Ao julgar a reclamação procedente, o STF entendeu que não só o dispositivo, mas também a fundamentação é abrangida pelo efeito vinculante.

Houve um debate na Corte. O Min. Sepúlveda disse que isso poderia transformar qualquer decisão em uma súmula vinculante, sugerindo adiamento do julgamento, pois estavam ausentes 3 Ministros. O Min. Marco Aurélio, então presidente da Corte, ressaltou que tal entendimento daria à reclamação contornos de instrumento para uniformização de jurisprudência. $\mathrm{O}$ adiamento foi acolhido. Isso ocorreu em 21.05.03.

O julgamento foi retomado em 01.10.03. O Min. Maurício Corrêa, agora Presidente do STF, disse ter havido algumas decisões de procedência de reclamação com base no desrespeito à decisão proferida na ADIn 1662, mesmo que com base em outro diploma normativo que não o impugnado na ADIn. O Min. Sepúlveda Pertence se mostrou contrário à admissibilidade da reclamação, devendo o efeito vinculante e a eficácia erga omnes se aterem ao dispositivo, tal qual a coisa julgada no Processo Civil.

O Min. Gilmar Mendes citou que foi o autor da EC 3/93, apresentada pelo Deputado Federal Roberto Campos, que trouxe o efeito vinculante ao texto constitucional. Segundo ele, a ideia de efeito vinculante tratada no 
texto constitucional sempre foi a mesma ideia do ordenamento jurídico alemão, que é a de estender o efeito vinculante aos fundamentos determinantes da decisão.

O Min. Marco Aurélio proferiu voto dizendo ser a reclamação uma medida excepcionalíssima, admitida somente nas hipóteses expressamente previstas no texto constitucional. A reclamação seria um sucedâneo recursal. Ressaltou que se se desse à reclamação esse viés de proteção de todo e qualquer julgado do STF, haveria inúmeras reclamações individuais. O STF deixaria de julgar milhares de recursos extraordinários e passaria a julgar milhares de reclamações. Substituiria um problema por outro. Como somente o dispositivo da decisão faz coisa julgada (art. 469, CPC), assim também deveria ser em relação ao efeito vinculante. Decidiu pelo não cabimento da reclamação. Se a reclamação fosse admitida pela maioria, no mérito, decidiu pela não afronta à decisão do STF na ADIn 1662.

O Min. Celso de Mello citou a Rcl 1880 AgR-SP, em que o STF decidira, com base no art.28 da Lei 9868/98, que "todos aqueles que forem atingidos por decisões contrárias ao entendimento firmado pelo STF, no julgamento do mérito proferido em ADIn, são considerados como parte legítima para a propositura da reclamação" ${ }^{137}$. Acompanhou o Presidente relator e conheceu a reclamação.

O Min. Gilmar Mendes mostrou-se favorável à teoria da transcendência dos motivos determinantes, conhecendo a reclamação. Ressaltou que "a limitação do efeito vinculante à parte dispositiva da decisão, como entende parte da doutrina, tornaria de todo despiciendo esse instituto, uma vez que ele pouco acrescentaria aos institutos da coisa julgada e da força de lei ou da eficácia erga omnes (...) tal redução diminuiria significativamente a contribuição que o Tribunal pode dar à preservação e ao desenvolvimento da ordem constitucional."

O Min. Carlos Ayres Brito também acompanhou o Presidente e conheceu a ação. 
O Min. Sepúlveda Pertence acompanhou, no mérito, o voto do Presidente.

Portanto, no final do julgamento da Reclamação 1987-DF, conheceram a reclamação os Ministros Maurício Corrêa, Nelson Jobim, Gilmar Mendes, Carlos Veloso, Joaquim Barbosa, Celso de Mello. Não a conheceram os Ministros Sepúlveda Pertence, Marco Aurélio, Carlos Ayres Britto. No mérito, julgaram a reclamação procedente os Ministros Maurício Corrêa, Nelson Jobim, Gilmar Mendes, Carlos Veloso, Joaquim Barbosa, Celso de Mello, Sepúlveda Pertence, Carlos Ayres Britto. Julgou-a improcedente o Ministro Marco Aurélio. Ausentes os Ministros Ilmar Galvão e Ellen Gracie.

Verificou-se, ao final, o acolhimento da teoria da transcendência dos motivos determinantes, uma vez que tal reclamação foi conhecida e, no mérito, acolhida com base na fundamentação de um acórdão com efeito vinculante proferido anteriormente, não com base em seu dispositivo, já que, no presente caso, tratava-se de hipótese diversa.

O STF voltou a conhecer e julgar procedentes reclamações com base na mesma decisão (ADIn 1662) em casos semelhantes, por exemplo, na Rcl 2363-PA, rel. Min. Gilmar Mendes, Brasília, no julgamento de 23.10.2003.

Posteriormente, no julgamento da Reclamação $3291^{\mathbf{1 3 8}}$, em 2005, o STF analisou o caso em que os reclamantes pleitearam o trancamento liminar de inquérito policial instaurado para investigar suposto crime de sonegação fiscal. O juiz federal, relator do caso no Tribunal Regional Federal da $3^{\text {a }}$ Região, negou a liminar requerida, sob o argumento de que a pendência de recurso administrativo sobre o crédito tributário não impede a instauração de ação penal

Eles alegaram que, ao denegar o pedido de liminar no habeas corpus referido, o juiz federal teria desrespeitado a decisão do STF na ADIn 1571, que, em síntese, assim decidiu: "antes de constituído definitivamente o crédito tributário não há justa causa para a ação penal". 
O relator, Min. Cezar Peluso, ressaltou que o efeito vinculante da decisão de Ação Direta de Inconstitucionalidade não se limita à parte dispositiva, mas se estende também aos chamados fundamentos determinantes, segundo o que se convencionou chamar de efeito transcendente dos fundamentos determinantes de decisão com efeito vinculante.

Neste caso, apesar de o STF ter julgado improcedente a reclamação, por ter entendido que o julgado do Juiz Convocado do Tribunal Regional Federal da $3^{\text {a }}$ Região não estava em dissenso com o decidido na ADIn 1571, o Tribunal se mostrou simpático à aplicação da teoria da transcendência dos motivos determinantes, como se pode verificar do excerto do voto do Ministro Relator:

"Essa visão do fenômeno da transcendência parece refletir a preocupação que a doutrina vem externando a propósito dessa específica questão, consistente no reconhecimento de que a eficácia vinculante não só concerne à parte dispositiva, mas refere-se, também, aos próprios fundamentos determinantes do julgado que o Supremo Tribunal Federal venha a proferir em sede de controle abstrato, especialmente quando consubstanciar declaração de inconstitucionalidade, como resulta claro do magistério de IVES GANDRA DA SILVA MARTINS/ GILMAR FERREIRA MENDES ("O Controle Concentrado de Constitucionalidade", p. 338/345, itens ns. 7.3.6.1 a 7.3.6.3, 2001, Saraiva) e de ALEXANDRE DE MORAES ("Constituição do Brasil Interpretada e Legislação Constitucional", p. 2.405/2.406, item n. 27.5, $2^{\mathrm{a}}$ ed., 2003, Atlas). $\mathrm{Na}$ realidade, essa preocupação, realçada pelo magistério doutrinário, tem em perspectiva um dado de insuperável relevo político-jurídico, consistente na necessidade de preservar-se, em sua integralidade, a força normativa da Constituição, que resulta da indiscutível supremacia, formal e material, de que se revestem as normas constitucionais, cuja integridade, eficácia e aplicabilidade, por isso mesmo, hão de ser valorizadas, em face de sua precedência, autoridade e grau hierárquico, como enfatiza o magistério doutrinário (ALEXANDRE DE MORAES, "Constituição do Brasil Interpretada e Legislação Constitucional", p. 109, item n. 2.8, $2^{\mathrm{a}}$ ed., 2003, Atlas).

Cabe destacar, neste ponto, tendo presente o contexto em questão, que assume papel de fundamental importância a interpretação constitucional derivada das decisões proferidas pelo Supremo Tribunal Federal, cuja função institucional, de "guarda da Constituição" (CF, art. 102, "caput"), confere-lhe o monopólio da última palavra em tema de exegese das normas positivadas no texto da Lei Fundamental, como tem sido assinalado, com particular ênfase, pela jurisprudência desta Corte Suprema: "(...) A interpretação do texto constitucional pelo STF deve ser acompanhada pelos demais Tribunais. (...) A não-observância da decisão desta Corte debilita a força normativa da Constituição. (...)." (RE 203.498-AgR/DF, Rel. Min. GILMAR MENDES)". 
Mais uma vez, ao apreciar a Reclamação $4387-$ PI $^{139}$, o STF entendeu por ser aplicável a teoria da transcendência. In casu, a decisão reclamada garantiu a um Defensor o direito de receber subsídio de Promotor. Tal ato judicial do Tribunal de Justiça do Estado do Piauí teria desrespeitado o efeito vinculante do julgado proferido na ADC 4, que vedou a concessão de equiparação vencimental através de liminar, determinando que nenhum juiz poderia conceder liminares nas hipóteses especificadas no art. $1^{\circ}$ da Lei $n^{\circ}$ 9494/97, além de também ter ferido o efeito vinculante das Ações Diretas de Inconstitucionalidade $\mathrm{n}^{\circ}$ 514/PI, 171/MG, 301/AC, 304/MA, 464/GO, 465/PB, 549/DF, 774/RS, dentre outras, que proibiram a equiparação entre espécies remuneratórias.

Assim, o ato judicial reclamado desrespeitou os fundamentos determinantes da decisão do Supremo Tribunal Federal proferida no julgamento das referidas ações diretas, precisamente porque, em tais oportunidades, o Plenário da Suprema Corte reconheceu a impossibilidade de equiparação dos vencimentos de Defensores Públicos com aqueles percebidos pelos membros do Ministério Público. Na realidade, o caso versado nos autos desta Reclamação ( $n^{\circ}$ 4387) configuraria hipótese de violação ao conteúdo essencial dos acórdãos proferidos nas aludidas ações diretas de inconstitucionalidade.

O STF decidiu dessa forma, pois entendeu que "o caráter vinculante de que se reveste seus julgamentos, em sede de fiscalização normativa abstrata, decorre não apenas do que se contém em sua parte dispositiva, mas alcança, também, em razão da transcendência de seus efeitos, os próprios fundamentos determinantes das decisões emanadas do Supremo Tribunal Federal no âmbito dos processos de controle concentrado de constitucionalidade". Dessa forma, o STF deferiu a medida liminar para suspender a eficácia da decisão reclamada.

Em outro caso, o Ministro Cezar Peluso, relator da Reclamação 
4692-RS, disse em seu voto:

"Conforme vêm se pronunciando a Corte em reiteradas oportunidades, os fundamentos ou motivos determinantes de decisão proferida no âmbito do controle concentrado e abstrato de constitucionalidade, seja em sede liminar, seja em pronunciamento definitivo, são dotados de eficácia vinculante transcendente (art. 102, § $2^{\circ}$, da CF; art. 28, § único, da Lei $n^{\circ} 9.868$, de 10.11.1999), apta a ensejar, quando violado o entendimento lá firmado por outro órgão do Poder Judiciário ou pela Administração Pública, a propositura de reclamação ao Supremo Tribunal Federal (art. 102, inc. I, "1", da CF)"140.

A partir de 2007, contudo, é possível perceber a mudança de posicionamento da Corte no julgamento de Reclamações que tratavam da teoria da transcendência dos motivos determinantes.

A primeira vez em que isso se verificou foi na Reclamação 2475$\mathbf{M G}^{\mathbf{1 4 1}}$ a Corte Suprema decidiu por negar provimento ao Agravo Regimental interposto pela União (reclamante) contra decisão que indeferira a liminar, sob argumento de que não estava presente o fumus boni iuris.

A União alegava o desrespeito à autoridade da decisão proferida na ADC $n^{\circ}$ 1-DF, que considerou ser a Lei Complementar 70/91, instituidora da COFINS, materialmente ordinária. Para a União, o voto do Min. Moreira Alves, relator da $\mathrm{ADC}$ 1, não expôs tal conceito como obter dictum, mas como fundamento determinante para se chegar à sede constitucional da COFINS, o que permitiu ao STF considerá-la constitucional. Como a decisão reclamada contrariou fundamento determinante de decisão do STF, estaria presente o requisito do fumus boni iuris.

A decisão reclamada permitia que as sociedades civis de prestação de serviços profissionais não recolhessem valor algum a título de COFINS, o que acarretaria prejuízos aos cofres públicos.

O relator da referida Reclamação, Min. Carlos Velloso, disse que o efeito vinculante só se aplica ao que foi decidido pela Corte. E o que foi decidido pela Corte é o que consta no dispositivo do voto do relator. E o 
que se tem na ementa do acórdão paradigma não é que o Tribunal decidiu que a LC 70/91 é lei complementar simplesmente sob o ponto de vista formal. Também não foi decidido que a LC 70/91 é materialmente lei ordinária. Tais pontos sequer tinham sido pedidos. Além disso não seria necessário se discutir tais pontos para decidir sobre a constitucionalidade da referida lei. No acórdão, no voto do relator, foi dito que a LC 70 é materialmente ordinária, mas tratou-se apenas de obter dictum ou de fundamento da decisão. Porém, de qualquer jeito, isto não integrou o dispositivo da decisão.

O Min. Carlos Velloso negou provimento ao agravo, após citar a decisão do Min. Moreira Alves na ADC $n^{\circ} 1$, acerca do efeito vinculante da ADC:

\begin{abstract}
"Essa decisão (e isso se restringe ao dispositivo dela, não abrangendo como sucede na Alemanha - os seus fundamentos determinantes, até porque a $\mathrm{EC} \mathrm{n}^{\circ} 3 / 93$ só atribui efeito vinculante à própria decisão definitiva de mérito), essa decisão, repito, alcança os atos normativos de igual conteúdo que deu (sic) origem a ela mas que não foi seu objeto, para o fim de, independentemente de nova ação, serem tidos como constitucionais ou inconstitucionais, adstrita essa eficácia aos atos normativos emanados dos demais órgãos do Poder Judiciário e do Poder Executivo, uma vez que ela não alcança os atos editados pelo Poder Legislativo."142
\end{abstract}

O Min. Sepúlveda Pertence, a Min. Ellen Gracie, o Min. Carlos Ayres Britto, Min. Marco Aurélio e o Min. Eros Grau acompanharam o voto do relator.

O Min. Gilmar Mendes se manteve fiel à sua posição favorável à teoria da transcendência dos motivos determinantes, ressaltando que o efeito vinculante alcança os fundamentos da decisão. Para Gilmar Mendes, a ADC 1 trouxe como fundamento da decisão o argumento de que a LC 70 era formalmente complementar e materialmente ordinária. Por isso, a decisão do STJ desobedeceu a jurisprudência do STF. Para ele, a presente reclamação deveria ser julgada procedente. Por isso, julgou procedente o agravo. Junto com ele estavam a Min. Carmen Lúcia, o Min. Joaquim 
Barbosa e o Min. Celso de Mello.

Assim, o STF não aplicou, neste caso, a teoria da transcendência dos motivos determinantes, negando provimento ao Agravo Regimental.

Da mesma forma, na Reclamação 2990-RN ${ }^{143}$, o relator, o Min. Sepúlveda Pertence, negou seguimento à reclamação por ausência de pertinência com o acórdão paradigma. O reclamante agravou e o Min. relator negou o agravo, ressaltando que, recentemente, na Rcl 2475, 02.08.07, o STF tinha rejeitado a tese da eficácia vinculante dos motivos determinantes das decisões em controle abstrato. O agravo foi negado por unanimidade.

Questão interessante foi analisada na Reclamação 6200-R $\mathbf{N}^{144}$, proposta contra julgado que supostamente desrespeitou a autoridade da decisão da Presidência do Supremo Tribunal Federal na Suspensão da Tutela Antecipada $\mathrm{n}^{\mathrm{o}}$ 229, proferida em abril de 2008. Segundo o reclamante, a decisão impugnada, ao impor restrições ao desconto dos dias não trabalhados pelos auditores fiscais federais em greve, teria violado a referida decisão (STA n $\left.{ }^{\circ} 229\right)$.

No julgamento da STA no 229, a Presidência do STF suspendeu os efeitos da decisão proferida pelo Juízo da $4^{\mathrm{a}}$ Vara Federal da Seção Judiciária do Estado do Rio Grande do Sul, que impedia a imposição de qualquer medida sancionadora ou disciplinar contra a greve dos auditores fiscais federais, inclusive para desconto de salários relativos aos dias não trabalhados. A STA n. ${ }^{\circ} 229$ tratou da greve dos auditores fiscais da Receita Federal e decidiu que é possível o desconto dos dias não trabalhados pelos servidores grevistas. Por sua vez, a decisão judicial que foi objeto desta reclamação determinou a suspensão dos descontos dos dias parados pelos mesmos servidores grevistas, havendo, nesse ponto, afronta à decisão proferida pela Presidência do STF na STA 229.

O Min. Gilmar Mendes, então Presidente do STF, destacou que a 
decisão proferida na STA n $^{\circ} 229$ não poderia ser parâmetro para a propositura de reclamação, por não ser dotada de efeito vinculante. Entretanto, a fundamentação da STA $n^{\circ} 229$ se referiu ao disposto no julgamento dos Mandados de Injunção nº 670/ES, no 708/DF e no 712/PA, que trataram da regulação provisória do exercício do direito de greve pelos servidores públicos estatutários. Assim, a despeito de a decisão na STA n ${ }^{\circ}$ 229 ter sido apontada como parâmetro da reclamação, o efetivo parâmetro de controle desta reclamação se referia ao esquema formulado naqueles julgados de mandado de injunção, que provisoriamente estabeleceram a previsão de regulação constitucional e processual da greve pelos servidores públicos estatutários. Além disso, o Min. Gilmar Mendes afirmou que o STF passou a promover significativas alterações no instituto do Mandado de Injunção, conferindo-lhe, assim, conformação mais ampla, para dotá-lo de efeito erga omnes e de efeito vinculante, por se tratar de matéria de natureza constitucional.

Foi determinada a redistribuição do processo, pois a possibilidade de o STF permitir a consideração direta dos fundamentos contidos nos mencionados mandados de injunção para a apreciação de reclamação deslocaria a competência da Presidência. O processo foi distribuído ao Ministro Cezar Peluso, que, todavia, manifestou seu entendimento no sentido de que a decisão impugnada seria efetivamente a STA n 229 , o que atrairia a competência da Presidência do STF.

A Presidência decidiu no sentido de conhecer a reclamação, considerando diretamente os fundamentos contidos nos mencionados mandados de injunção. Como a decisão reclamada contrariava o que fora decidido nos mandados de injunção citados, foi deferido o pedido liminar para suspender os efeitos da sentença proferida pela $5^{\text {a }}$ Vara Federal da Seção Judiciária do Estado do Rio Grande do Norte ${ }^{145}$.

145 A sentença tinha determinado que o Poder Público deixasse de proceder aos descontos dos dias parados nos vencimentos dos substituídos, até a instauração de processo administrativo, revestido das garantias constitucionais, observado o percentual previsto no art. $46, \S 1^{\circ}$, da Lei $n^{\circ} 8.112 / 1990$. Regra geral, os salários dos dias de paralisação não devem ser pagos, salvo no caso em que a greve tenha sido provocada justamente por atraso no pagamento 
Semelhante situação ocorreu na Reclamação 6189-MS ${ }^{146}$, que trouxe decisão do STF no mesmo sentido. Porém, na Reclamação 6207$\mathbf{A} \mathbf{M}^{147}$, apesar de a situação ser semelhante, a decisão da relatora, Min. Cármen Lúcia, foi diferente. Na espécie, a União (reclamante) requereu o deferimento de medida liminar para obter a suspensão da decisão reclamada ${ }^{148}$, que resultaria na autorização para o desconto na folha de pagamento dos dias não trabalhados pelos Auditores Fiscais da Receita Federal lotados no Estado do Amazonas. No caso, a Min. Cármen Lúcia indeferiu o pedido liminar, não adotando a teoria da transcendência dos motivos determinantes. Verifique-se parte da ementa da decisão:

"Apesar de o nobre Ministro Presidente sugerir a possibilidade de se reconhecer 'causa de pedir aberta nas reclamações', com a consequente adoção da teoria dos fundamentos determinantes, entendo que a ponderação de interesses de ambas as partes exige um estudo cuidadoso da matéria pelo órgão plenário do Supremo Tribunal, já que resultaria em importante alteração dos contornos que atualmente prevalecem no processamento e julgamento das reclamações constitucionais. Acrescentese a isso a circunstância de a União dispor de outros instrumentos jurídicos para reaver dos servidores grevistas o que eventualmente for pago indevidamente. Pelo exposto, sem prejuízo de reapreciação da matéria no julgamento do mérito, indefiro o pedido de medida liminar."

Apesar de o tema se restringir ao controle concentrado de constitucionalidade, o STF também se valeu da teoria em outros julgados

ou por outras situações excepcionais que justifiquem o afastamento da premissa da suspensão do contrato de trabalho. Na espécie, a decisão reclamada impôs a exigência de prévia instauração de procedimento administrativo individualizado, como condição ao desconto. Tal determinação violou a regra geral de suspensão do contrato de trabalho no exercício do direito de greve, pois a inexistência de prestação de serviço corresponde, em princípio, à desobrigação de pagamento de salários. Assim, quando o Poder Público comprova a inexistência de prestação de serviço por parte do servidor grevista num determinado período, não há óbice para o desconto, de imediato, dos dias não trabalhados. Esse entendimento decorre do disposto naqueles julgados de mandado de injunção ( $n^{\circ}$ 670/ES, $n^{\circ}$ 708/DF e $n^{\circ}$ 712/PA), que provisoriamente estabeleceram a previsão de regulação constitucional e processual da greve pelos servidores públicos estatutários. O STF chegou a afirmar que a adesão a um movimento grevista pressupõe riscos em relação à sua legitimidade e à sua legalidade. Dessa forma, ao aderir à greve, o servidor público tem que assumir os ônus financeiros dos dias não trabalhados. Conhecida a reclamação, o Presidente do Supremo deferiu o pedido liminar parcialmente, suspendendo a decisão nos autos do mandado de segurança coletivo $\mathrm{n}^{\circ}$ 2008.84.00.003288-9, tão somente quanto à exigência de prévia instauração e finalização de processo administrativo, como condição ao desconto dos dias não trabalhados.

146 STF, Rcl 6189 MC-MS, Rel. Min. Gilmar Mendes, 23.09.08.

147 STF, Rcl 6207 MC-AM, rel. min. Cármen Lúcia, Brasília, 28.02.2009.

148 Decisão proferida nos autos do Mandado de Segurança n ${ }^{\circ}$ 2008.32.00.002332-9 pelo juízo da $1^{\text {a }}$ Vara Federal de Manaus/AM. 
que não possuem efeito vinculante previsto expressamente. Nesse sentido, o STF tem admitido o julgamento monocrático de recursos extraordinários baseados na exegese firmada em acórdãos anteriores. Por exemplo, no RE 228.844-SP ${ }^{149}$ o Min. Maurício Corrêa decidiu pela inconstitucionalidade do IPTU progressivo cobrado pelo Município de São José do Rio Preto/SP, com base em precedente no mesmo sentido em relação ao Município de Belo Horizonte/MG. No RE 364.160-MG ${ }^{150}$ a Min. Ellen Gracie declarou a inconstitucional da instituição de taxa de iluminação pública pelo Município de Cabo Verde/MG, partindo do precedente no mesmo sentido do Município de Niterói/RJ.

O STF também tem dado essa relevância às normas que se extraem de seus julgados em relação às súmulas, uma vez que muitas súmulas são editadas após a análise de casos locais. Um exemplo é o caso do Enunciado 670 ${ }^{151}$, que surgiu de julgados referentes a leis dos Municípios de Niterói/RJ e Ivoti/RS. Também o Enunciado $681^{152}$ foi editado após julgados dos Estados de Rondônia, Tocantins, Santa Catarina e do Município do Rio de Janeiro.

Portanto, verifica-se que a jurisprudência do STF tem sido vacilante quanto ao tema. A aceitação de Reclamação com base na teoria da transcendência dos motivos determinantes era mais frequente no início da década, porém, atualmente, percebe-se uma mudança nesse posicionamento. Nas últimas vezes em que tratou do tema, o Supremo não utilizou a teoria, afirmando, em alguns casos, inclusive, seu refutamento pela maioria dos Ministros $^{153}$.

149 STF, RE 228.844-SP, Rel. Min. Maurício Corrêa, 26.06.99.

150 STF, RE 364.160-MG, Rel. Min. Ellen Gracie, 07.02.03.

151 Enunciado 670 da súmula da jurisprudência dominante do STF: "o serviço de iluminação pública não pode ser remunerado mediante taxa".

152 Enunciado 681 da súmula da jurisprudência dominante do STF: "é inconstitucional a vinculação do reajuste de vencimentos de servidores estaduais ou municipais a índices federais de correção monetária".

153 STF, Rcl 3014-SP, Rel. Min. Ayres Britto, 10.03.10; STF, Rcl 4875-SP AgRg, Rel. Min. Eros Grau, 17.06.10; STF, Rcl 6204-AL AgRg, Rel. Min. Eros Grau, 06.05.10; STF, Rcl 6319SC AgRg, Rel. Min. Eros Grau, 17.06.10; STF, Rcl 8175-RN AgRg, Rel. Min. Eros Grau, 16.06.10. 


\section{Aplicação da teoria por outros Tribunais Superiores:}

Atualmente, percebe-se uma tendência em se impor o efeito vinculante às decisões proferidas pelos órgãos superiores do Judiciário.

Pode-se perceber, ainda que timidamente, relances dessa tendência nas últimas reformas do CPC. Um exemplo é a decisão de recursos representativos de controvérsia (CPC, art. 543-B), em que a decisão tomada pelo STF tem um efeito muito semelhante ao efeito vinculante, uma vez que se os Tribunais proferirem decisão contrária ao entendimento firmado pelo Supremo, este poderá cassar ou reformar liminarmente tal decisão, por ocasião do julgamento do recurso extraordinário (art. 543-B, $\S 4^{\circ}$ ). Isso se assemelha à previsão do CPC em relação aos recursos especiais ao STJ (CPC, art. 543-C).

Tais mudanças são imprescindíveis e adequadas para a resolução do problema das causas de massa ${ }^{154}$. Juntamente com esses instrumentos poder-se-ia aplicar a teoria da transcendência dos motivos determinantes, como forma de fazer com que os fundamentos das decisões dos Tribunais Superiores fossem observados pelas instâncias inferiores do Poder Judiciário. Isso faria aumentar a importância dos precedentes judiciais no Direito brasileiro.

O Judiciário, como qualquer órgão do Poder Público, atua de acordo com a reserva do possível. Tem-se observado, ultimamente, o crescente acesso da população em geral ao Judiciário para a resolução de litígios. Isso é comum numa sociedade complexa que reúne diversas relações de troca ${ }^{155}$. Porém, o ritmo acelerado de crescimento das causas julgadas pelos

154 As causas de massa são causas com o mesmo fundamento jurídico, baseada em situações semelhantes que ocorrem com pessoas distintas. É comum, por exemplo, em causas consumeristas ou tributárias. $\mathrm{O}$ ato de uma empresa pode afetar milhões de consumidores ao mesmo tempo. Cada consumidor individualmente considerado tem o direito constitucional de ingressar em juízo para ver sua causa decidida e obter um provimento jurisdicional que lhe garanta seus direitos. Porém, o Judiciário não pode continuar a analisar cada uma dessas causas individualmente, sob risco de lesão à celeridade processual $\left(\mathrm{CF}\right.$, art. $\left.5^{\circ}, \mathrm{LXXVIII}\right)$, à prestação jurisdicional efetiva e ao princípio da isonomia $\left(\mathrm{CF}\right.$, art. $5^{\circ}$, caput $)$.

155 GIL, José. Justiça. In: Enciclopédia Einaudi, volume 39. Porto: Imprensa Oficial - Casa da Moeda, 1984, p. 228. 
Tribunais Superiores aliado ao diminuto número de Ministros prejudica o atendimento jurisdicional à sociedade.

Por isso, não seria ruim pensar em um instrumento que exercesse um caráter vinculante quanto aos órgãos de graus inferiores integrantes dos diversos ramos da Justiça. Assim, decisões do STJ teriam caráter vinculante sobre os demais órgãos da Justiça Comum (Justiça Federal e Justiça Estadual), o mesmo ocorrendo em relação ao TST e os órgãos da Justiça Trabalhista, ao TSE e os órgãos da Justiça Eleitoral e ao STM e os órgãos da Justiça Militar.

Isso talvez seja mais facilmente concebível em relação ao Superior Tribunal de Justiça. Como se sabe, a Constituição Federal de 1988 colocou o STJ como o guardião da legislação federal, em substituição ao STF, que tinha esta função antigamente. Além disso, a legislação infraconstitucional $^{156}$, por diversas vezes, revela um paralelo entre a situação de ambas as Cortes.

Entretanto, como visto, não se pode afirmar que as decisões dos Tribunais Superiores têm efeito vinculante ou eficácia erga omnes. Apesar das diversas semelhanças entre o STF e o STJ, nada leva a crer que seja da vontade do Constituinte ou do legislador ordinário a atribuição de efeito vinculante às decisões do STJ ou de qualquer outro Tribunal Superior. Tal efeito só pode ser concedido pela Constituição ou pela lei, que devem fazêlo de forma explícita.

Como visto, a teoria da transcendência dos motivos determinantes é baseada no efeito vinculante conferido por razões singulares aos processos objetivos de controle abstrato de constitucionalidade. Não seria oportuno, portanto, imaginar sua aplicação em esferas judiciais que não tenham competência para julgar processos semelhantes. Talvez, se houvesse um instrumento processual capaz de levar a análise da aplicação de uma lei

156 Por exemplo, o CPC trata das competências recursais do STF e do STJ em uma mesma seção, além de prever o julgamento similar de recursos que tratem da mesma matéria (art. 543B e art. 543-C). Por sua vez, a Lei 8.038 de 28.05.1990 trata em conjunto dos processos perante o STJ e o STF. 
federal ao STJ em um procedimento objetivo e a lei dotasse a decisão tomada pelo Superior de efeito vinculante, seria possível tratar da hipótese.

Dessa forma, não se pode pensar em aplicação da teoria antes de se conferir caráter vinculante e eficácia erga omnes às decisões dos Tribunais Superiores, uma vez que a teoria é um plus em relação a esses efeitos, tendo caráter simplesmente acessório.

Apedar disso, a tendência de reunir causas de massa para julgamento único pode vir a dotar as decisões das Cortes Superiores, no futuro, com o efeito vinculante, no âmbito de sua jurisdição. Ocorrendo isso, não seria incoerente ou extremo falar na aplicação da teoria da eficácia transcendente dos fundamentos às decisões dos Tribunais Superiores.

Entretanto, há circunstâncias prévias a serem discutidas e minuciosamente analisadas. Por exemplo, o instrumento para a efetivação desse processo deve estar previsto expressamente na lei, seja a reclamação, que a Constituição só confere ao $\mathrm{STJ}^{157}$, além do STF, seja uma forma simplificada de julgamento de recursos representativos de controvérsia, que o CPC, da mesma forma, só prevê em relação a alguns recursos julgados pelo STF e pelo STJ.

De fato, é percebível a previsão do instrumento da Reclamação, ainda, em outros Tribunais. Por exemplo, na Justiça Trabalhista, o Regimento Interno do TST prevê a Reclamação e seu rito nos arts. 190 a 194. Na Justiça Eleitoral, o Regimento Interno do TSE prevê a Reclamação no art. 15, além de trazer a aplicação subsidiária do Regimento Interno do STF, no art. 94. Na Justiça Militar, podemos citar a Lei 8.457/1992, art. $6^{\circ}$, I, “f”, além do Regimento Interno do STM, arts. 105 a 107. Por fim, na Justiça Comum Estadual, podemos trazer o exemplo do Tribunal de Justiça da Bahia, com previsão em seu Regimento Interno, art. 59, XXXVI, “j”, o Tribunal de Justiça de São Paulo, que prevê o instrumento em seu Regimento Interno, arts. 659 a 666, e o já citado Tribunal de Justiça do Ceará, que trata da matéria em seu Regimento Interno, art. 21, VI, “j”. 
Isso se tornou ainda mais relevante após a decisão do $\mathrm{STF}^{158}$ que julgou constitucional a previsão da via reclamatória em âmbito estadual.

De qualquer forma, nos moldes do Direito brasileiro atual, seria um equívoco afirmar que tanto o efeito vinculante quanto a teoria da transcendência dos motivos determinantes, que trata simplesmente do modus operandi da aplicação do próprio efeito vinculante, poderiam ser utilizados em outros processos ou em outros Tribunais que não sejam os processos objetivos de controle concentrado abstrato de constitucionalidade decididos pelo Supremo Tribunal Federal. 


\section{Conclusão}

O Direito brasileiro aos poucos tem começado a trabalhar com os precedentes judiciais como peças elementares do ordenamento jurídico. Apesar de o Brasil não ter a cultura dos precedentes, estes têm sido cada vez mais valorizados pela lei, pela Constituição Federal, pela doutrina e pela própria jurisprudência, como se mostrou ao longo deste trabalho.

$\mathrm{O}$ aumento da importância da jurisprudência como fonte de direito aliado ao caráter vinculante de certas decisões do Judiciário traz a necessidade de definição de algumas questões. A utilização dos julgados na construção do Direito não é tarefa fácil e faz emergir perguntas que precisam de respostas.

Uma destas é acerca da forma como se produzirão o efeito vinculante e a eficácia erga omnes nas do STF em sede de ADIn e ADC. Deve-se delimitar precisamente o âmbito de abrangência desses efeitos, tendo em vista a complexidade das "decisões definitivas de mérito, proferidas pelo Supremo Tribunal Federal"159. A qual parte da decisão está se referindo a Constituição Federal?

A teoria da transcendência dos motivos determinantes busca responder tal indagação, que se mostra crucial para que se trabalhe com os precedentes judiciais no Brasil. Pela teoria, defende-se que a vinculação do precedente alcança os fundamentos da decisão, juntamente com o seu dispositivo. Por isso, a aceitação da aplicação da teoria representaria para o Direito brasileiro uma forma mais inteligente de lidar com a normatividade dos precedentes judiciais, pois se buscaria extrair da decisão um holding, ou seja, uma norma utilizada pelo Tribunal para decidir o caso que analisou. Por outro lado, a rejeição da teoria poderia inviabilizar a plena vinculação dos casos semelhantes posteriores aos precedentes, dificultando o desenvolvimento da jurisprudência como fonte do direito.

Com efeito, não é apenas por causa do caráter vinculante dos precedentes do Supremo em controle concentrado de constitucionalidade 
que a aplicação da teoria é defendida. Na verdade, o bom uso dos precedentes judiciais serviria para a efetivação de uma série de princípios constitucionais que embasam a própria ideia de força normativa dos precedentes. Entre eles está o princípio da isonomia, pelo qual todos os jurisdicionados devem receber o mesmo tratamento do Judiciário. Também o princípio da segurança jurídica, pelo qual os cidadãos devem ter a oportunidade de conhecer seus diretos e a forma de aplicação das leis e demais atos normativos pelo Poder Público. Outro princípio constitucional relevante ao tema é o princípio da celeridade processual, pelo qual todos os jurisdicionados devem receber a tutela judicial em tempo hábil, sem demoras indevidas.

Entretanto, para a aplicação da teoria da transcendência dos motivos determinantes existem alguns obstáculos tanto de caráter político, quanto de caráter formal. Um obstáculo político seria a concentração de poderes no Supremo Tribunal Federal, órgão de cúpula do Poder Judiciário, cujos membros não são escolhidos mediante processo eleitoral. O aumento de poderes do Judiciário poderia significar um processo não democrático, já que o povo não escolhe diretamente seus juízes.

Além disso, surgem também algumas dificuldades de caráter formal, como a não publicação dos fundamentos das decisões, a falta de contagem dos votos em relação aos motivos determinantes e a longa extensão dos votos proferidos por cada Ministro do Supremo.

Essas são barreiras que devem ser vencidas antes da implementação da teoria da transcendência dos motivos determinantes no Direito brasileiro, para a instauração de uma cultura jurídica que leva a sério o papel dos precedentes vinculantes.

O fato de o Brasil ainda dar os seus primeiros passos neste rumo torna imprescindível a adoção de técnicas e conceitos do direito comparado, pautando-se principalmente em institutos que funcionaram em países como os Estados Unidos e a Alemanha. A vinculação da norma emergente do precedente, numa análise em conjunto do dispositivo com os seus 
fundamentos determinantes, é uma das características relevantes desses países na tentativa de se trabalhar com o conceito de efeito vinculante.

A jurisprudência do Supremo, assim que se deparou com a possibilidade de estender a abrangência do efeito vinculante aos fundamentos da decisão, mostrou-se favorável a esta ideia. Em algumas Reclamações, como visto ao longo deste trabalho, o STF adotou explicitamente a teoria da transcendência dos motivos determinantes para julgar. Entretanto, mais recentemente, a Corte Suprema mudou o seu entendimento, passando a rechaçar peremptoriamente a teoria.

Com idas e vindas na jurisprudência do $\mathrm{STF}^{160}$, com grandes debates doutrinários, tendo fortes juristas se posicionando a favor ${ }^{161}$ da adoção da teoria e outros, igualmente brilhantes, posicionando-se contrariamente ${ }^{162}$ a ela, a teoria da eficácia transcendente dos motivos determinantes demonstra toda a profundidade e a riqueza do Direito Constitucional brasileiro, muitas vezes escondidas em suas entrelinhas. O futuro do Direito Constitucional, principalmente em relação à vinculação dos precedentes, passa por aqui. E torna-se essencial ao seu desenvolvimento que doutrina e jurisprudência achem soluções adequadas aos novos desafios que se colocam à sua frente.

160 STF, Rcl 3014-SP, Rel. Min. Ayres Britto, 10.03.10.

161 MELLO, Patrícia Perrone Campos. Precedentes - O desenvolvimento judicial do direito no constitucionalismo contemporâneo. Rio de Janeiro: Renovar, 2008.

162 FERNANDES, André Dias. Eficácia das decisões do STF em ADIN e ADC. Efeito vinculante, coisa julgada erga omnes e eficácia erga omnes. Salvador: Jus Podivm, 2009. 


\section{Bibliografia}

ALEXY, Robert. Teoria da argumentação jurídica. Trad. Zilda Hutchinson. São Paulo: Landy, 2001. 355p.

ÁVILA, Humberto. Teoria dos Princípios: da definição à aplicação dos princípios jurídicos. $4^{\mathrm{a}}$ edição. São Paulo: Malheiros, 2004. 176 p.

BARROSO, Luís Roberto (org.). A Nova Interpretação Constitucional: ponderação, direitos fundamentais e relações privadas. $2^{a}$ edção. Rio de Janeiro: Renovar, 2006. 419 p.

O controle de constitucionalidade no direito brasileiro: exposição sistemática da doutrina e análise crítica da jurisprudência. $2^{a}$ edição, revista e atualizada. São Paulo: Saraiva, 2007. 333 p.

BUZAID, Alfredo. Correição parcial - recursos processuais reresentação. Revista Forense, $\mathrm{n}^{\mathrm{o}}$ 175, pp. 90-97. Rio de Janeiro: Forense, 1958.

CLÈVE, Clèmerson Merlin. A fiscalização abstrata de constitucionalidade no direito brasileiro. $2^{\text {a }}$ edição. São Paulo: Revista dos Tribunais, 2000. $484 \mathrm{p}$.

CUNHA, Leonardo José Carneiro da. Natureza Jurídica da Reclamação Constitucional. In: NERY JR., Nelson, WAMBIER, Teresa Arruda Alvim (coordenadores). Aspectos polêmicos e atuais dos recursos cíveis e de outros meios de impugnação às decisões judiciais. São Paulo: Revista dos Tribunais, 2005. p. 325-341.

DINAMARCO, Cândido Rangel. A reclamação no processo civil brasileiro. In: NERY JR., Nelson, WAMBIER, Teresa Arruda Alvim (coordenadores). Aspectos polêmicos e atuais dos recursos cíveis e de outros meios de impugnação às decisões judiciais, volume 6. São Paulo: Revista dos Tribunais, 2002. 570 p.

FERNANDES, André Dias. Eficácia das decisões do STF em ADIN e ADC. Efeito vinculante, coisa julgada erga omnes e eficácia erga omnes. 
Salvador: Jus Podivm, 2009. 313 p.

FERRARI, Regina M. M. Nery. Efeitos da declaração de inconstitucionalidade. $4^{\mathrm{a}}$ edição. São Paulo: Revista dos Tribunais, 1999. $286 \mathrm{p}$.

FILHO, José dos Santos Carvalho. Manual de Direito Administrativo, 21 ${ }^{\mathrm{a}}$ edição, Rio de Janeiro: Lumen Juris, 2009. 1.177 p.

FUX, Luiz. Curso de direito processual civil. Rio de Janeiro: Forense, 2001. 1859 p.

GIL, José. Justiça. In: Enciclopédia Einaudi, volume 39. Porto: Imprensa Oficial - Casa da Moeda, 1984. 257 p.

GÓES, Gisele Santos Fernandes. A Reclamação Constitucional. In: NERY JR., Nelson, WAMBIER, Teresa Arruda Alvim (coordenadores). Aspectos polêmicos e atuais dos recursos cíveis e de outros meios de impugnação às decisões judiciais. São Paulo: Revista dos Tribunais, 2005. p. 123-145.

GRECO, Leonardo. Instituições de Processo Civil, volume 1. Rio de Janeiro: Forense, 2010. 579 p.

JÚNIOR, Humberto Teodoro. Curso de Direito Processual Civil, vol. 1 Teoria gera do direito processual civil e processo de conhecimento. $50^{\mathrm{a}}$ edição. Rio de Janeiro: Forense, 2009. 790 p.

JÚNIOR, Tércio Sampaio Ferraz, Introdução ao Estudo do Direito, $4^{\mathrm{a}}$ edição. São Paulo: Atlas, 2003. 370 p.

LIEBMAN, Enrico Tulio. Eficácia e autoridade da sentença. $3^{\mathrm{a}}$ edição brasileira. Trad.: Ada Pellegrini Grinover, Alfredo Buzaid e Benvindo Aires. Rio de Janeiro: Forense, 1984, 332 p.

LIMA, Alcides de Mendonça. O Poder Judiciário e a nova Constituição. Rio de Janeiro: Aide, 1989. 164 p.

MARQUES, José Frederico. Instituições de Direito Processual Civil, vol. IV, $2^{a}$ edição. Rio de Janeiro: Forense, 1972. 397 p. . Manual de direito processual civil, volume 3. Atualizado por Vanilson Rodrigues Alves. Campinas: Bookseller, 1997. 285 p. 
MARTINS, Ives Gandra; MENDES, Gilmar Ferreira. Controle Concentrado de Constitucionalidade: comentários à Lei no 9.868, de 1011-1999. São Paulo: Saraiva, 2001. 583 p.

MELlO, Patrícia Perrone Campos. Precedentes - O desenvolvimento judicial do direito no constitucionalismo contemporâneo. Rio de Janeiro: Renovar, 2008. 348 p.

MENDES, Gilmar Ferreira. Controle de constitucionalidade: aspectos jurídicos e políticos. São Paulo: Saraiva, 1990. 371 p.

; COELHO, Inocêncio Mártires; BRANCO, Paulo Gustavo Gonet.

Curso de direito constitucional, $2^{\mathrm{a}}$ edição, revista e atualizada. São Paulo: Saraiva, 2008. 1.432 p.

O efeito vinculante das decisões do Supremo Tribunal Federal nos processos de controle abstrato de normas. Revista Jurídica Virtual.Brasília, vol. 1, n. 4, agosto 1999.

MORAES, Alexandre de. Constituição do Brasil Interpretada e Legislação Constitucional, 2a edição. São Paulo: Atlas, 2003. 2.922 p.

MORATO, Leonardo Lins. A reclamação prevista na Constituição Federal. In: ARRUDA ALVIM, Eduardo Pelegrini de; NERY JUNIOR, Nelson; WAMBIER, Teresa Arruda Alvim (Coord.). Aspectos polêmicos dos recursos e de outros meios de impugnação às decisões judiciais. São Paulo: Revista dos Tribunais, 2000. 706 p.

MOREIRA, José Carlos Barbosa. Comentários ao Código de Processo Civil, v. 5. $11^{\mathrm{a}}$ edição. Rio de Janeiro: Forense, 2003. 691 p.

NERY JUNIOR, Nelson. Princípios fundamentais: teoria geral dos recursos. $3^{\mathrm{a}}$ ed. São Paulo: Revista dos Tribunais, 1996. 533 p.

; NERY, Rosa Maria de Andrade. CPC comentado. $5^{\text {a }}$ ed. São Pulo: Revista dos Tribunais, 2001. 1855 p.

; Teresa Arruda Alvim (coordenadores). Aspectos polêmicos e atuais dos recursos cíveis e de outros meios de impugnação às decisões judiciais, volume 8. São Paulo: Revista dos Tribunais, 2005. 792 p.

OLIVEIRA, Rafael Carvalho Rezende. A constitucionalização do Direito 
Administrativo: o princípio da juridicidade, a releitura da legalidade administrativa e a legitimidade das agências reguladoras. Rio de Janeiro: Lumen Juris, 2010. 198 p.

REALE, Miguel, Lições Preliminares de Direito, $27^{\mathrm{a}}$ edição. São Paulo: Saraiva, 2002. $391 \mathrm{p}$.

SILVA, Celso de Albuquerque. Do efeito vinculante: sua legitimação e aplicação. Rio de Janeiro: Lumen Juris, 2005. 319 p.

TUCCI, José Rogério Cruz e. Precedente Judicial como Fonte do Direito. São Paulo: Revista dos Tribunais, 2004.

VIEIRA, Oscar Vilhena. Supremo Tribunal Federal: Jurisprudência Política, $2^{\mathrm{a}}$ edição. São Paulo: Malheiros, 2002. 